\title{
MODULE 3
}

\section{Biomass}

Open Educational Resources for online course of renewable energy for local development

Coordinator: Leonor Hernández

Authors: Zsolt Radics and Csaba Patkós

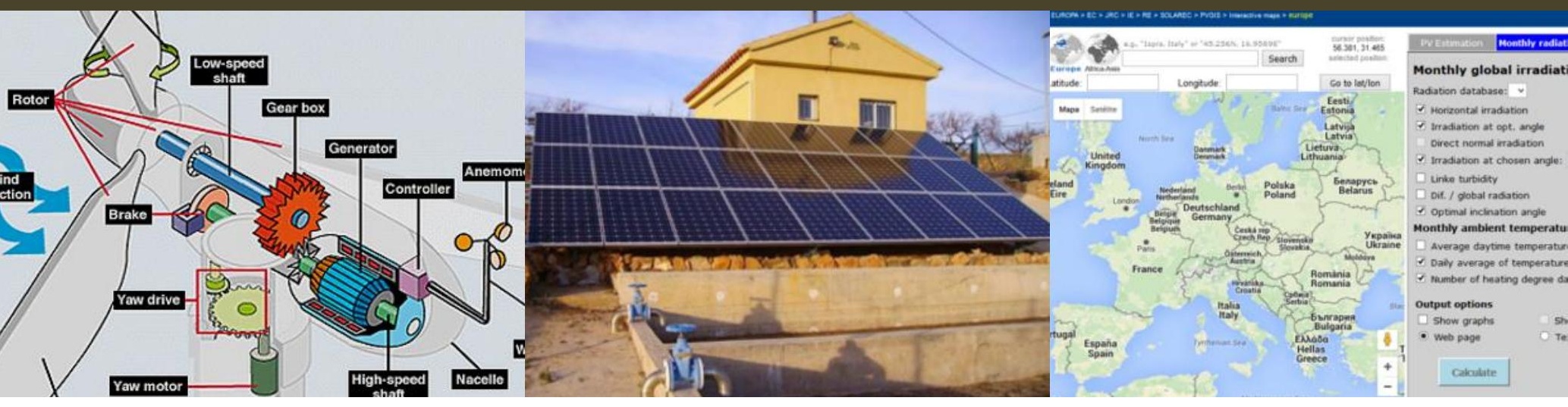

* inzRural

Co-funded by the

Erasmus+ Programme

of the European Union

回

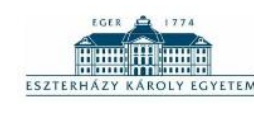

Universitatea
"Vasile Alecsandri"
din Bacau

$4 \mathrm{mans}$ 
Place and year of edition:

Gyöngyös (Hungary), 2016

Coordinator:

Leonor Hernández

Authors:

Zsolt Radics

CsabaPatkós

CC BY-NC-SA

This licence allows others remix, transform, or build upon the material without commercial purposes, giving appropriate credit and distributing their contributions under the same license as the original.

DOI: http://dx.doi.org/10.6035/IN2RURAL.2016.11

The PDF version of this document is available in:

http://in2rural.ub.ro/, http://in2rural.uji.es/ and http://repositori.uji.es/xmlui/handle/10234/154485

The European Commission support for the production of this publication does not constitute an endorsement of the contents which reflects the views only of the authors, and the Commission cannot be held responsible for any use which may be made of the information contained therein. 


\section{TABLE OF CONTENTS}

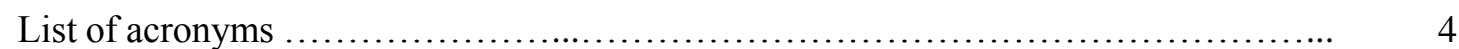

CHAPTER 1. TECHNICAL ASPECTS ................................... 6

Subchapter 1.1 - Principles concerning the use of biomass energy. Conditions for 6 efficient exploitation

Subchapter 1.2 - Technical alternatives and installation types for 'biomass' installations applicable for rural development

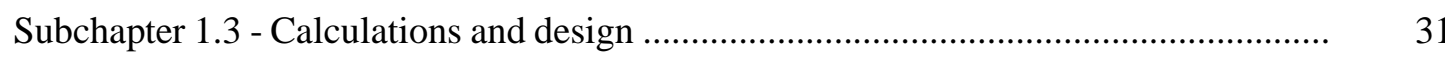

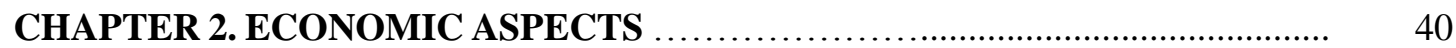

Subchapter 2.1 - Estimation cost of the investment (materials, installations, spatial 40 planning)

Subchapter 2.2 - Other costs (employment, management, maintenance, etc.)

Subchapter 2.3 - Analysis of economic efficiency and profitability

CHAPTER 3. SOCIAL AND ENVIRONMENTAL ASPECTS FOR RURAL DEVELOPMENT

Subchapter 3.1 - Assessment of environmental impact. Emissions and Life Cycle Analysis

Subchapter 3.2 - Social and Rural Development impact ........................... 77

Subchapter 3.3 - Vision for future. Ideas and new suggestions for future ............... 81

CHAPTER 4. FULLY DEVELOPED CASE STUDY .............................. 88

Subchapter 4.1 - Introduction ............................................... 89

Subchapter 4.2 - Technical aspects of the case study .............................. 89

Subchapter 4.3 - Calculations and design ...................................... 91

Subchapter 4.4 - Financial considerations ..................................... 98

Subchapter 4.5 - Environmental, social and rural impact of the case study development . 101

Subchapter 4.6 - Conclusions ............................................ 103

Subchapter 4.7 -References ..................................................... 103

CHAPTER 5. PROPOSED CASE STUDIES .................................. 104

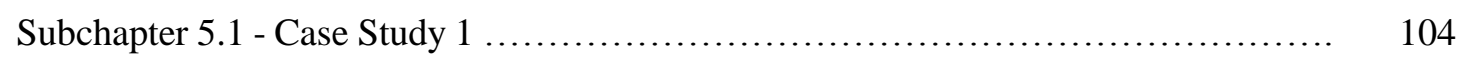

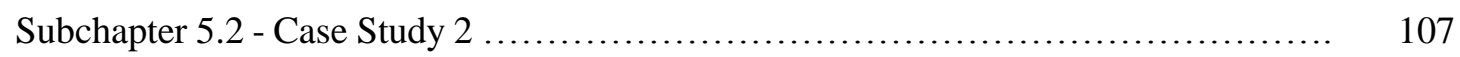

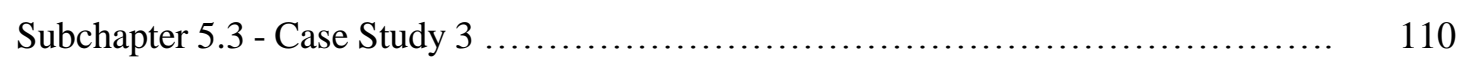

Subchapter 5.4 - Case Study 4 ................................................. 113

Subchapter 5.5 - Case Study 5 ............................................... 116

Subchapter 5.6 - Case Study 6 ............................................... 119

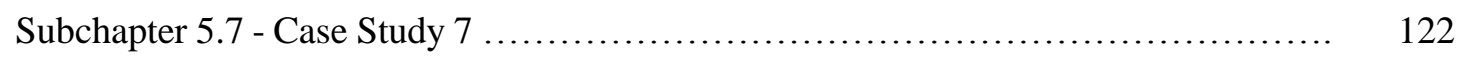

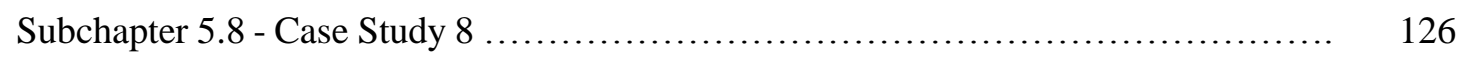

Subchapter 5.9 - Case Study 9 .............................................. 129

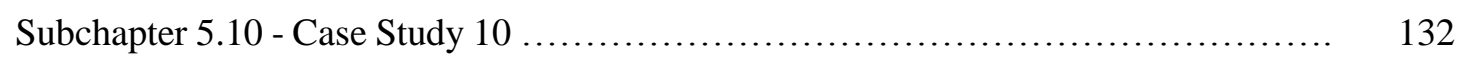


MODULE 3: BIOMASS

CHAPTER 6. Extra material

Subchapter 6.1.: List of Acronyms.

Dr. Zsolt Radics

Geolin Co., Hungary

\section{List of Acronyms}

Anaerobic digestion (AD)

Annualized rate of return (ARR)

Associative forest management community (AFMC)

Available biomass supply (ABS)

Bubbling fluidized beds (BFB)

Capital expenditure (CAPEX or CapEx)

Circulating fluidized beds (CFB)

Co-combustion (CO-COMB)

Combined heat and power (CHP)

Direct combustion (COMB)

Earnings Before Interest and Tax (EBIT)

Economic Value Added (EVA)

Energy payback time (EPBT)

European Center for Renewable Energy (EEE)

Fatty acid methyl ester (FAME)

Federal Ministry for Transport, Innovation and Technology, Austria (BMVIT)

Fischer-Tropsch synthesis (FT synthesis)

Flex fuel vehicles (FFVs)

Fluidized bed combustion (FBC)

Gasification (IBGCC)

Greenhouse gas (GHG)

Güssing Renewable Energy (GREG)

Heat (HE)

Hydrothermal upgrading (HTU)

Internal rate of return (IRR)

International Renewable Energy Agency (IRENA) 
Kilograms of oil equivalent $(\mathrm{kgOE})$

Kilowatt-electric (kWe) (One thousand watts of electric capacity)

Levelized cost of electricity (LCOE)

Levelized Energy Cost (LEC)

Life Cycle Assessment (LCA)

Liquid fuels (LF)

Megawatts of thermal capacity $\left(\mathrm{MW}_{\text {th }}\right)$

Net Operating Profit After Taxes (NOPAT)

No commercial value (NCV)

ökoEnergieland (öEL)

Operation and maintenance (O\&M)

Organic Rankine cycle (ORC)

Payback time (PBT)

Petajoule (PJ)

Polychlorinated dibenzo-p-dioxins and dibenzofurans (PCDD/DFs)

Polycyclic Aromatic Hydrocarbon (PAC)

Potential biomass supply (PBS)

Qualified Zone Academy Bond (QZAB)

Research and development (R\&D)

Return on Assets (ROA)

Return On Capital Employed (ROCE)

Return On Investment (ROI)

Straight vegetable oil (SVO)

Substitute natural gas (SNG)

Supply Chain Management (SCM)

Sustainability biomass supply (SBS)

Total Organic Carbon (TOC)

Toxic equivalency factor (TEF)

United States Department of Energy (US DOE)

Value added tax (VAT)

Waste vegetable oil (WVO) 


\title{
MODULE 3: BIOMASS
}

CHAPTER 1. Technical aspects. Subchapter 1.1.: Principles concerning the use of biomass energy. Conditions for efficient
exploitation.

\author{
Dr. Zsolt Radics \\ Geolin Co., Hungary
}

\begin{abstract}
Summary: The chapter gives an introduction to the main concepts of biomass. The students get familiar with the categories of biomass materials and the principles of biomass utilization. The chapter also gives a detailed analysis about the utilization of biomass, the technical alternatives and installation types of biomass power plant. By acquiring the material of the subchapter, the students get familiar with the concepts concerned with biomass, the principles of biomass energy utilization, the status of biomass in Europe and the conditions for efficient exploitation.
\end{abstract}

\subsubsection{Concepts of biomass}

A number of definitions have been created regarding the term 'biomass'. First, from an ecological approach, biomass is the amount of living matter in a given habitat, expressed either as the weight of organisms per unit area or as the volume of organisms per unit volume of habitat. However, in this material, the energetic approach is highlighted, according to which biomass is an organic matter, especially plant matter that can be converted to fuel and it is therefore regarded as a potential energy source. Concerning the above mentioned statement, the term of biomass refers to an energy source and also refers to plants or plant-based materials which are not used for food or feed, and are specifically called lignocellulosic biomass.

Biomass is carbon based and is composed of a mixture of organic molecules containing hydrogen, usually including atoms of oxygen, often nitrogen and also small quantities of other atoms, including alkali, alkaline earth and heavy metals. These metals are often found in functional molecules such as the porphyrins which include chlorophyll that contains magnesium.

The carbon used to construct biomass is absorbed from the atmosphere as carbon dioxide $\left(\mathrm{CO}_{2}\right)$ during the life of the plant, using energy from the sun. Plants may subsequently be eaten by animals and thus converted into animal biomass. However, the primary $\mathrm{CO}_{2}$ absorption is performed by plants. Then, if plant material is not eaten it is generally either broken down by micro-organisms or burned:

- If broken down it releases the carbon back to the atmosphere, mainly as either carbon dioxide $\left(\mathrm{CO}_{2}\right)$ or methane $\left(\mathrm{CH}_{4}\right)$, depending on the conditions and processes involved.

- If burned the carbon is returned to the atmosphere as $\mathrm{CO}_{2}$.

These processes have happened for as long as there have been plants on Earth and they are part of what is known as the carbon cycle. 
The vital difference between biomass and fossil fuels is one of time scale. Biomass takes carbon out of the atmosphere while it is growing, and returns it as it is burned. If it is managed on a sustainable basis, biomass is harvested as part of a constantly replenished crop. This is either during woodland or arboricultural management or coppicing or as part of a continuous programme of replanting with the new growth taking up $\mathrm{CO}_{2}$ from the atmosphere at the same time as it is released by combustion of the previous harvest. This maintains a closed carbon cycle with no net increase in atmospheric $\mathrm{CO}_{2}$ levels.

Features of biomass as energy source:

- Its renewal is possible due to photosynthesis

- The storage of energy is realized by the fact that during photosynthesis the solar energy accumulates as chemical energy in the created organic substances of the plants

- Energy utilization can be achieved without further increasing the amount of atmospheric carbon dioxide

- It helps to promote the conservation of mineral resources

- The emissions of pollutants $\left(\mathrm{CO}_{2}, \mathrm{CO}, \mathrm{SO}_{2}, \mathrm{C}_{\mathrm{X}} \mathrm{H}_{\mathrm{X}}\right)$ are significantly lower compared to fossil fuels

- Due to the overproduction of food in some regions it is possible to utilize rationally the crop lands

- It has a positive impact on rural development and creating jobs

$\underline{\text { Categories of biomass materials }}$

Within these definitions, biomass for energy can include a wide range of materials. The realities of the economics mean that high value material for which there is an alternative market, such as good quality, large timber, are very unlikely to become available for energy applications. However, there are huge resources of residues, co-products and waste that exist which could potentially become available, in quantity, at relatively low cost, or even negative cost (where there is currently a requirement to pay for disposal).

There are five basic categories of material:

- Virgin wood, from forestry, arboricultural activities or from wood processing

- Energy crops: high yield crops grown specifically for energy applications

- Agricultural residues: residues from agriculture harvesting or processing

- Food waste, from food and drink manufacture, preparation and processing, and postconsumer waste

- Industrial waste and co-products from manufacturing and industrial processes.

On the basis of the source of biomass, biomass can be classified into three categories:

- Primary biomass: biomass produced by agriculture and forestry and includes energy crops and agricultural crops such as short rotation trees, grasses and aquatic plants.

- Secondary biomass: biomass such as straw, stover and crop residues that is generated as a result of harvesting and processing of primary biomass such as lumber, pulpwood, and grains. It also includes processing residues and by-product streams from food, feed, fibre and materials production.

- Tertiary biomass: post-consumer residue streams from urban activities such as fats, greases, oils, construction and demolition debris/wood, as well as animal manure and other by-products from concentrated animal feed operations. 


\section{$\underline{\text { Primary and secondary biomass energy sources }}$}

1. Raising crops for energy use

The number of plants which can be taken into account for energy production is almost limitless, as lignin cellulose all of them are suitable for environmentally friendly energy production by means of tying solar energy, in addition to the presence of closed $\mathrm{CO}_{2}$ cycle.

The most important criteria for the selection of energy sources are as follows:

- allow the implementation of various production techniques,

- technologies and technology solutions of a well-working industry shall be utilized,

- there shall be a solution for the application of intensive and extensive production and utilization technologies,

- they shall allow to choose between a wide variety of crop land conditions.

a. Herbaceous plants

They main characteristics are: a large number of crops per hectare, relatively small plant height, applicability of the developed technologies and technical solutions in agriculture. A great benefit of growing such crops and using such technologies is the following: there is no need for fundamental technical and technological changes in agriculture. However, due to the annual harvesting of biomass and the life cycle of plants, there is a large number of harvests which cannot be deferred.

The most important sources of biomass energy in the future could be:

- Rapeseed (Brassica napus)

- Hemp (Cannabis sativa L.)

- Triticale ( $\times$ Triticosecale)

- Bromegrass (Bromus inemis Leyss)

- Reed Canarygrass (Phalaris arundinacea L.)

- Silvergrass (Mischantus)

b. Woody energy crops

Woody plants, like herbaceous plants, are also lignocellulosic but they are perennials and the above-ground parts grow further each year. The solar energy tying and $\mathrm{CO}_{2}$ cycle is the as in the case of plant featured, but the fundamental difference is that woody energy crops do not need to harvest every year. Even if a planned harvest fall short for some reason, the plants continue to grow, so technological problems do not arise.

The most important ones are:

- Robinia (e.g. black locust)

- Willow (Salix sp.)

- Poplar, aspen, cottonwood (Populus)

2. Energy forestry

The energy forest is a special type of tree plantation, from which a large amount of wellburning biofuels can be obtained in the shortest time with the lowest costs. The energy forests should be planted in the agriculturally not utilized or abandoned areas. These plantations can 
be differed by the length of the cutting cycle: mini- (1-4 years), midi- (5-10 years), short(11-15 years), medium- (16-19 years), and long-term (20-25 years).

The types of trees which are suitable to be planted in energy forests due to their rapid growth, high dry matter yields and thanks to the ease of producibility and processability are: Robinieae, linden, maple, willow, alder and poplar.

This section shew how wide the range of plants for producing biomass-based energy is, but there are many factors which inhibit their production. The most important ones are the nonsmooth acceptance by the producers and the society. It is difficult to insert the processing method into the existing agrotechnology, small energy yield of biomass per hectare, and high investment demand for producing energy.

\section{$\underline{\text { Utilization possibilities: }}$}

Biomass as an energy resource can be utilized as follows:

1. Directly:

- Firing without preparation or after preparation

2. Indirectly

- After chemical transformation (liquefaction, gasification) as liquid fuel or combustible gas

- After fermenting into alcohol as fuel

- By esterification of vegetable oils as biodiesel

- After anaerobic fermentation as biogas

Pros and cons of biomass utilization

The primary advantages of biomass-based energy sources can be experienced in environmental protection, rural development, energy policy and waste management:

- Reduced economic dependence on imports

- Provide continuous energy production

- Decrease surplus agricultural products (food)

- Improve incomes generating ability of the rural population

- Improve state of the environment

- They are available almost everywhere, not locally restricted

- They can use agricultural waste

- Large investments are not required in a certain location

Inhibiting factors of energetic utilization of biomass

- Thick-featured and well-developed gas pipeline network

- Expensive equipment, long payback period

- Space requirement for material storage

- Expensive delivery

- Labour-intensive technology

- Limited investment sources and State's support

- Lack of knowledge 


\section{$\underline{\text { Calculation of available biomass }}$}

The studies and estimates on biomass resources (especially the studies that consider all types of biomass for relatively large geographical areas) generally have to face problems connected to the reliability of data relating to existing residues, wastes, potential biomass by energy crops and also connected to the definition of available resources, when limits (including technical and economical ones) are uncertain. To evaluate available biomass it is necessary to include into the model the different restrictions (environmental, social and economic) that can limit its availability. Once those available biomasses have been found, their uses could be only partially sustainable. The evaluation of 'Sustainability Biomass Supply' (SBS) is possible just evaluating and monitoring all key aspects of the bioenergy chain. A calculation of 'Available Biomass Supply' (ABS) from 'Potential Biomass Supply' (PBS) is showed following.

In general, the amount of materials can be estimated using the following formula that returns the available tonnes of Biomass per year, taking into consideration the respective biomass indexes above-mentioned. The aim is to estimate the amount of biomass (both like primary product and residues) that can be collected over a certain region.

where:

$$
\begin{aligned}
& \text { Biomass }_{i}=\text { Area or cattle dedicated }_{i} \times \text { Yield }_{i} \times \text { RtP }_{i} \times\left(1-\text { loss }_{i}\right) \\
& \times\left(1-\text { current }_{\text {use }}\right) \times\left(1-\text { ecol }_{i}\right) \times \text { econ }_{i}
\end{aligned}
$$

- Area or cattle dedicated $\left(\mathrm{ha} / \mathrm{n}^{\circ}\right.$ cattle): is the area or number of cattle involved $i$ in the studied region;

- $\quad$ Yield $_{i}(\mathrm{t} / \mathrm{ha})$ : is the yield of crop or manure by cattle $i$ in the studied region;

- $R t P_{i}$ : is the residue-to-product ratio for crop/or manure by cattle $i$;

- $\operatorname{Loss}_{i}(\%)$ : losses of residues due to technical issues $i$;

- Current use $(\%)$ : current use of residues i;

- $\operatorname{Ecol}_{i}(\%)$ : fraction of residues that should not be removed due to ecological issues $i$;

- $\operatorname{Econ}_{i}(\%)$ : fraction of residues that is economically convenient to use for energy conversion $i$.

\subsubsection{Principles of biomass energy utilization}

Different international organizations like the European Union, the World Energy Council, and others... suggest a number of principles of biomass energy utilization and also recommend different criteria for the sustainable use of biomass energy.

In this sense, the EU has defined a set of sustainability criteria to ensure that the use of biofuels (used in transport) and bioliquids (used for electricity and heating) is done in a way that guarantees real carbon savings and protects biodiversity. Only biofuels and bioliquids that comply with the criteria can receive government support or count towards national renewable energy targets. ${ }^{1}$

The main criteria in this respect:

- To be considered sustainable, biofuels must achieve greenhouse gas savings of at least $35 \%$ in comparison to fossil fuels. This savings requirement rises to $50 \%$ in 2017 . In 2018 , it rises again to $60 \%$ but only for new production plants. All life cycle emissions

\footnotetext{
${ }^{1}$ For the related legislation see https://ec.europa.eu/energy/en/topics/renewable-energy/biofuels/sustainabilitycriteria
}

"The European Commission support for the production of this publication does not constitute an endorsement of the contents which reflects the views only of the authors, and the Commission cannot be held responsible for any use which may be made of the information contained therein." 
are taken into account when calculating greenhouse gas savings. This includes emissions from cultivation, processing, and transport.

- Biofuels cannot be grown in areas converted from land used previously as high carbon stock such as wetlands or forests.

- Biofuels cannot be produced from raw materials obtained from land with high biodiversity such as primary forests or highly biodiverse grasslands.

According to the World Energy Council, the sustainability principles are the overarching goals that the individual producers should aim at. In terms of biomass energy, sustainability is regarded as a threefold paradigm, entailing social, economic and environmental dimensions. A sustainability standard should account for all three fields, while adding specifications on the greenhouse gas emissions savings, life cycle assessment, chain-of-custody, verification and auditing. Principles encompass the general aspirations that are expressed using broad, openended wording. The principles form the actual sustainability framework, by setting the tone of the degree of ambitions. The criteria specifies the concrete aspects of each principle and they should detail all necessary steps for compliance with the principle.

\section{Social sustainability}

Social sustainability reflects how the production of biomass for energy, including transport applications, impacts local development. In particular, social sustainability aims to ensure that the human, land rights and land use rights are respected. It also tackles issues like labour standards, safety standards. Any sustainability standard and especially one that touches upon agriculture and local development, dedicates a main important part to social aspects. A standard that aims to be universally applicable is bound to include provisions on the social side.

Social principles and criteria:

- Labour rights of the local people should be respected

- Land and land use rights of the local population should be respected

- The land use rights are demonstrable and there is no conflict of claims with the local population

○ The use of agricultural land for the cultivation of biomass for energy applications will not distort the land and customary rights of the local population

- The relation with the local community and the responsibility-sharing between parties should ensure local development

$\circ$ The local community should be consulted in matters related to the land management

- The negative impacts of land management on the local community should be minimized and the positive impacts maximized

\section{Economic sustainability}

The economic sustainability is a prerequisite for sustainable production of biomass for energy applications including transportation purposes. Local development issues are not only relevant from a social sustainability perspective, but also from the economic sustainability angle. In addition, economic viability of individual operators has to be ensured.

Economic principles and criteria: 
- New projects (e.g. plant building, crop cultivation, etc....) should ensure economic profitability and contribute to the local development of the region

- An equitable profit sharing should be carried out between the owners, the employees and the local community

○ The local economic conditions should improve in time

\section{Environmental sustainability}

Sustainability standardization of biomass (e.g. for biofuels) cannot overlook the environmental aspects. Environmental sustainability of a biomass-related project is essential for the conception of sustainability standards and finally plays a key role in the phase of compliance with principles and criteria laid down in such standards.

Environmental sustainability addresses issues related to, but not restricted, biodiversity, land preservation, water and soil preservation. In a first step it will set clear definitions of concepts, thresholds, etc. since the whole aim of replacing conventional energy with renewable sources is gravitating around the greenhouse gas (GHG) emission reductions that the latter bring. Accordingly, a standard for sustainably produced biomass for energy and/or transport must refer to the GHG emission reductions.

Environmental principles and criteria:

- The conservation of the biodiversity, ecosystems and the protected areas must be ensured by the production of biomass for energy or other applications

- An ex-ante assessment of the biodiversity, ecosystem and protected areas should be conducted in case there is no other assessment for reference

- The endangered species and areas should be identified and their protection should be evaluated

- The use of best practices in the production of biomass for energy and other applications should be guaranteed so as to ensure the soil preservation and the minimization of negative impacts

- The employed practices ensure soil preservation and fertility, while accounting for obtaining balanced yields

- Wastes and by-products use/disposal is conducted to preserve soil health and fertility

- The use of best practices in the production of biomass for energy and other applications should be guaranteed so as to ensure the water preservation and the minimization of negative impacts like contamination or induced scarcity

o The employed practices ensure conformity with water management rules, usage rights and water availability factor

- The employed practices ensure water availability both on the surface and in the ground.

- The production of biomass for energy applications should ensure GHG emissions savings when compared with the conventional energy sources

$\circ$ The GHG emissions savings from the production of biofuels accounting for all the life cycle emissions should ensure the compliance with the legislation in force on the specific territory

- The GHG emissions savings from the production of biomass for energy and other applications should improve in time 


\section{Renewable energy for local development course}

- The GHG emissions accounting for the production of biomass for energy and other applications should be done in a life cycle approach, having the system boundaries in accordance with the legislation in force on the territory, if such legislation exists

- When selecting biomass sources for energy use, people shall strive for a significant contribution to climate protection, considering all essential process steps in the value chain.

\subsubsection{Biomass in Europe}

Large amounts of solid biomass are currently produced, traded, and used for energy purposes in the European Union, but this trade is largely uncharted. Also, increasing volumes of unrefined and refined biomass are being imported from outside the EU to several European countries. While the traded volumes are most likely in most cases relatively small compared to local production and consumption of solid biomass, biomass trade has shown a strong growth in recent years, and there are good reasons to believe that this will continue in the years to come. Especially countries with little domestic biomass resources and high targets for renewable electricity, renewable heat and (eventually second generation) liquid biofuels may increasingly depend on imported solid biomass. On the other hand, countries with ample solid biomass resources are increasingly discovering the international markets for solid biomass, and especially wood pellet plants are frequently built with the main (or sole) purpose of export.

Figure 1 presents the reported availability of biomass resources in EUBIONET III $^{2}$ partner and subcontractor countries. The total annual figure for reported biomass resources in $24 \mathrm{EU}$ countries and Norway is around 6,577 PJ (157 Mtoe). According to EUBIONET III study, $50 \%$ of the annual biomass potential is currently used in the EU-24 and Norway.

The greatest potential (46\%) to increase the use of biomass in energy production seems to lie in forest residues and herbaceous \& fruit biomass. The utilisation of forest residues is often connected with round wood harvesting especially in Nordic countries, so the use of round wood by the forest industry impacts also the exploitation of the forest residue potential. Industrial by-products and residues (bark, sawdust, cutter chips, grinding dust, etc.) are quite well exploited in energy production and pellet or briquette production. The availability and cost of forest biomass varies considerably between countries and within countries. The most common biomass fuel is forest wood (wood chips, firewood and hog fuel). In general, the availability of forest resources, the demand for forest fuels, and machine and labour costs are the defining factors behind prices. Usually, both the optimal harvesting technology and the availability of forest fuel must be studied on a local level for reliable results.

\footnotetext{
${ }^{2}$ The EUBIONET III project aimed to increase the use of biomass-based fuel in the EU by finding ways to overcome market barriers. The results of the EUBIONET III project contribute to a sustainable, transparent international biomass fuel trade, secure the most cost efficient and value-adding use of biomass for energy and industry, boost the investments on best practice technologies and new services on biomass heat sector and enhance sustainable and fair international trade of biomass fuels. EUBIONET III was supported by the European Commission under the Intelligent Energy - Europe Programme.
}

"The European Commission support for the production of this publication does not constitute an endorsement of the contents which reflects the views only of the authors, and the Commission cannot be held responsible for any use which may be made of the information contained therein." 


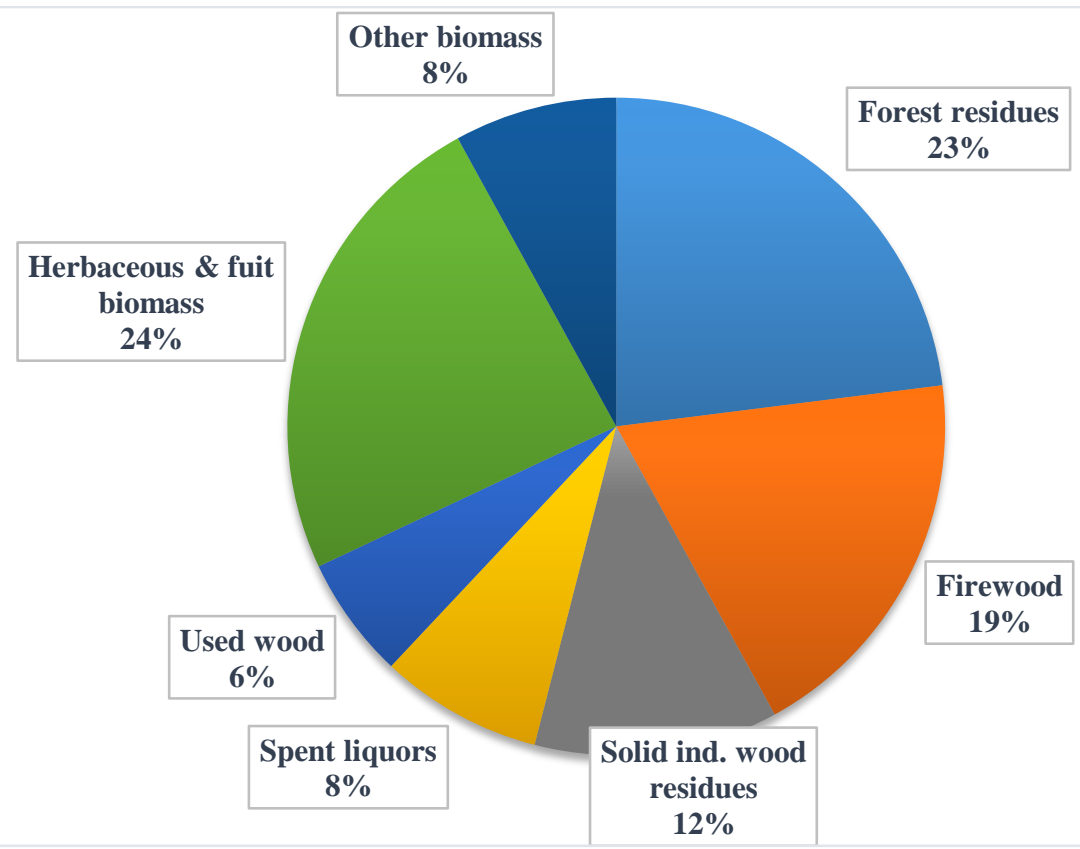

Figure 1. Biomass resources by type in the EU-24 and Norway. (Source: EUBIONET III, 2011)

According to reported data, the following countries have the lowest total annual biomass resources (< 100 PJ): Bulgaria (42 PJ), Belgium (50 PJ), Denmark (34 PJ), Estonia, (48 PJ), Lithuania (47 PJ), Slovenia (53 PJ), Slovak Republic (72 PJ), the Netherlands (77 PJ) and Greece (74 PJ). In turn, Germany (1,080 PJ), Sweden (841 PJ), Spain (588 PJ), France (574 PJ), Italy (484 PJ) and Finland (428 PJ), are the EU countries endowed with the richest biomass resources, Figure 2. Sweden, Finland, Germany and France have the largest volumes of forest residues.

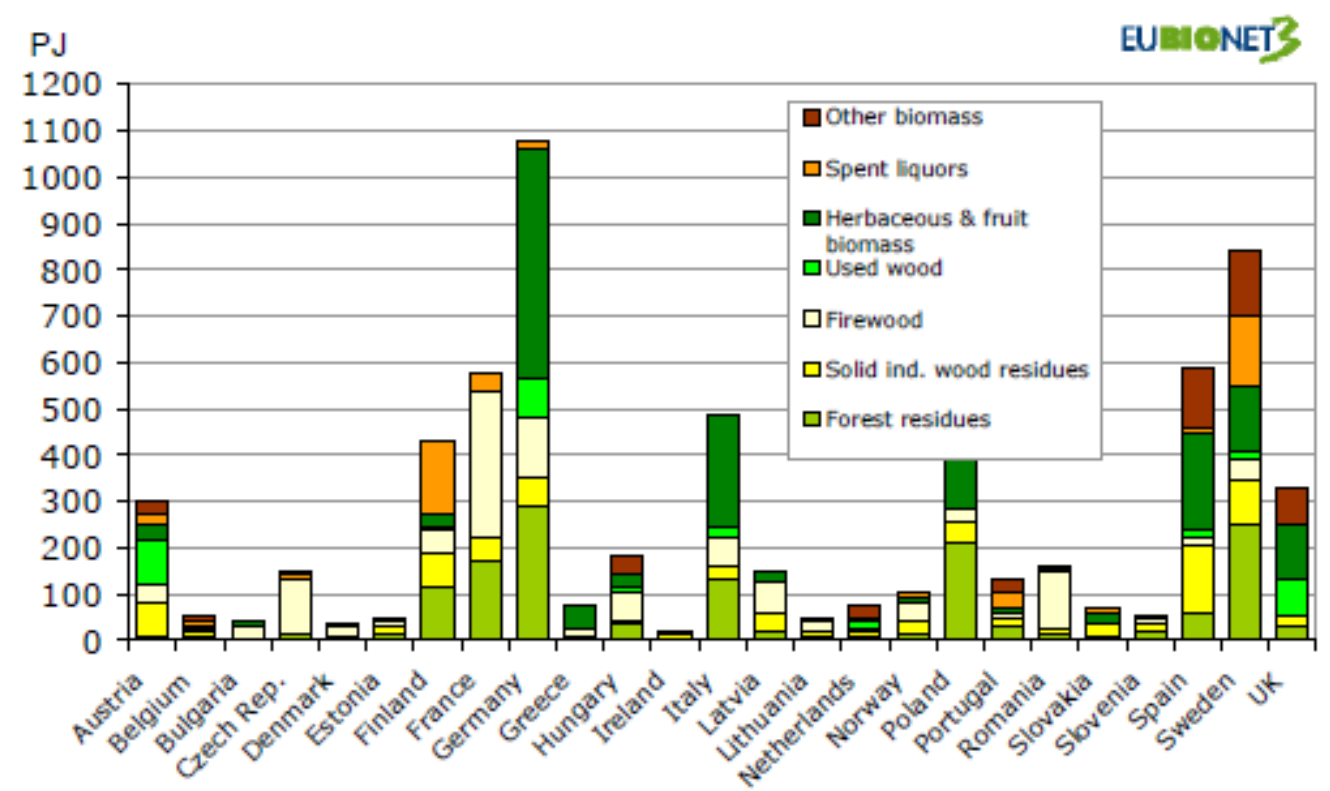

Figure 2. Biomass resources by different types in the EU-24 and Norway. (Source: EUBIONET III, 2011) 


\subsubsection{Conditions for efficient exploitation}

While planning biomass energy utilization, it is essential to define the reasons and the goals to use it since the establishment of the most appropriate production systems depends on these factors. There is a wide variety of reasons for using biomass-based energy in a local community, in a village, in a town or within a national economy:

- Reduce the emissions of GHGs,

- Reduce import dependency by increasing self-sufficiency capabilities,

- Increase the profitability of agricultural production and to diversify it,

- Increase export revenues,

- Import raw materials,

- Meet the investors' needs, if the power plant is regarded as it is financed like a company's investment.

Certainly, the reasons above have different emphasis while creating a strategy, but it is not possible to fulfil them jointly and simultaneously at a $100 \%$. However, in terms of sustainability it is achievable to select the principles that determine the ranking of these objectives.

According to these principles, the use of biomass for energy production is reasonable primarily for environmental purposes, to reduce GHGs. So it is not practical to develop and operate energy producing systems, which emission more GHGs than the replaced systems. An important goal of bioenergy development is to increase energy independence, which may also cut down import costs and may improve the trade balance. In addition, developments aiming to diversify the economy of the rural population, to achieve energy independence and to increase incomes while making them more predictable, can also improve the population retaining ability of the rural territories.

\section{References}

Alakangas, E. et. al. (2011). Solutions for biomass fuel market barriers and raw material availability: Summary of the EUBIONET III project results. EUBIONET III. Retrieved 2/02/2016, from http://www.eubionet.net/GetItem.asp?item=digistorefile;325123;1770\&params=open;gallery

Altawell, N. (2014). The Selection Process of Biomass Materials for the Production of BioFuels and Co-firing. Wiley.

Austrian Energy Agency (2012). Basic Data Bioenergy Austria 2012. 4Biomass. Retrieved 2/02/2016, from http://www.4biomass.eu/document/file/basic-data-bioenergy-austria2012.pdf

Bartholy, J. et. al. (2013). Megújuló energiaforrások. Eötvös Loránd Tudományegyetem.

Baskar, C., Baskar, S., \& Dhillon, R. S. (eds.) (2012). Biomass Conversion: The Interface of Biotechnology, Chemistry and Materials Science. Springer.

Bíró, Borbála (2010). Biomassza hasznositás. Edutus Főiskola.

Bridgwater, A. V., \& Grassi, G. (eds.) (1991). Biomass Pyrolysis Liquids Upgrading and Utilization. Springer. 
BTG biomass technology group BV (2009). Guideline for Safe and Eco-friendly Biomass Gasification. BTG biomass technology group $B V$. Retrieved 2/02/2016, from http://www.gasification-guide.eu/gsg_uploads/documenten/D10_Final-Guideline.pdf

Caputo, A. C.; Palumbo, M.; Plagagge, M., \& Scacchia, F. (2005). Economics of biomass energy utilization in combustion and gasification plants: effects of logistic variables. Biomass and Bioenergy, 28, 35-51.

Chang, J. (ed.) (2010). Biomass to Renewable Energy Processes. CRC Press.

Chen, H. (2013). Gas Explosion Technology and Biomass Refinery. Springer.

Dahlquist, E. (ed.) (2012). Biomass as Energy Source: Resources, Systems and Applications. CRC Press.

Dahlquist, E. (ed.) (2013). Technologies for Converting Biomass to Useful Energy: Combustion, gasification, pyrolysis, torrefaction and fermentation. CRC Press.

Dzikuć, M., \& Łasiński, K. (2014). Technical and Economic Aspects of Biomass Co-Firing in Coal-Fired Boilers. International Journal of Applied Mechanics and Engineering, Volume 19, Issue 4, 849-855.

European Climate Foundation (2010). Biomass for heat and power - opportunity and economics. European Climate Foundation. Retrieved 2/02/2016, from http://www.europeanclimate.org/documents/Biomass_report___Final.pdf

European Commission (2014). Commission Staff Working Document: State of play on the sustainability of solid and gaseous biomass used for electricity, heating and cooling in the EU. European Commission. Retrieved 2/02/2016, from http://www.energimyndigheten.se/contentassets/c8d0f7c162814b7c9e0764cb2e8b7445/2014_ biomass_state_of_play_pdf

Gergely, S. (2012). Biomasszatüzelés. Károly Róbert Főiskola.

German Solar Energy Society (DGS) \& Ecofys (2004). Planning and Installing Bioenergy Systems: A Guide for Installers, Architects and Engineers. Routledge.

Gikonyo, B. (ed.) (2015). Fuel Production from Non-Food Biomass: Corn Stover. Apple Academic Press.

Grassi, G.; Collina, A., \& Zibetta, H. (eds.) (1990). Biomass for Energy, Industry and Environment: 6th E.C. Conference. CRC Press.

Gyulai, I. (2009). A biomassza-dilemma. Magyar Természetvédők Szövetsége.

Hakeem, K. R.; Mohammad, J., \& Alothman, O. Y. (eds.) (2015). Agricultural Biomass Based Potential Materials. Springer.

International Energy Agency (2007). Good Practice Guidelines: Bioenergy Project Development Biomass Supply. OECD/IEA. Retrieved 2/02/2016, from https://www.iea.org/publications/freepublications/publication/biomass.pdf

IRENA (2012). Biomass for Power Generation. IRENA Working Paper: Renewable Energy Technologies: Cost Analysis Series. Retrieved 2/02/2016, from 
https://www.irena.org/DocumentDownloads/Publications/RE_Technologies_Cost_AnalysisBIOMASS.pdf

Jansen, R. A. (2012). Second Generation Biofuels and Biomass: Essential Guide for Investors, Scientists and Decision Makers. Wiley.

Juhász, Á. et. al. (2009). Megújuló energiák. Sprinter Kiadói Csoport.

Matovic, M. D. (ed.) (2013). Biomass Now-Cultivation and Utilization. InTech.

Matovic, M. D. (ed.) (2013). Biomass Now - Sustainable Growth and Use. InTech.

Milbrandt, A. (2005). A Geographic Perspective on the Current Biomass Resource Availability in the United States. National Renewable Energy Laboratory. Retrieved 2/02/2016, from http://www.nrel.gov/docs/fy06osti/39181.pdf

OECD (2004). Biomass and Agriculture: Sustainability, Markets and Policies. OECD Publishing.

Overend, R. P.; Milne, T. A., \& Mudge, L. K. (eds.) (1985). Fundamentals of Thermochemical Biomass Conversion. Elsevier.

Pappné Vancsó, J. (2010). A biomassza, mint energiaforrás hasznositási lehetöségei, különös tekintettel Magyarországra. PhD Thesis.

Rátonyi, T. (2013). Biomassza anyagismeret. Debreceni Egyetem.

Reed, T. B., \& Das, A. (1988). Handbook of Biomass Downdraft Gasifier Engine Systems. The Biomass Energy Foundation Press.

Réczey, G. (2007). A biomassza energetikai hasznositásának lehetősége és a vidékfejlesztésre gyakorolt hatása az Európai Unió támogatási rendszerének tükrében. $\mathrm{PhD}$ Thesis.

Riva, G. et. al. (2012). Handbook on Renewable Energy Sources. ENER SUPPLY. Retrieved 2/02/2016, from http://www.ener-supply.eu/downloads/ENER_handbook_en.pdf

Rosillo-Calle, F.; de Groot, P.; Hemstock, S. L., \& Woods, J. (eds.) (2007). The Biomass Assessment Handbook: Bioenergy for a Sustainable Environment. Earthscan.

Sembery, P., \& Tóth, L.(eds.) (2004). Hagyományos és megújuló energiák. Szaktudás Kiadó Ház Zrt.

Serrano-Ruiz (ed.) (2015). Advanced Biofuels: Using Catalytic Routes for the Conversion of Biomass Platform Molecules. Apple Academic Press.

Tóth, P.; Bulla, M., \& Nagy, G. (2008): Energia és Környezet, UNIVERSITAS- Györ Nonprofit Kft, az eredeti kiadvány 1999. átdolgozott 2008. évi változata alapján.

van Loo, S., \& Koppejan, J. (eds.) (2008). The Handbook of Biomass Combustion and Cofiring. Earthscan.

Vertès, A. A.; Qureshi, N.; Blaschek, H. P., \& Yukawa, H. (eds.) (2010). Biomass to Biofuels: Strategies for Global Industries. Wiley. 


\section{MODULE 3: BIOMASS}

CHAPTER 1. Technical aspects.

Subchapter 1.2.: Technical alternatives and installation types for 'biomass' installations applicable for rural development.

Dr. Zsolt Radics

Geolin Co., Hungary

Summary: The chapter gives an introduction to the main concepts of biomass. The students get familiar with the categories of biomass materials and the principles of biomass utilization. The chapter also gives a detailed analysis about the utilization of biomass, the technical alternatives and installation types of biomass power plant. By acquiring the material of the subchapter, the students get familiar with the concepts concerned with biomass, the principles of biomass energy utilization, the status of biomass in Europe and the conditions for efficient exploitation.

\section{Technical alternatives and installation types for 'biomass' installations applicable for rural development: Introduction.}

The majority of biomass that is available for bioenergy projects is solid unprocessed plant material with moisture content that is generally around 50\%. There is a wide range of available biomass resources associated with human activity, particularly, residues and wastes from agricultural, industrial, municipal, forest and other economic activities. All these resources can be processed taking into account different technologies: direct combustion (for power and/or heat, CHP systems), anaerobic digestion (CHP, for methane rich gas), fermentation (of sugars for alcohols, bioethanol), oil extraction (for biodiesel), pyrolysis (for bio-char, gas and oils), and gasification (for carbon monoxide $\mathrm{CO}$ and hydrogen $\mathrm{H} 2$ rich syngas) (see Figure 1).

There are a number of technological options available to make use of a wide variety of biomass types as a renewable energy source. Conversion technologies may release the energy directly, in the form of heat or electricity, or may convert it to another form, such as liquid biofuel or combustible biogas. While for some classes of biomass resource there may be a number of usage options, for others there may be only one appropriate technology.

Each technology process can also be followed by an array of secondary treatments (i.e.: stabilisation, dewatering, upgrading, refining) depending on specific final products. The versatility of biomass processing technologies to produce energy and materials in electricity, heat or CHP system, gas, liquids and solid forms, are shown in Table 1.

Table 1. Overview of biomass Technologies. (Source: Riva, G. et. al., 2012)

\begin{tabular}{|l|c|c|c|c|c|}
\hline \multirow{2}{*}{ Technologies } & \multicolumn{5}{c|}{ Energy and Biofuel Outputs } \\
\cline { 2 - 6 } & Heat & Electricity & Gas & Liquid & Solids \\
\hline Direct Combustion & $\mathrm{X}$ & $\mathrm{X}$ & & & \\
\hline Anaerobic Digestion & $\mathrm{X}$ & $\mathrm{X}$ & $\mathrm{X}$ & & \\
\hline Fermentation & & & & $\mathrm{X}$ & \\
\hline
\end{tabular}




\begin{tabular}{|l|c|c|c|c|c|}
\hline Oil Extraction & & & & $\mathrm{X}$ & \\
\hline Pyrolysis & $\mathrm{X}$ & $\mathrm{X}$ & $\mathrm{X}$ & $\mathrm{X}$ & $\mathrm{X}$ \\
\hline Gasification & $\mathrm{X}$ & $\mathrm{X}$ & $\mathrm{X}$ & $\mathrm{X}$ & \\
\hline
\end{tabular}

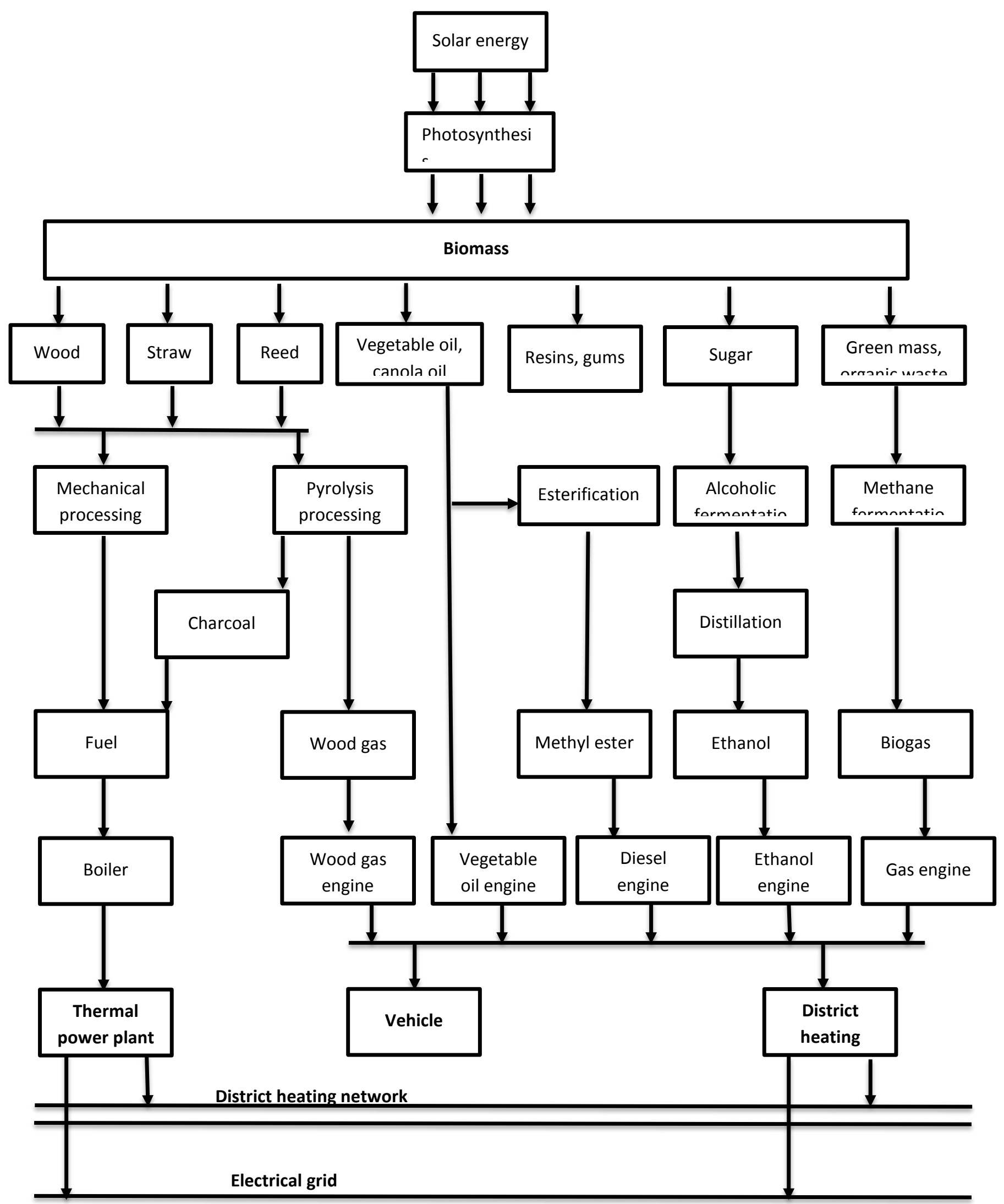

Figure 1. Conversion process of biomass to energy. (Source: Tóth - Bulla - Nagy, 2008)

"The European Commission support for the production of this publication does not constitute an endorsement of the contents which reflects the views only of the authors, and the Commission cannot be held responsible for any use which may be made of the information contained therein." 


\section{Renewable energy for local development course}

A synthesis of the key factors for biomass processing technologies is presented in Table 2 . Thermal technologies are the least sensitive to the qualities of the feedstock and can effectively process lignocellulosic materials. These technologies are the most sizeable and do not require on grown purpose biomass. Technologies different from direct combustion are significantly limited in scale for their dependence on specific and finite feedstocks. Technologies that provide high volume and value opportunities are at present the less developed and are candidates for future innovation.

Table 2. Comparison between Technologies for the energy conversion of Biomass. (Source: Riva, G. et. al., 2012)

\begin{tabular}{|l|c|c|c|c|c|c|}
\hline $\begin{array}{l}\text { Biomass } \\
\text { processing } \\
\text { technology }\end{array}$ & $\begin{array}{c}\text { Possible } \\
\text { Scale }^{\mathbf{1}}\end{array}$ & $\begin{array}{c}\text { Feedstock } \\
\text { Flexibility }\end{array}$ & $\begin{array}{c}\text { Conversion } \\
\text { efficiency }^{2}\end{array}$ & $\begin{array}{c}\text { Output } \\
\text { Flexibility }^{\text {Market }}\end{array}$ & $\begin{array}{c}\text { Malue of } \\
\text { Product }\end{array}$ & $\begin{array}{c}\text { Development } \\
\text { Status }\end{array}$ \\
\hline $\begin{array}{l}\text { Direct } \\
\text { Combustion }\end{array}$ & Large & High & Low & Low & Low & Established \\
\hline $\begin{array}{l}\text { Anaerobic } \\
\text { Digestion }\end{array}$ & Small & Medium & Medium & Low & Medium & Established \\
\hline Fermentation & Medium & Medium & Medium & Low & High & Established \\
\hline $\begin{array}{l}\text { Oil } \\
\text { Extraction/ } \\
\text { Esterification }\end{array}$ & Small & Low & High & Low & High & Established \\
\hline Pyrolysis & Large & High & Medium & High & Medium & $\begin{array}{c}\text { Early } \\
\text { Commercial }\end{array}$ \\
\hline Gasification & Large & Medium & Medium & Medium & Medium & $\begin{array}{c}\text { Early } \\
\text { Commercial }\end{array}$ \\
\hline
\end{tabular}

${ }^{1}$ Scale of possible industry is dependent on the scale of the available biomass resource. Those technologies able to use lignocellulosic biomass are at an advantage.

${ }^{2}$ Energy efficiency measures the amount of energy in the feedstock retained in the products.

${ }^{3}$ De-polymerisation of cellulose to sugars will allow access to a larger biomass pool; however, this technology is not commercially established.

${ }^{4}$ This may be higher if technologies that generate sugar feedstocks from cellulose become mature.

${ }^{5}$ The direct products of gasification are low, but this is the basis to a vast array of fuel and chemical products via synthesis reactions.

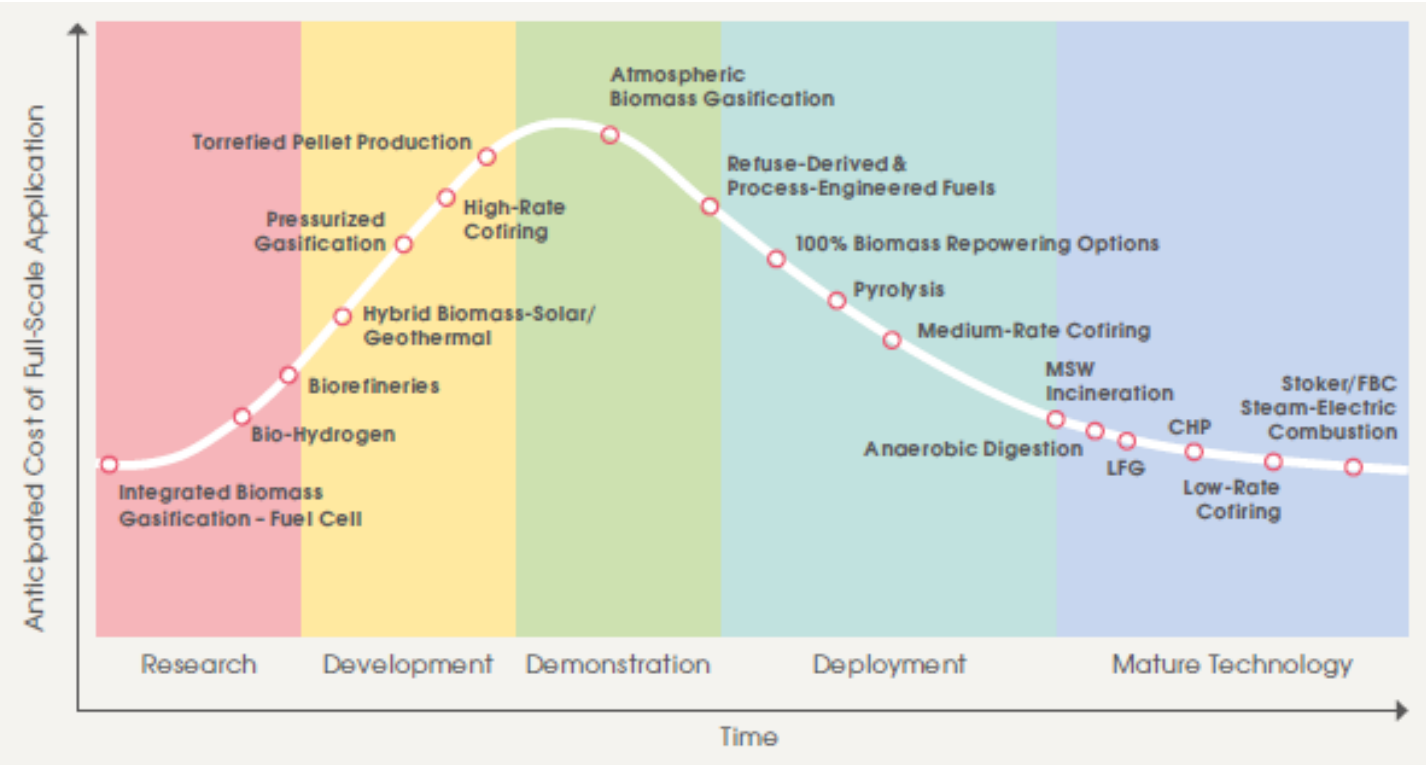




\section{Renewable energy for local development course}

Figure 2. Biomass power generation maturity status. (Source: IRENA 2012 based on EPRI 2011)

\section{$\underline{\text { Thermal conversion }}$}

These are processes in which heat is the dominant mechanism to convert the biomass into another chemical form. The basic alternatives are separated principally by the extent to which the chemical reactions involved are allowed to proceed:

- Combustion

- Gasification

- Pyrolysis

- Hydrothermal upgrading (HTU)

- Hydroprocessing

\section{Combustion}

Combustion is the process with which everyone is familiar by which flammable materials are allowed to burn in the presence of air or oxygen with the release of heat. So, the basic process is oxidation.

Combustion is the simplest method by which biomass can be used for energy, and has been used for millennia to provide heat. This heat can itself be used in a number of ways:

- Space heating

- Water (or other fluid) heating for central or district heating

- Steam raising for electricity generation or motive force.

When the flammable fuel material is a form of biomass, the oxidation is mainly performed over the carbon $(\mathrm{C})$ and hydrogen $(\mathrm{H})$ in the cellulose, hemicellulose, lignin, and other molecules present to form carbon dioxide $\left(\mathrm{CO}_{2}\right)$ and water $\left(\mathrm{H}_{2} \mathrm{O}\right)$.

\section{Gasification}

Gasification is a partial oxidation process whereby a carbon source such as coal, natural gas or biomass, is broken down into carbon monoxide $(\mathrm{CO})$ and hydrogen $\left(\mathrm{H}_{2}\right)$, plus carbon dioxide $\left(\mathrm{CO}_{2}\right)$, and possibly hydrocarbon molecules such as methane $\left(\mathrm{CH}_{4}\right)$.

This mix of gases is known as 'producer gas' or product gas (or wood gas or coal gas, depending on the feedstock), and the precise characteristics of the gas will depend on the gasification parameters, such as temperature, and also the oxidizer used. The oxidizer may be air, in which case the producer gas will also contain nitrogen $\left(\mathrm{N}_{2}\right)$, or steam, or even oxygen.

Gasification technology can be used for:

- Heating water in central heating, district heating or process heating applications

- Steam for electricity generation or motive force

- As part of systems producing electricity or motive force 
- Transport using an internal combustion engine.

Low temperature gasification: If the gasification takes place at a relatively low temperature, such as $700^{\circ} \mathrm{C}$ to $1000^{\circ} \mathrm{C}$, the product gas will have a relatively high level of hydrocarbons compared to high temperature gasification (see below). As a result it may be used directly, to be burned for heat or electricity generation, via a steam turbine or, with suitable gas clean up, to run an internal combustion engine for electricity generation.

High temperature gasification: Higher temperature gasification $\left(1200^{\circ} \mathrm{C}\right.$ to $\left.1600^{\circ} \mathrm{C}\right)$ leads to few hydrocarbons in the product gas, and a higher proportion of $\mathrm{CO}$ and $\mathrm{H}_{2}$. This is known as synthesis gas (syngas or biosyngas) as it can be used to synthesize longer chain hydrocarbons using techniques such as Fischer-Tropsch (FT) synthesis. If the ratio of $\mathrm{H}_{2}$ to $\mathrm{CO}$ is correct (2:1), FT synthesis can be used to convert syngas into high quality synthetic diesel biofuel which is completely compatible with conventional fossil diesel and diesel engines.

3. Pyrolysis

Pyrolysis is the precursor to gasification, and takes place as part of both gasification and combustion. It consists of thermal decomposition in the absence of oxygen. It is essentially based on a long established process, being the basis of charcoal burning. The products of pyrolysis include gas, liquid and a sold char, with the proportions of each depending upon the parameters of the process.

Applications for pyrolysis include:

- Biomass energy densification for transport or storage

- Co-firing for heat or power

- Feedstock for gasification.

Lower temperatures (around $400^{\circ} \mathrm{C}$ ) tend to produce more solid char (slow pyrolysis), whereas somewhat higher temperatures (around $500^{\circ} \mathrm{C}$ ) produce a much higher proportion of liquid (bio-oil), provided the vapour residence time is kept down to around $1 \mathrm{~s}$ or less. After this, secondary reactions take place and increase the gas yield.

The bio-oil produced by fast (higher temperature) pyrolysis is described as a dark brown, mobile liquid with a heating value about half that of conventional fuel oil. It can be:

- Burned directly

- Co-fired

- Upgraded to other fuels

- Gasified

It can therefore be used as an energy vector, effectively increasing the energy density of biomass for transportation and storage.

\section{Hydrothermal upgrading (HTU)}

There are a range of less widely practised, biomass conversion technologies that find relevance under particular circumstances, or that may be still experimental or use a 
proprietary technology. They typically use heat and catalysts to convert biomass into another, more convenient form, either of higher energy density or more easily exploited. One of these processes is hydrothermal upgrading (HTU).

HTU is a liquefaction process that has been developed specifically to convert high moisture content biomass into a product with higher energy density.

\section{Hydroprocessing}

Hydrogenation of vegetable oils to remove all the unsaturated (double) bonds and the glycerol ester component of the triglyceride can be used to yield a range of simple paraffins.

Careful control of reaction conditions and subsequent refining can give a high quality diesel biofuel, superior to fossil diesel.

\section{Chemical conversion}

A range of chemical processes may be used to convert biomass into other forms, such as to produce a fuel that is more conveniently used, transported or stored, or to exploit some property of the process itself.

\section{Biochemical conversion}

As biomass is a natural material, many highly efficient biochemical processes have been developed in nature to break down the molecules of which biomass is composed, and many of these biochemical conversion processes can be harnessed.

Biochemical conversion makes use of the enzymes of bacteria and other microorganisms to break down biomass. In most cases micro-organisms are used to perform the conversion process:

- Anaerobic digestion

- Fermentation

- Composting

a. Anaerobic digestion

Anaerobic digestion (AD) is the process whereby bacteria break down organic material in the absence of air, yielding a biogas containing methane.

The products of this process are:

- Biogas (principally methane $\left(\mathrm{CH}_{4}\right)$ and carbon dioxide $\left(\mathrm{CO}_{2}\right)$ )

- A solid residue (fibre or digestate) that is similar, but not identical, to compost

- A liquid liquor that can be used as a fertilizer.

$\mathrm{NB}$, the term whole digestate can be used to describe the unseparated fibre and liquor. $\mathrm{AD}$ has been used to process sewage sludge since the 19th century. It is also the natural process that can break down organic material in pools and marshes to produce marsh gas and in landfills to produce landfill gas. AD is typically performed on biological material in an aqueous slurry. However there are an increasing number of 'dry' digesters. 
The methane can be burned for heat or electricity generation.

There are two basic AD processes, which take place over different temperature ranges. Mesophilic digestion takes place between $20^{\circ} \mathrm{C}$ and $40^{\circ} \mathrm{C}$ and can take a month or two to complete. Thermophilic digestion takes place from $50-65^{\circ} \mathrm{C}$ and is faster, but the bacteria are more sensitive.

b. Fermentation

Fermentation is the process used in brewing and wine making for the conversion of sugars to alcohol (ethanol $-\mathrm{CH}_{3} \mathrm{CH}_{2} \mathrm{OH}$ ). The same process, followed by distillation, can be used to obtain pure ethanol (bioethanol) for use as a transport biofuel.

Conventional fermentation processes for the production of bioethanol make use of the starch and sugar components of typically cereal or sugar (beet or cane) crops. Second generation bioethanol precedes this with acid and/or enzymatic hydrolysis of hemicellulose and cellulose into fermentable saccharides to make use of a much larger proportion of available biomass.

(Bio)ethanol can be readily added to conventional petrol in concentrations up to $10 \%$, but most European manufacturers' vehicle warranties only cover up to a 5\% bioethanol versus $95 \%$ petrol blend. Higher concentrations are also possible, however modifications are required in vehicles to use them. Flex fuel vehicles (FFVs) can run on either high bioethanol blends or $100 \%$ fossil fuels and many of the major vehicle manufacturers are developing them. There are also fuel handling issues associated with higher ethanol concentrations concerning its vapour pressure and affinity for water. Biobutanol, derived from bioethanol, has been proposed as an alternative that does not suffer from the above fuel handling issues.

c. Composting

Similarly to anaerobic digestion, though making use of different bacteria, composting is the aerobic decomposition of organic matter by microorganisms. It is however typically performed on relatively dry material rather than a slurry.

Instead of, or in addition to, collecting the flammable biogas emitted, the exothermic nature of the composting process can be exploited and the heat produced used, usually using a heat pump.

\section{Transesterification}

This chemical conversion process can be used to convert straight and waste vegetable oils into biodiesel.

Vegetable oils and animal fats are triglycerides: esters of glycerol with three fatty acid chains. Although some unmodified vegetable oils have been used as fuel in internal combustion engines, in general the viscosity is significantly higher than that of conventional diesel and a number of modifications are required to a vehicle's fuel system (including heaters, additional filters and modified injectors) to use them. Even then, the lack of a transport fuel specification for straight vegetable oil (SVO) and 
concerns about long term engine reliability using SVO as a fuel, make this inadvisable for the present.

Instead, SVO and filtered waste vegetable oil (WVO) can be reacted with methanol (or ethanol) to change the triglyceride esters into methanol (or ethanol) monoesters, each with single fatty acid chains making fatty acid methyl ester (FAME), commonly known as biodiesel, although not all oils and fats are suitable for this process.

The biodiesel produced can be used on its own or mixed with petroleum based diesel fuel as a 5\% biodiesel / 95\% fossil diesel blend and used by unmodified, conventional diesel engines. The European standard for FAME biodiesel is EN14214.

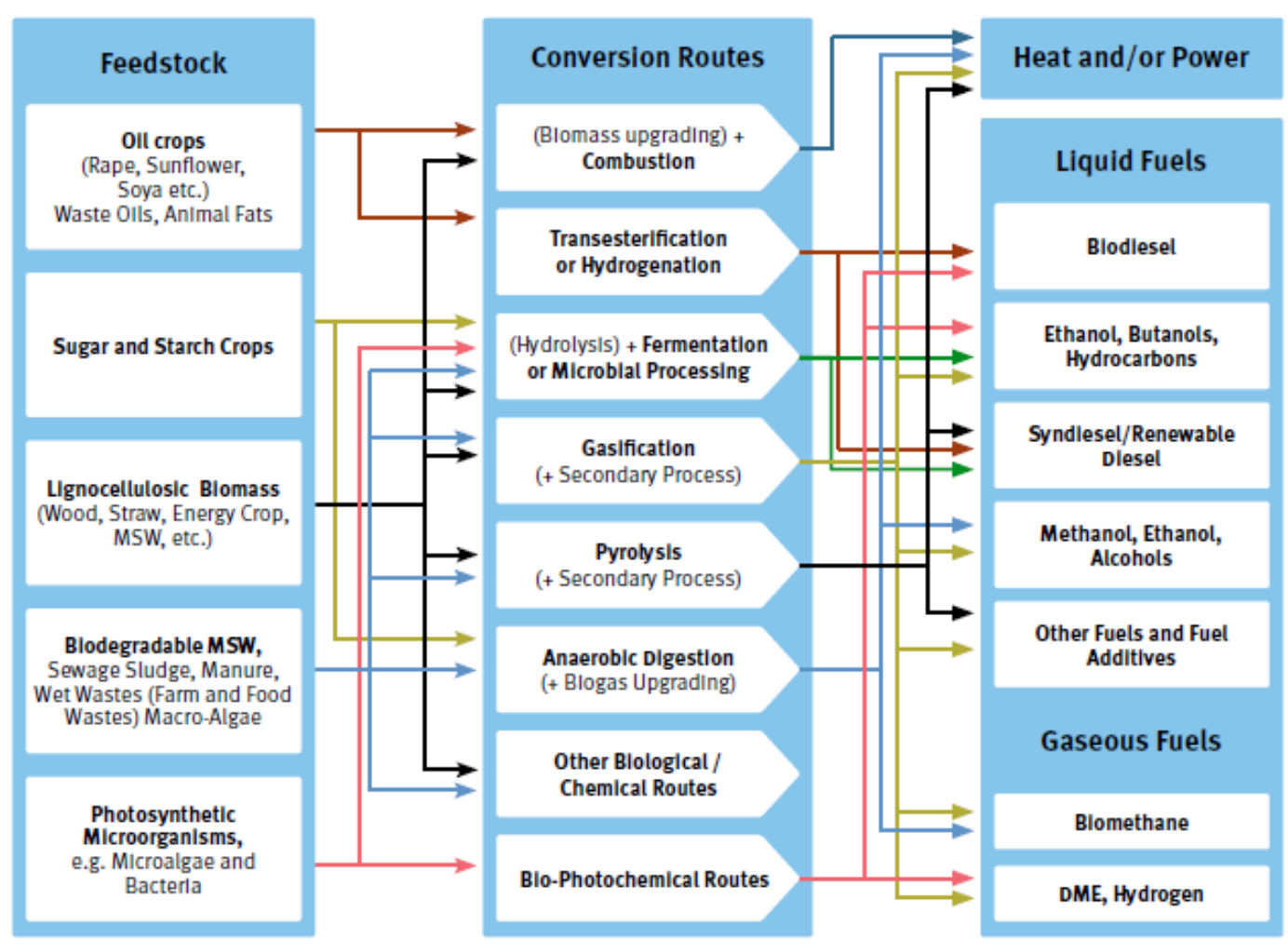

Figure 3. Schematic view of the variety of commercial and developing bioenergy routes from biomass feedstocks through thermochemical, chemical, biochemical and biological conversion routes to heat, power, CHP and liquid or gaseous fuels. (Source: UNIDO, 2014)

\subsubsection{Characteristics of biomass combustion}

The easiest way to produce energy from biomass is combustion. The heat obtained from the combustion is utilized by heating supplies (e.g. biomass heating plants in villages). The firing characteristics of biomass fuels are usually different, meanwhile other features are nearly the same. The calorific value of by-products depends on the material, the influencing environmental factors (storage conditions, humidity, etc.), but it is primarily influenced by the carbon content. Based on Table 3, the value is generally below 50\% (the carbon content of coals ranges from $80 \%$ to $92 \%$ ). The presence of hydrogen and sulphur are approximately the same, but in small quantities. The low sulphur content is favourable from an environmental perspective. However, the low hydrogen content is not beneficial in terms of calorific value. 
Table 3. Elemental composition and calorific value of biomass. (Sources: Tóth - Bulla Nagy, 2011 and Gergely, 2012)

\begin{tabular}{|l|c|c|c|c|c|c|c|c|}
\hline \multirow{2}{*}{$\begin{array}{c}\text { Type of } \\
\text { biomass }\end{array}$} & \multicolumn{4}{|c|}{ Chemical ingredients, \% } & $\begin{array}{c}\text { Heating } \\
\text { value }\end{array}$ & Ash & $\begin{array}{c}\text { Volatile } \\
\text { matter }\end{array}$ \\
\cline { 2 - 9 } & $\mathbf{C}$ & $\mathbf{H}$ & $\mathbf{O}$ & $\mathbf{N}$ & $\mathbf{S}$ & $\mathbf{M J} / \mathbf{k g}$ & $\mathbf{\%}$ & $\mathbf{\%}$ \\
\hline Wheat straw & 45 & 6 & 43 & 0.6 & 0.12 & 17.3 & 5.28 & 74 \\
\hline Corn stalk & 44 & 5.8 & 40 & 1.3 & 0.12 & 17.5 & 8.78 & 76 \\
\hline Wood & 47 & 6.3 & 46 & 0.16 & 0.02 & 18.5 & 0.52 & 85 \\
\hline Bark & 47 & 5.4 & 40 & 0.4 & 0.06 & 16.2 & 7.14 & 76 \\
\hline Wood with bark & 47 & 6 & 44 & 0.3 & 0.05 & 18.1 & 2.65 & 82 \\
\hline Miscanthus & 46 & 6 & 44 & 0.7 & 0.1 & 17.4 & 3.2 & 80 \\
\hline Canola oil & 77 & 12 & 11 & 0.1 & 0 & 26.9 & 0 & 100 \\
\hline Ethanol & 52 & 13 & 25 & 0 & 0 & 26.9 & 0 & 100 \\
\hline Methanol & 38 & 12 & 50 & 0 & 0 & 19.5 & 0 & 100 \\
\hline
\end{tabular}

Due to the fact that oxygen is utilized during combustion, the amount of produced gas is less than in the case of coal burning. The moisture content not only reduces the efficiency of calorific heating, but it also increases the amount of flue gas, which may cause a problem during the process because of condensation.

One important characteristic is high volatile matter content. For example, in the case of cereal straw, from the share of combustible substances (82-86\%), $70-80 \%$ is made up of volatile matter. They are released in large quantitates at the temperature of $250-300^{\circ} \mathrm{C}$ during the combustion process. This means that the material of the furnace need to be adaptable to material to be burnt, because in the case of incomplete combustion toxic $\mathrm{CO}$ is generated, less heat is released and the flue gases my contain combustible constituents.

Due to the combustion of volatile gases secondary air has to be imported to the furnace. If this is not done, as a result of incomplete combustion phenolic compounds, tar, etc. (are) is formed, which can be deposited on the boiler wall and in the chimney. In addition to CO, the flue gases of incomplete combustion contain large quantities of dust as well.

The variety of wood types for firing purposes is wide: firewood, logs, pine sawdust and sawmill by-products. The amount of energy recovered from wood can be characterized on the basis of heating value. The calorific value depends on the moisture content and on the species of wood, too.

Table 4. Heating value of the different tree species. (Source: Tóth - Bulla - Nagy, 2011)

\begin{tabular}{|l|l|}
\hline \multicolumn{1}{|c|}{ Wood species } & Heating value $(\mathbf{k j} / \mathbf{k g})$ \\
\hline Spruce & 19,478 \\
\hline Fir & 17,648 \\
\hline Larch & 16,612 \\
\hline \multicolumn{2}{|c|}{ Soft wood } \\
\hline Silver birch & 18,439 \\
\hline Oak & 18,176 \\
\hline Turkey oak & 18,135 \\
\hline
\end{tabular}




\begin{tabular}{|l|l|}
\hline Ash (Fraxinus) & 18,125 \\
\hline Maple & 17,774 \\
\hline Poplar & 17,497 \\
\hline Black locust & 17,485 \\
\hline Hornbeam & 17,464 \\
\hline Willow & 17,012 \\
\hline
\end{tabular}

The difference between the species on the basis of calorific value is negligible.

The moisture content and calorific value are inversely proportional. The more water is contained in the tree, the less the calorific value is since the water evaporates during the combustion process. The change of heating value regarding moisture content can be seen is Table 5.

Table 5. Change of heating value regarding moisture content. (Source: Tóth - Bulla - Nagy, 2011)

\begin{tabular}{|l|c|c|}
\hline \multicolumn{1}{|c|}{ The state of tree } & Moisture content & Heating value \\
\hline In the forest & $50-60 \%$ & $2.0 \mathrm{kWh} / \mathrm{kg}=7.1 \mathrm{MJ} / \mathrm{kg}$ \\
\hline Stored one summer long & $25-35 \%$ & $3.4 \mathrm{kWh} / \mathrm{kg}=12.2 \mathrm{MJ} / \mathrm{kg}$ \\
\hline Stored for several years & $15-25 \%$ & $2.0 \mathrm{kWh} / \mathrm{kg}=14.4 \mathrm{MJ} / \mathrm{kg}$ \\
\hline
\end{tabular}

The heat required for evaporation of water (approx. $2.5 \mathrm{MJ} / \mathrm{kg}$ ) occurs as a loss.

Table 6. Energetic characteristics of biomass fuels. (Source: Kocsis in Grassi - Collina Zibetta, 1990)

\begin{tabular}{|l|c|c|c|c|c|}
\hline & $\begin{array}{c}\text { Moisture } \\
\text { content } \\
\mathbf{\%}\end{array}$ & $\begin{array}{c}\text { Biomass yields } \\
\mathbf{t / h a}\end{array}$ & $\begin{array}{c}\text { Calorific value } \\
\mathbf{M J / k g}\end{array}$ & $\begin{array}{c}\text { Net heat* } \\
\text { equivalent } \\
\mathbf{k g O E} / \mathbf{k g}\end{array}$ & $\begin{array}{c}\text { Net energy* } \\
\text { density } \\
\mathbf{k g O E} / \mathbf{h a}\end{array}$ \\
\hline Cereal straw & $10-15$ & $1.5-3.5$ & $15.3-16.2$ & $0.29-0.31$ & $435-1085 \mathrm{HE}$ \\
\hline Rice straw & $20-25$ & $1.3-3.2$ & $13.5-14.4$ & $0.26-0.28$ & $338-986 \mathrm{HE}$ \\
\hline Sunflower stem & $25-30$ & $1.9-3.5$ & $12.4-13.5$ & $0.24-0.26$ & $456-910 \mathrm{HE}$ \\
\hline Corn stem & $30-40$ & $3.5-5.5$ & $10.2-12.4$ & $0.19-0.24$ & $665-1320 \mathrm{HE}$ \\
\hline Fuelwood & $15-25$ & $2.0-2.5$ & $13.5-15.3$ & $0.26-0.29$ & $520-725 \mathrm{HE}$ \\
\hline Forest residues & $25-30$ & $1.5-2.0$ & $12.4-13.5$ & $0.21-0.23$ & $311-451 \mathrm{HE}$ \\
\hline Short rot. chips & $25-35$ & $8.0-9.0$ & $11.3-13.5$ & $0.22-0.26$ & $1760-2610 \mathrm{HE}$ \\
\hline $\begin{array}{l}\text { Silage for } \\
\text { biogas }\end{array}$ & - & $8.0-9.0$ & $10.5-12.6$ & $0.22-0.26$ & $2000-2700 \mathrm{LF}$ \\
\hline Oilseed rape & - & $1.0-1.5$ & $35.6-36.8$ & $0.85-0.88$ & $850-1320 \mathrm{LF}$ \\
\hline Straw & $10-15$ & $3.0-4.0$ & $15.3-16.2$ & $0.29-0.31$ & $870-1240 \mathrm{LF}$ \\
\hline Bio-ethanol & - & $1.5-3.5$ & $25.1-27.1$ & $0.6-0.66$ & $900-2275 \mathrm{LF}$ \\
\hline
\end{tabular}

* Efficiency: 80\%; HE-Heat; LF-Liquid Fuels

Biomass energy sources are decentralized and cheap renewable energies suitable for direct combustion and, through many available technologies for conversion into more valuable secondary energy carriers, such as compacted solid fuels, liquid or gaseous bio-fuels and electricity. The transportation, storing and handling of biomass are much easier than those of other renewable energy sources, like solar, wind or geothermal energy. The calorific value of bone dry biomass $(17-18 \mathrm{MJ} / \mathrm{kg}$ or $0.41-0.43 \mathrm{kgOE} / \mathrm{kg}$ ) is equal to that of medium quality coal and, even air-dry biomass at 10-20\% moisture content has an energy equivalent of $0.3-$ $0.4 \mathrm{kgOE} / \mathrm{kg}$. 
Due to the low spatial net energy density, these energy sources can be used primarily for fulfilling the needs of small and medium performance power plants, which meet the local heat and electricity demands.

\section{References}

Alakangas, E. et. al. (2011). Solutions for biomass fuel market barriers and raw material availability: Summary of the EUBIONET III project results. EUBIONET III. Retrieved 2/02/2016, from http://www.eubionet.net/GetItem.asp?item=digistorefile;325123;1770\&params=open;gallery

Altawell, N. (2014). The Selection Process of Biomass Materials for the Production of BioFuels and Co-firing. Wiley.

Baskar, C., Baskar, S., \& Dhillon, R. S. (eds.) (2012). Biomass Conversion: The Interface of Biotechnology, Chemistry and Materials Science. Springer.

Bridgwater, A. V., \& Grassi, G. (eds.) (1991). Biomass Pyrolysis Liquids Upgrading and Utilization. Springer.

Bridgewater, A. (1996). Thermal biomass conversion and utilization - Biomass information system. ECS-EC-EAEC. Retrieved 2/02/2016, from http://bookshop.europa.eu/fi/thermalbiomass-conversion-and-utilization-pbCGNA16863/downloads/CG-NA-16-863-EN-

C/CGNA16863ENC_001.pdf;pgid=y8dIS7GUWMdSR0EAlMEUUsWb0000qnjsVakk;sid= Hjot2vQUUegt36cZ4uzfZYxGekrCVbXYmo=?FileName=CGNA16863ENC_001.pdf\&SKU=CGNA16863ENC PDF\&CatalogueNumber=CG-NA-16-863-EN-C

Brown, R. C. (ed.) (2011). Thermochemical Processing of Biomass: Conversion into Fuels, Chemicals and Power. Wiley.

BTG biomass technology group BV (2009). Guideline for Safe and Eco-friendly Biomass Gasification. BTG biomass technology group $B V$. Retrieved 2/02/2016, from http://www.gasification-guide.eu/gsg_uploads/documenten/D10_Final-Guideline.pdf

Chang, J. (ed.) (2010). Biomass to Renewable Energy Processes. CRC Press.

Chen, H. (2013). Gas Explosion Technology and Biomass Refinery. Springer.

Dahlquist, E. (ed.) (2012). Biomass as Energy Source: Resources, Systems and Applications. CRC Press.

Dahlquist, E. (ed.) (2013). Technologies for Converting Biomass to Useful Energy: Combustion, gasification, pyrolysis, torrefaction and fermentation. CRC Press.

Dzikuć, M., \& Łasiński, K. (2014). Technical and Economic Aspects of Biomass Co-Firing in Coal-Fired Boilers. International Journal of Applied Mechanics and Engineering, Volume 19, Issue 4, 849-855.

German Solar Energy Society (DGS) \& Ecofys (2004). Planning and Installing Bioenergy Systems: A Guide for Installers, Architects and Engineers. Routledge.

Gikonyo, B. (ed.) (2015). Fuel Production from Non-Food Biomass: Corn Stover. Apple Academic Press. 
Grassi, G.; Collina, A., \& Zibetta, H. (eds.) (1990). Biomass for Energy, Industry and Environment: 6th E.C. Conference. CRC Press.

Hakeem, K. R.; Mohammad, J., \& Alothman, O. Y. (eds.) (2015). Agricultural Biomass Based Potential Materials. Springer.

IRENA (2012). Biomass for Power Generation. IRENA Working Paper: Renewable Energy Technologies: Cost Analysis Series. Retrieved 2/02/2016, from https://www.irena.org/DocumentDownloads/Publications/RE_Technologies_Cost_AnalysisBIOMASS.pdf

Jansen, R. A. (2012). Second Generation Biofuels and Biomass: Essential Guide for Investors, Scientists and Decision Makers. Wiley.

Lee, K. T., \& Ofori-Boateng, C. (2013). Sustainability of Biofuel Production from Oil Palm Biomass. Springer.

Matovic, M. D. (ed.) (2013). Biomass Now - Cultivation and Utilization. InTech.

OECD (2004). Biomass and Agriculture: Sustainability, Markets and Policies. OECD Publishing.

Overend, R. P.; Milne, T. A., \& Mudge, L. K. (eds.) (1985). Fundamentals of Thermochemical Biomass Conversion. Elsevier.

Pappné Vancsó, J. (2010). A biomassza, mint energiaforrás hasznositási lehetőségei, különös tekintettel Magyarországra. PhD Thesis.

Reed, T. B., \& Das, A. (1988). Handbook of Biomass Downdraft Gasifier Engine Systems. The Biomass Energy Foundation Press.

Riva, G. et. al. (2012). Handbook on Renewable Energy Sources. ENER SUPPLY. Retrieved 2/02/2016, from http://www.ener-supply.eu/downloads/ENER_handbook_en.pdf

Rosillo-Calle, F.; Bajay, S. V. \& Rothman, H. (eds.) (2000). Industrial Uses of Biomass Energy: The Example of Brazil. CRC Press.

Rosillo-Calle, F.; de Groot, P.; Hemstock, S. L., \& Woods, J. (eds.) (2007). The Biomass Assessment Handbook: Bioenergy for a Sustainable Environment. Earthscan.

UNIDO (2014). Renewable Energy for Inclusive and Sustainable Industrial Development: The Case of Biomass Gasification. United Nations. Retrieved 2/02/2016, from https://www.unido.org/fileadmin/user_media_upgrade/What_we_do/Topics/Energy_access/G asification_FINAL.pdf

van Loo, S., \& Koppejan, J. (eds.) (2008). The Handbook of Biomass Combustion and Cofiring. Earthscan.

Vertès, A. A.; Qureshi, N.; Blaschek, H. P., \& Yukawa, H. (eds.) (2010). Biomass to Biofuels: Strategies for Global Industries. Wiley.

Walderon, K. (ed.) (2014). Advances in Biorefineries: Biomass and Waste Supply Chain Exploitation. Woodhead Publishing. 
Wichtmann, W., \& Wichmann, S. (2011). Environmental, Social and Economic Aspects of a Sustainable Biomass Production. Journal of Sustainable Energy \& Environment Special Issue, 77-81.

World Energy Council (2010). Sustainability Criteria for Biomass and Biofuels. World Energy Council. Retrieved 2/02/2016, from https://www.worldenergy.org/wpcontent/uploads/2012/10/PUB_Biofuels_Policies_Standards_and_Technologies_2010_Annex $\underline{8}$ _WEC.pdf

Xie, H., \& Gatherhood, N. (2013). The Role of Green Chemistry in Biomass Processing and Conversion. Wiley.

Zhu, J. Y.; Zhang, X., \& Pan, X. (eds.) (2011). Sustainable Production of Fuels, Chemicals, and Fibers from Forest Biomass. Oxford University Press. 


\section{MODULE 3: BIOMASS}

CHAPTER 1. Technical aspects.

Subchapter 1.3.: Calculations and design.

Dr. Zsolt Radics

Geolin Co., Hungary

Summary: In this section, a detailed-analysis of different biomass-based installations is presented from low scale to high scale, i.e. from woody biomass to biogas. There are a lot of approaches in literature regarding biomass utilization technics. In this regard, the types set down by Sjaak Van Loo and Jaap Koppejan are explained in the following ${ }^{1}$.

\section{Residential wood-burning appliances}

Wood fire has been used as a heat source for thousands of years. During that time, the methods for burning wood and other biomass have progressed from an open pit to very sophisticated, controlled combustion systems. A number of appliance types have been developed to provide central heating using furnaces or boilers, or more localized using stoves and fireplaces. The traditional batch-fired systems burning firewood have been augmented by systems designed to burn pelletized wood wastes, agricultural grains or woodchips. The pressure to develop systems which minimize air pollution and maximize heating efficiency has led to imaginative and innovative new designs.

Provided that firewood is grown in a sustainable manner and used in efficient combustion systems with insignificant hydrocarbon emissions, firewood is a renewable energy source. Already today, it is a significant heating source in most of the world. Due to its potential for being $\mathrm{CO}_{2}$ neutral, an increased use of small-scale combustion systems can have a significant impact on reducing greenhouse gas emissions.

The fuels in use are mainly wood logs, both soft wood and hard wood. In wood stoves and boilers, wood briquettes, wood pellets, peat, peat briquettes and coal briquettes are also used to some extent. Wood pellets are also used in specially designed pellet stoves and pellet boilers.

\section{Combustion technologies for industrial and district heating systems}

This section describes combustion systems of a nominal thermal capacity exceeding $100 \mathrm{~kW}$. These furnaces are generally equipped with mechanical or pneumatic fuel-feeding systems. Manual fuel-feeding is no longer customary due to high personnel costs and strict emission limits. Moreover, modern industrial combustion plants are equipped with process control systems supporting fully automatic system operation. In principle, the following combustion technologies can be distinguished:

- fixed bed combustion;

- fluidized bed combustion; and

\footnotetext{
${ }^{1}$ The figures are cited from 'The Handbook of Biomass Combustion and Co-firing', therefore all credit goes to the authors of the book in this regard.

"The European Commission support for the production of this publication does not constitute an endorsement of the contents which reflects the views only of the authors, and the Commission cannot be held responsible for any use which may be made of the information contained therein."
} 
- pulverized fuel combustion.

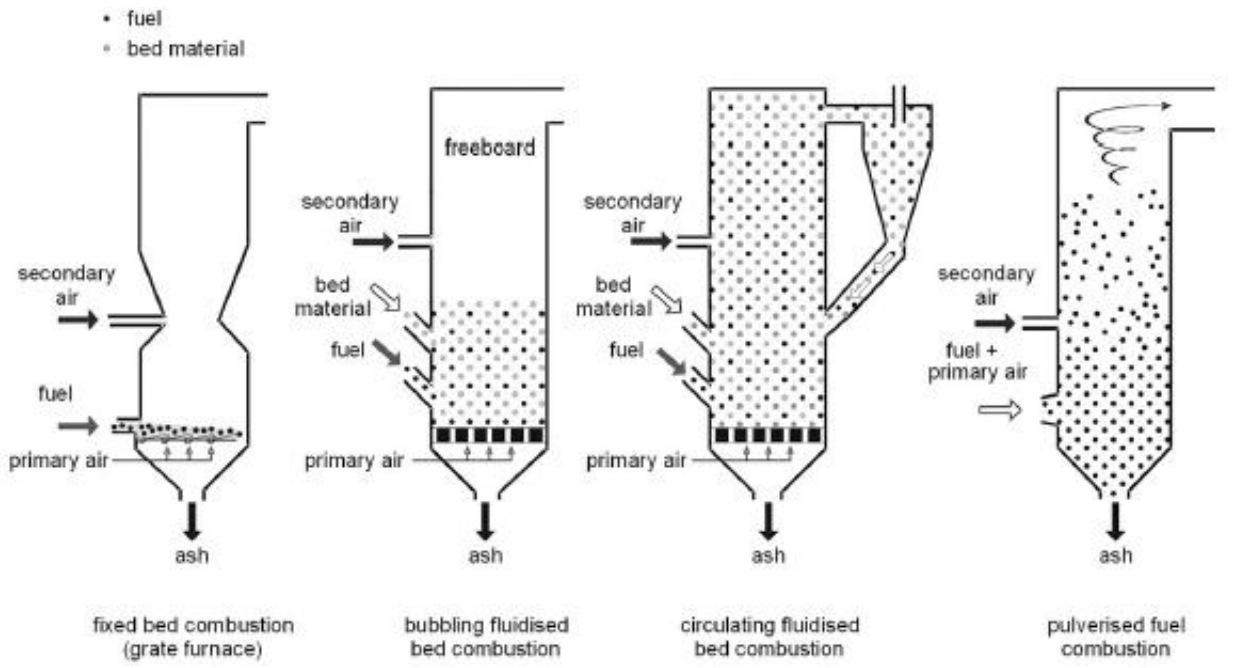

Figure 1. Principal combustion technologies for biomass. (Source: van Loo - Koppejan, 2008)

\section{Grate furnaces}

- There are various grate furnace technologies available: fixed grates, moving grates, travelling grates, rotating grates and vibrating grates.

- Grate furnaces are appropriate for biomass fuels with high moisture content, varying particle sizes (with a downward limitation concerning the amount of fine particles in the fuel mixture) and high ash content.

- Mixtures of wood fuels can be used, but current technology does usually not allow for mixtures of wood fuels and straw, cereals and grass, due to their different combustion behaviour, low moisture content and low ash-melting point.

- A well-designed and well-controlled grate guarantees a homogeneous distribution of the fuel and the bed of embers over the whole grate surface.

- The primary air supply must be divided into sections in order to be able to adjust the specific air amounts to the requirements of the zones where drying, gasification and charcoal combustion prevail.

- Staged combustion should be obtained by separating the primary and the secondary combustion chambers in order to avoid back-mixing of the secondary air and to separate gasification and oxidation zones

- Based on the flow directions of fuel and the flue gas, there are three systems of operation for grate combustion plants:

○ counter-current flow (flame in the opposite direction to the fuel);

- co-current flow (flame in the same direction as the fuel); and

$\circ$ cross-flow (flue gas removal in the middle of the furnace). 

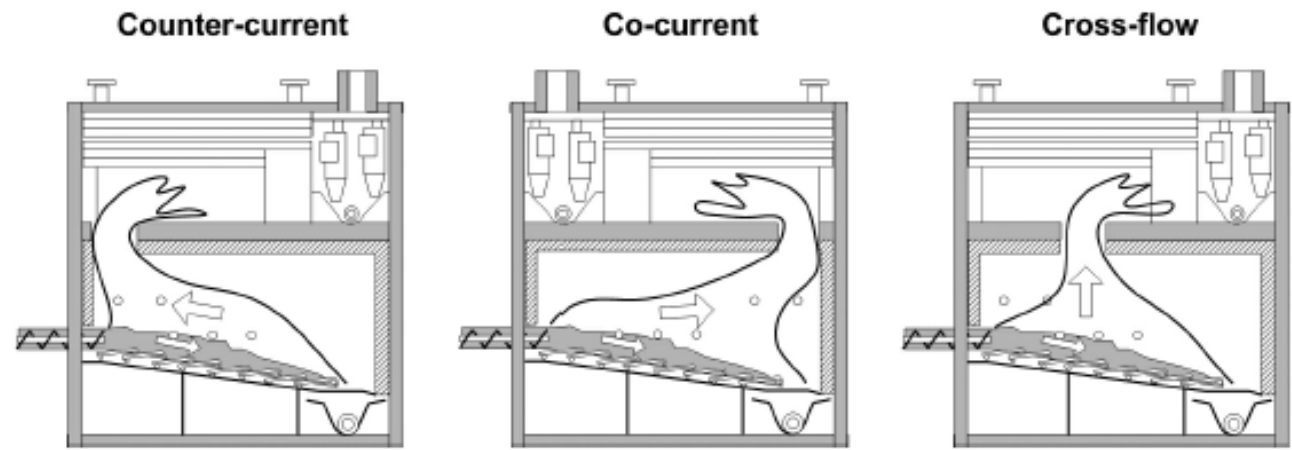

Figure 2. Classification of grate combustion technologies. (Source: van Loo - Koppejan, 2008)

\section{Underfeed stokers}

- Underfeed stokers represent a cheap and operationally safe technology for small and medium-scale systems up to a nominal boiler capacity of $6 \mathrm{MW}_{\text {th. }}$.

- The fuel is fed into the combustion chamber by screw conveyors from below and is transported upwards on an inner or outer grate.

- Outer grates are more common in modern combustion plants because they allow for more flexible operation and an automatic ash removing system can be applied more easily.

- Primary air is supplied through the grate, secondary air is usually supplied at the entrance to the secondary combustion chamber.

- Underfeed stokers are suitable for biomass fuels with low ash content (woodchips, sawdust, pellets) and small particle sizes (up to $50 \mathrm{~mm}$ ).

- Ash-rich biomass fuels such as bark, straw and cereals need more efficient ash removal systems.

- Moreover, sintered or melted ash particles covering the upper surface of the fuel bed can cause problems in underfeed stokers, due to unstable combustion conditions when the fuel and the air break through the ash-covered surface.

- An advantage of underfeed stokers is their good partial-load behaviour and their simple load control.

- Load changes can be achieved more easily and quickly than in grate combustion plants, because the fuel supply can be controlled more easily and the fuel mass in the furnace is comparatively low.

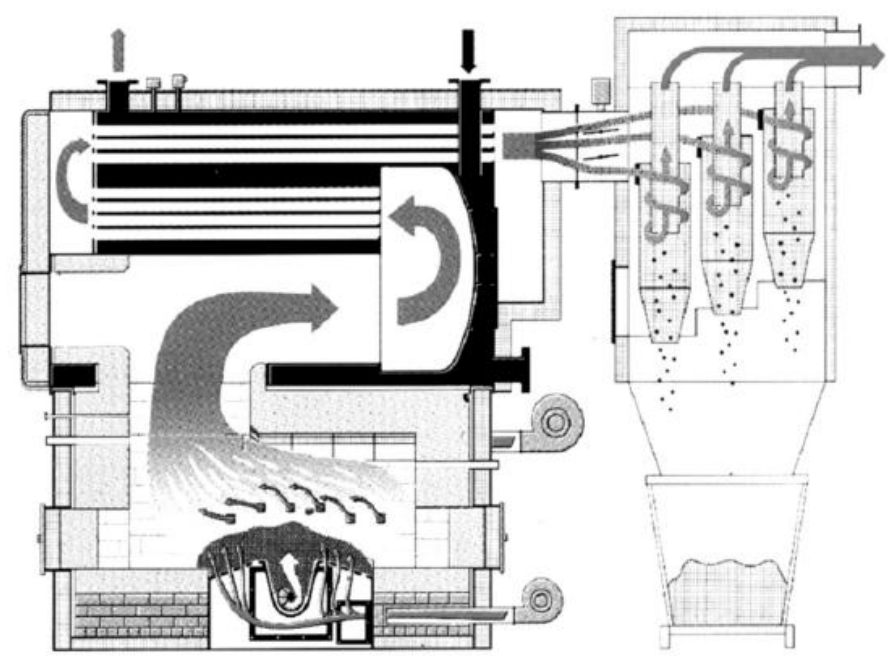

Figure 3. Underfeed stoker furnace. (Source: van Loo - Koppejan, 2008)

"The European Commission support for the production of this publication does not constitute an endorsement of the contents which reflects the views only of the authors, and the Commission cannot be held responsible for any use which may be made of the information contained therein." 


\section{Fluidized bed combustion}

- Fluidized bed combustion (FBC) systems have been applied since 1960 for combustion of municipal and industrial wastes.

- Since then, over 300 commercial installations have been built worldwide.

- Regarding technological applications, bubbling fluidized beds (BFB) and circulating fluidized beds (CFB) have to be distinguished (the following general features are characterizing both types).

- A fluidized bed consists of a cylindrical vessel with a perforated bottom plate filled with a suspension bed of hot, inert and granular material.

- The common bed materials are silica sand and dolomite.

- Primary combustion air enters the furnace from below through the air distribution plate and fluidizes the bed so that it becomes a seething mass of particles and bubbles.

- The intense heat transfer and mixing provides good conditions for complete combustion with low excess air demand.

- The combustion temperature has to be kept low (usually $650-900^{\circ} \mathrm{C}$ ) in order to prevent ash sintering in the bed.

- Due to the good mixing achieved, FBC plants can deal flexibly with various fuel mixtures (e.g. mixtures of different kinds of woody biomass fuels can be burned) but are limited when it comes to fuel particle size and impurities contained in the fuel.

- Therefore, an appropriate fuel pre-treatment system for particle size reduction and separation of metals is necessary for fail-safe operation.

- Fluidized bed combustion systems need a relatively long start-up time (approximately 8-15 hours) for which oil or gas burners are used.

- With regard to emissions, low NOx emissions can be achieved owing to good air staging, good mixing and a low requirement of excess air.

- One disadvantage of FBC plants is posed by the high dust loads entrained with the flue gas, which make efficient dust precipitators and boiler cleaning systems necessary.
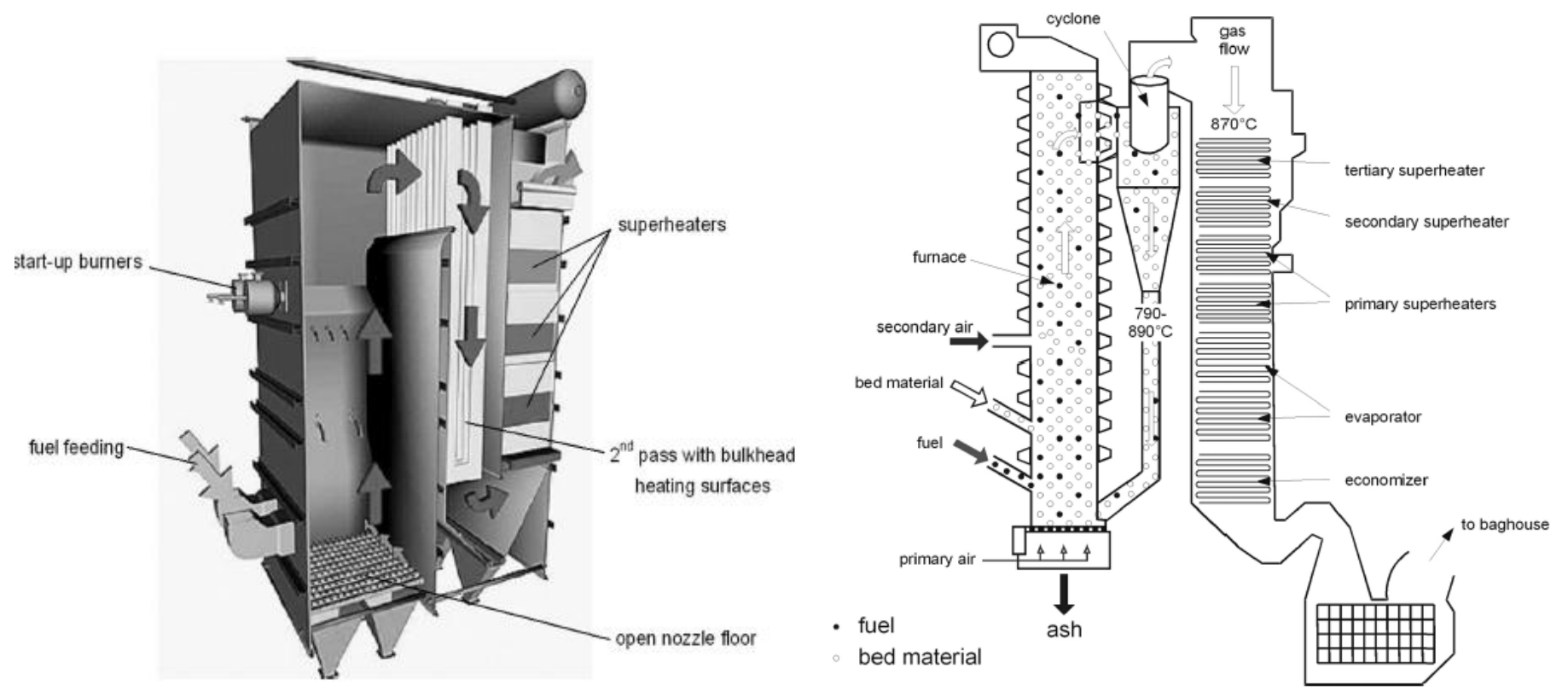

Figure 4. A BFB furnace (on the left) and a CFB furnace (on the right). (Source: van Loo - Koppejan, 2008) 


\section{Renewable energy for local development course}

Table 1. Overview of advantages, disadvantages and fields of application of various biomass combustion technologies. (Source: van Loo - Koppejan, 2008)

\begin{tabular}{|c|c|}
\hline Advantages & Disadvantages \\
\hline \multicolumn{2}{|l|}{ Grate furnaces } \\
\hline $\begin{array}{l}\text { - low investment costs for plants }<20 \mathrm{MW}_{\mathrm{th}} \\
\text { - low operating costs } \\
\text { - low dust load in the flue gas } \\
\text { - less sensitive to slagging than fluidized bed furnaces }\end{array}$ & $\begin{array}{l}\text { - usually no mixing of wood fuels and herbaceous } \\
\text { fuels possible (only special constructions can cope } \\
\text { with such fuel mixtures) } \\
\text { - efficient NOx reduction requires special } \\
\text { technologies (combination of primary and } \\
\text { secondary measures) } \\
\text { - high excess oxygen }(5-8 \text { vol\%) decreases } \\
\text { efficiency } \\
\text { - combustion conditions not as homogeneous as in } \\
\text { fluidized bed furnaces } \\
\text { - low emission levels at partial load operation require } \\
\text { a sophisticated process control }\end{array}$ \\
\hline \multicolumn{2}{|l|}{ Underfeed stokers } \\
\hline $\begin{array}{l}\text { - low investment costs for plants }<6 \mathrm{MW} \text { th } \\
\text { - simple and good load control due to continuous fuel } \\
\text { feeding and low fuel mass in the furnace } \\
\text { - low emissions at partial load operation due to good } \\
\text { fuel dosing } \\
\text { - low flexibility in regard to particle size }\end{array}$ & $\begin{array}{l}\text { - suitable only for biomass fuels with low ash content } \\
\text { and high ash-melting point (wood fuels) }(<50 \mathrm{~mm})\end{array}$ \\
\hline \multicolumn{2}{|l|}{ BFB furnaces } \\
\hline $\begin{array}{l}\text { - no moving parts in the hot combustion chamber } \\
\text { - NOx reduction by air staging works well } \\
\text { - high flexibility concerning moisture content and } \\
\text { kind of biomass fuels used } \\
\text { - low excess oxygen }(3-4 \text { Vol\%) raises efficiency and } \\
\text { decreases flue gas flow }\end{array}$ & $\begin{array}{l}\text { - high investment costs, interesting only for plants }> \\
20 \mathrm{MW}_{\text {th }} \\
\text { - high operating costs } \\
\text { - reduced flexibility with regard to particle size }(<80 \\
\mathrm{mm}) \\
\text { - utilization of high alkali biomass fuels (e.g. straw) } \\
\text { is critical due to possible bed agglomeration } \\
\text { without special measures } \\
\text { - high dust load in the flue gas } \\
\text { - loss of bed material with the ash without special } \\
\text { measures }\end{array}$ \\
\hline \multicolumn{2}{|l|}{ CFB furnaces } \\
\hline $\begin{array}{l}\text { - no moving parts in the hot combustion chamber } \\
\text { - NOx reduction by air staging works well } \\
\text { - high flexibility concerning moisture content and } \\
\text { kind of biomass fuels used } \\
\text { - homogeneous combustion conditions in the furnace } \\
\text { if several fuel injectors are used } \\
\text { - high specific heat transfer capacity due to high } \\
\text { turbulence } \\
\text { - use of additives easy } \\
\text { - very low excess oxygen }(1-2 \mathrm{vol} \%) \text { raises efficiency } \\
\text { and decreases flue gas flow }\end{array}$ & $\begin{array}{l}\text { - high investment costs, interesting only for plants }> \\
30 \mathrm{MW}_{\text {th }} \\
\text { - high operating costs } \\
\text { - low flexibility with regard to particle size ( }<40 \\
\text { mm) } \\
\text { - utilization of high alkali biomass fuels (e.g. straw) } \\
\text { is critical due to possible bed agglomeration } \\
\text { - high dust load in the flue gas } \\
\text { - loss of bed material with the ash without special } \\
\text { measures } \\
\text { - high sensitivity concerning ash slagging }\end{array}$ \\
\hline
\end{tabular}

\section{Power generation and co-generation}

Power generation by combustion can be mainly divided into closed thermal cycles and open processes.

In closed thermal cycles, among which the steam turbine is the most important application, the combustion process and the power generation cycle are physically separated by a heat transfer from the hot combustion gas to a process medium used in a secondary cycle. Thanks

"The European Commission support for the production of this publication does not constitute an endorsement of the contents which reflects the views only of the authors, and the Commission cannot be held responsible for any use which may be made of the information contained therein." 
to the separation between fuel and engine, the engine is solely in contact with a clean process medium and thus undesired elements in the fuel and flue gas such as fly-ash particles cannot cause damage to the engine. Hence closed cycles are well suited for solid fuels and widely applied for power production from coal, biomass and municipal solid waste.

Open processes are commonly applied for gaseous and liquid fuels used in internal combustion engines and gas turbines. The fuel is burned either directly inside an internal combustion engine, which is operated cyclically as a four-stroke or two-stroke engine, or it is burned continuously in an external combustion chamber and then led through an open gas turbine for expansion. The use of solid fuels in internal combustion engines is technically not feasible and their application in open gas turbines is regarded as complex. Nevertheless, two technologies for the direct use of biomass are being considered in open gas turbines:

- Directly-fired gas turbines by pressurized combustion of pulverized biomass with consecutive expansion of the purified flue gas to atmosphere in a gas turbine,

- Directly-fired gas turbines by atmospheric combustion of pulverized biomass with expansion of the purified flue gas to vacuum, followed by gas cooling and a compression of the cold gas to enable gas exhaust to the atmosphere.

\section{Closed thermal cycles for power production}

The processes and engine types are:

- Steam turbines and steam engines used as expansion engines in the Rankine cycle, where water is evaporated under pressure to high-pressure steam that is then expanded to low pressure in the expansion engine.

- Steam turbines used in an Organic Rankine cycle (ORC) with use of an organic medium instead of water, used in a tertiary cycle separated from the heat production (the combustion heat is transferred to a thermal oil in the boiler which is fed to an external evaporator for the organic medium with a lower boiling temperature than water).

- Stirling engines (indirectly fired gas engines using the Stirling cycle) which are driven by a periodic heat exchange from the flue gas to a gaseous medium such as air, helium or hydrogen.

- Closed gas turbines using a closed cycle with air, helium or hydrogen which is compressed, heated, and then expanded to drive a turbine as an expansion engine (similar to a Stirling engine).

- Closed gas turbines using a heat transfer to compressed air, which is expanded in a gas turbine as an expansion engine and then fed to the boiler as combustion air (hence the thermodynamic cycle corresponds to a closed gas turbine, although the mass flow through the gas turbine is not physically closed).

Table 2. Closed processes for power production by biomass combustion. (Source: van Loo Koppejan, 2008)

\begin{tabular}{|l|l|l|l|}
\hline \multicolumn{1}{|c|}{ Working medium } & \multicolumn{1}{c|}{ Engine type } & \multicolumn{1}{c|}{ Typical size } & \multicolumn{1}{c|}{ Status } \\
\hline \multirow{5}{*}{$\begin{array}{l}\text { Liquid and vapour (with } \\
\text { phase change) }\end{array}$} & Steam turbine & $500 \mathrm{kWe}-500 \mathrm{MWe}$ & Proven technology \\
\cline { 2 - 4 } & Steam piston engine & $25 \mathrm{kWe}-1.5 \mathrm{MWe}$ & Proven technology \\
\cline { 2 - 4 } & Steam screw engine & $\begin{array}{l}\text { Not established, } \\
\text { estimated range from } \\
500 \mathrm{kWe}-2 \mathrm{MWe}\end{array}$ & $\begin{array}{l}\text { One demonstration plant } \\
\text { with 730kWe and turbine } \\
\text { from commercial screw } \\
\text { compressor }\end{array}$ \\
\cline { 2 - 4 } & Steam turbine with & $400 \mathrm{kWe}-1.5 \mathrm{MWe}$ & Some commercial plants \\
\hline
\end{tabular}




\begin{tabular}{|l|l|l|l|}
\hline & organic medium (ORC) & with biomass \\
\hline \multirow{2}{*}{$\begin{array}{l}\text { Gas (without phase } \\
\text { change) }\end{array}$} & $\begin{array}{l}\text { Closed gas turbine (hot } \\
\text { air turbine) }\end{array}$ & $\begin{array}{l}\text { Not established, similar } \\
\text { size as steam turbine, } \\
\text { probably large due to cost } \\
\text { and efficiency }\end{array}$ & $\begin{array}{l}\text { Concept and } \\
\text { development }\end{array}$ \\
\cline { 2 - 4 } & Stirling engine & $1 \mathrm{kWe}-100 \mathrm{kWe}$ & Development and pilot \\
\hline
\end{tabular}

\section{Co-combustion}

Increasing concerns about the environmental impacts of power generation from fossil fuels have prompted the development of more sustainable means of generating power. These have included increasing the fraction of renewable and sustainable energy in the national energy supply. Historically, renewable energy sources have struggled to compete with fossil energy, due to their relatively high costs, and high technical risk.

The co-firing of biomass with coal in conventional coal-fired boilers can provide a reasonably attractive option for the utilization of biomass for the generation of power, and in some cases heat. Co-firing makes use of the extensive infrastructure associated with the existing fossil fuel-based power systems, and requires only relatively modest additional capital investment. In most countries, the co-firing of biomass is one of the most economic technologies available for providing significant $\mathrm{CO}_{2}$ reductions.

Overall, the principal driver for the increasing demand for the capability to co-fire biomass materials in new and existing coal boiler plants is therefore that co-firing is regarded as representing a very attractive option for biomass utilization, and for the delivery of renewable energy, in terms of the capital investment requirement, security of supply, power generation efficiency and generation cost.

The great majority of biomass co-firing worldwide is carried out in large pulverized coal power boilers, and the focus in this section is very much on this type of plant. The basic cofiring options relevant to pulverized coal-fired power plants can be categorized as follows:

- direct co-firing, which involves the direct feeding of the biomass to the coal firing system or the furnace.

- indirect co-firing, which involves the gasification of the biomass and the combustion of the product fuel gas in the furnace.

- parallel combustion, which involves the combustion of the biomass in a separate combustor and boiler and the utilization of the steam produced within the coal plant steam and power generation systems.

\section{$\underline{1 .}$ Direct co-firing}

The direct co-firing approach can be implemented in a number of ways. The first option involves mixing the bio-fuel with the coal upstream of the coal feeders, and generally within the coal conveying system. The mixed fuel is then processed through the installed coal milling and firing system. This is the simplest option and involves the lowest capital cost. This approach has been applied widely for co-firing biomass materials in granular, pelletized and dust forms, generally at relatively low co-firing ratios.

The second option involves separate handling, metering, and comminution of the biofuel and injection into the pulverized fuel pipework upstream of the burners or at the burners. This option can permit co-firing at elevated levels. 
The third option involves the separate handling and comminution of the bio-fuel with combustion through a number of dedicated burners. This approach involves significant modification of the combustion equipment and the furnace, and represents the highest capital cost direct co-firing option. It is, in principle, possible to inject the pre-milled biomass into the upper furnace as a reburn fuel for NOx emission control. However, this option needs significant further development prior to full scale implementation. Some test work has been carried out in small scale test facilities.

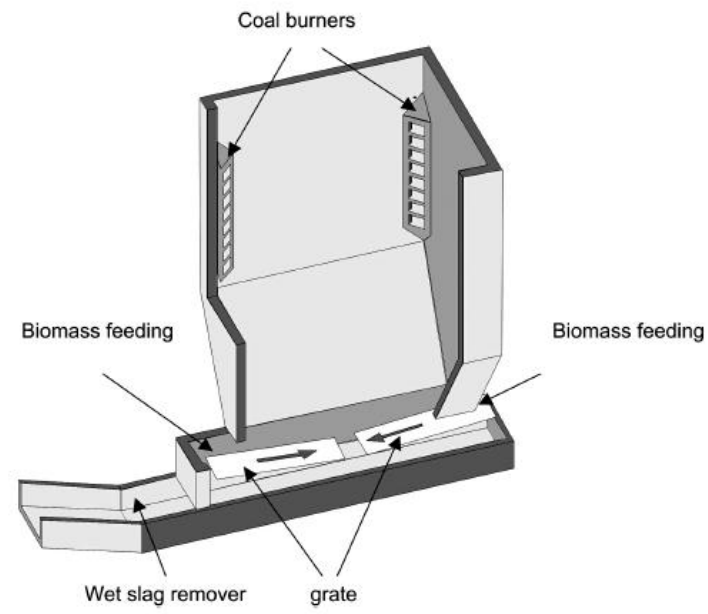

Figure 5. Biomass co-firing system at St Andrea, Austria. (Source: van Loo - Koppejan, 2008)

\section{Indirect co-firing}

The indirect co-firing approach is based on the gasification of biomass, with the product fuel gas being combusted directly in the coal-fired furnace. The main product of the gasification process is a low calorific value fuel gas, with the calorific value depending principally on the moisture content of the fuel. The other major products are:

- all of the biomass ash materials, including the alkali metals and trace metals,

- the tars and other condensable organic species,

- the $\mathrm{Cl}, \mathrm{N}$ and $\mathrm{S}$ species.

In terms of the nature and cost of the installed equipment, the indirect co-firing is equivalent to the replacement of the comminution equipment by a gasifier, i.e. the gasifier can be regarded as being a form of bio-fuel pre-processing. On the scale of operation relevant to most utility boiler co-firing projects, the preferred systems for biomass gasification are airblown, atmospheric pressure, circulating fluidized beds. There are a number of gasification technologies of this type, from a number of suppliers, in demonstration or commercial operation. One of the key issues with indirect co-firing approach is the degree of the fuel gas cleaning prior to co-combustion in the coal-fired furnace.

\section{$\underline{\text { 3. Parallel co-firing }}$}

Parallel firing involves the installation of a separate combustor and boiler for the biomass to produce steam which, in turn, is used in the coal-fired power plant steam circuit. Although parallel firing installations involve significantly higher capital investment than direct cocombustion systems, they may have advantages such as the possibility to use relatively difficult fuels with high alkali metal and chlorine contents and the production of separate coal and biomass ash streams. 


\section{References}

Baskar, C., Baskar, S., \& Dhillon, R. S. (eds.) (2012). Biomass Conversion: The Interface of Biotechnology, Chemistry and Materials Science. Springer.

BERC (2011). Particulate Matter Emissions-Control Options for Wood Boiler Systems. Biomass Energy Resource Center. Retrieved 2/02/2016, from http://www.biomasscenter.org/images/stories/FSE_PM_Emissions.pdf

Brown, R. C. (ed.) (2011). Thermochemical Processing of Biomass: Conversion into Fuels, Chemicals and Power. Wiley.

BTG biomass technology group BV (2009). Guideline for Safe and Eco-friendly Biomass Gasification. BTG biomass technology group $B V$. Retrieved 2/02/2016, from http://www.gasification-guide.eu/gsg_uploads/documenten/D10_Final-Guideline.pdf

Chang, J. (ed.) (2010). Biomass to Renewable Energy Processes. CRC Press.

Chen, H. (2013). Gas Explosion Technology and Biomass Refinery. Springer.

Dahlquist, E. (ed.) (2012). Biomass as Energy Source: Resources, Systems and Applications. CRC Press.

Dahlquist, E. (ed.) (2013). Technologies for Converting Biomass to Useful Energy: Combustion, gasification, pyrolysis, torrefaction and fermentation. CRC Press.

Floc'h-Laizet, C. \& Pennequin, J. (2010). Guide for connecting several houses to a micro heating network. Biomasse Normandie. Retrieved 2/02/2016, from http://www.biohousing.eu.com/GetItem.asp?item=file;4980

German Solar Energy Society (DGS) \& Ecofys (2004). Planning and Installing Bioenergy Systems: A Guide for Installers, Architects and Engineers. Routledge.

Jansen, R. A. (2012). Second Generation Biofuels and Biomass: Essential Guide for Investors, Scientists and Decision Makers. Wiley.

Matovic, M. D. (ed.) (2013). Biomass Now-Sustainable Growth and Use. InTech.

Rosillo-Calle, F.; Bajay, S. V. \& Rothman, H. (eds.) (2000). Industrial Uses of Biomass Energy: The Example of Brazil. CRC Press.

Rosillo-Calle, F.; de Groot, P.; Hemstock, S. L., \& Woods, J. (eds.) (2007). The Biomass Assessment Handbook: Bioenergy for a Sustainable Environment. Earthscan.

van Loo, S., \& Koppejan, J. (eds.) (2008). The Handbook of Biomass Combustion and Cofiring. Earthscan.

Walderon, K. (ed.) (2014). Advances in Biorefineries: Biomass and Waste Supply Chain Exploitation. Woodhead Publishing. 


\title{
MODULE 3: BIOMASS
}

CHAPTER 2. Economic aspects.

Subchapter 2.1.: Estimation cost of the investment (materials, installations, spatial planning).

\author{
Dr. Zsolt Radics \\ Geolin Co., Hungary
}

Summary: In this chapter, students get familiar with the most important costs associated to a biomass power plant installation: feedstock prices and power generating technology costs. In addition to the calculation of levelized cost of electricity, the students learn to calculate different economic standards and indexes to decide whether a biomass power plant is costefficient. The subchapter is widely concerned with the levelized cost of electricity, costs of different biomass power generating technologies, feedstock prices and technology costs. The last part presents the costs of a biomass combustion plant.

\section{Introduction.}

Given the many options available, the cost of bioenergy systems cannot be easily summarized in the way in which other renewables, such as wind and solar, can be. In some cases regarding biomass, costs are expected to come down considerably once large-scale systems are commercialized. Also note that performance changes with the quality of biomass supply, a fact that impacts the exploitation costs. For example, in some cases the incineration of waste wood results in lower efficiency due to the considerable variation in the combustion properties of wastes and the difficulty of controlling these variations during operation.

\section{Levelized cost of electricity}

As described in the previous module, the levelized cost of electricity (LCOE), also known as Levelized Energy Cost (LEC), is the net present value of the unit-cost of electricity over the lifetime of a generating asset. It is often taken as a proxy for the average price that the generating asset must receive in a market to break even over its lifetime. It is a first-order economic assessment of the cost competitiveness of an electricity-generating system that incorporates all costs over its lifetime: initial investment, operations and maintenance, cost of fuel, cost of capital.

The LCOE is that value for which an equal-valued fixed revenue delivered over the life of the asset's generating profile would cause the project to break even. This can be roughly calculated as the net present value of all costs over the lifetime of the asset divided by the total electrical energy output of the asset. Then, it is given by:

$$
L C O E=\frac{\text { sum of costs over lifetime }}{\text { sum of electrical energy produced over lifetime }}
$$


where:

$$
L C O E=\frac{\sum_{t=1}^{n} \frac{I_{t}+M_{t}+F_{t}}{(1+r)^{t}}}{\sum_{t=1}^{n} \frac{E_{t}}{(1+r)^{t}}}
$$

$I_{t}$ : investment expenditures in the year $\mathrm{t}$

$M_{t}$ : operations and maintenance expenditures in the year $\mathrm{t}$

$F_{t}$ : fuel expenditures in the year $\mathrm{t}$

$E_{t}$ : electrical energy generated in the year $\mathrm{t}$

$r$ : discount rate

$n$ : expected lifetime of system or power station

Although different cost measures are useful in different situations, the LCOE of renewable energy technologies is a widely used measure by which renewable energy technologies can be evaluated for modelling or policy development purposes.

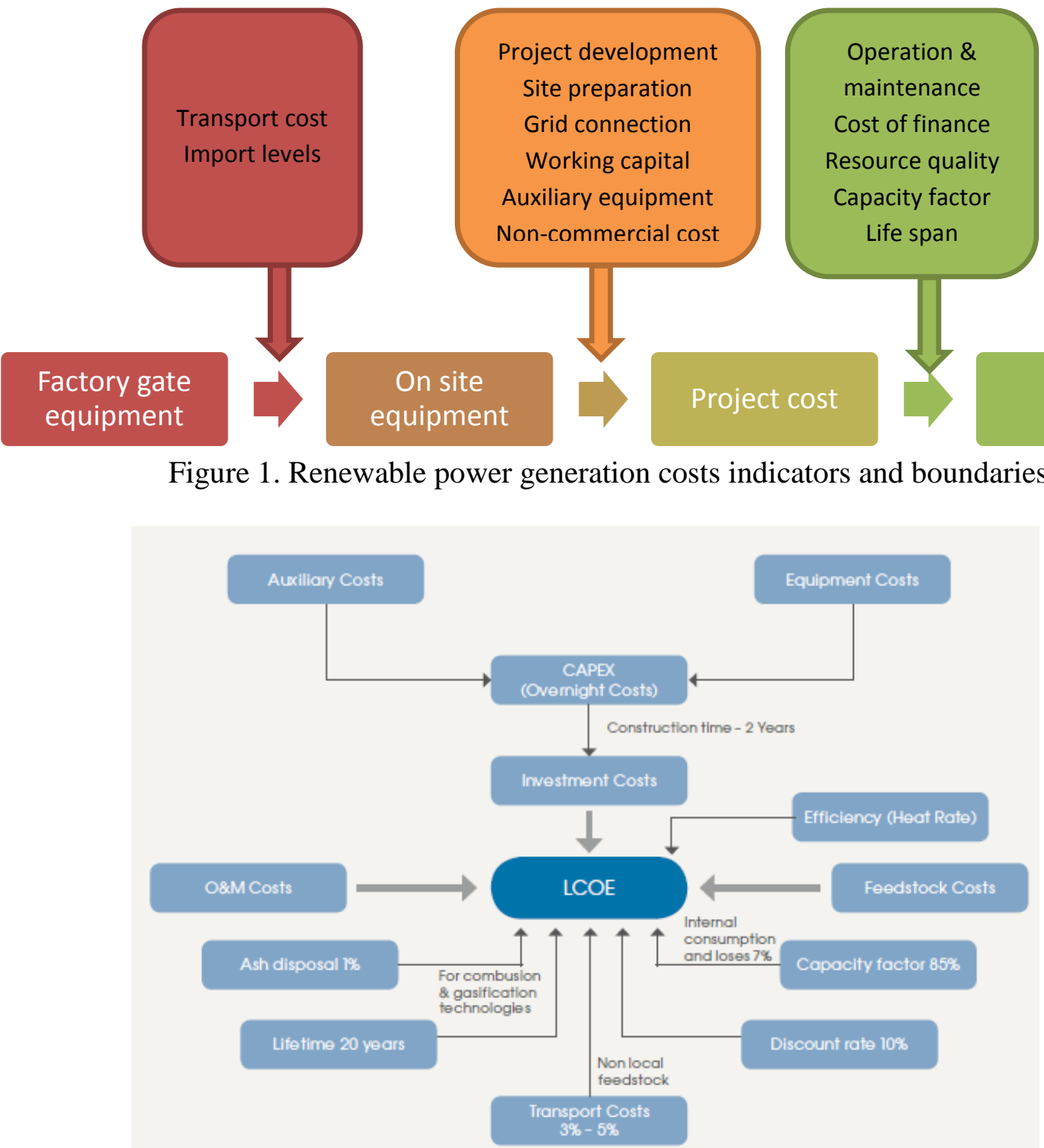

Figure 2. The LCOE framework for biomass power generation (Source: IRENA, 2012)

"The European Commission support for the production of this publication does not constitute an endorsement of the contents which reflects the views only of the authors, and the Commission cannot be held responsible for any use which may be made of the information contained therein." 
Figure 1 and 2 show the renewable power generation costs indicators and boundaries and the framework for biomass power generation related to LCOE. Figure 1 also reveals the occurrence of different costs in addition to the main boundaries and processes in connection with LCOE, while Figure 2 is more concerned with the financial characteristics and the features, and the extent of costs.

\section{Costs of different biomass power generating technologies}

The total installed costs of biomass power generation technologies varies significantly by technology and country. The total installed costs of stoker boilers were between 1,700 $€$ and $3,830 € / \mathrm{kW}$ in 2010 , while those of circulating fluidised bed boilers were between 1,950€ and $4,050 € / \mathrm{kW}$. Anaerobic digester power systems had capital costs between $2,300 €$ and $5,500 € / \mathrm{kW}$. Gasification technologies, including fixed bed and fluidised bed solutions, had total installed capital costs ranged between $1,920 €$ and $5,130 € / \mathrm{kW}$. Co-firing biomass at low-levels in existing thermal plants typically requires additional investments of $360 €$ to 540 $€ / \mathrm{kW}$. Using landfill gas for power generation has capital costs ranged between $1,720 €$ and $2,200 € / \mathrm{kW}$. The cost of CHP plants is significantly higher than for the electricity-only configuration.

Table 1. Typical capital costs and levelized costs of electricity of biomass power technologies (Source: IRENA, 2012).

\begin{tabular}{|l|c|c|}
\hline & Investment costs $(\boldsymbol{€} / \mathbf{k W})$ & LCOE range $(\boldsymbol{€} / \mathbf{k W h})$ \\
\hline Stoker boiler & $1,700-3,830$ & $0.05-0.19$ \\
\hline $\begin{array}{l}\text { Bubbling and circulating } \\
\text { fluidised boilers }\end{array}$ & $1,950-4,050$ & $0.06-0.19$ \\
\hline $\begin{array}{l}\text { Fixed and fluidised bed } \\
\text { gasifiers }\end{array}$ & $1,920-5,130$ & $0.06-0.21$ \\
\hline Stoker CHP & $3,200-6140$ & $0.06-0.26$ \\
\hline Gasifier CHP & $5,000-5,890$ & $0.10-0.25$ \\
\hline Landfill gas & $1,720-2,200$ & $0.08-0.11$ \\
\hline Digesters & $2,300-5,500$ & $0.05-0.13$ \\
\hline Co-firing & $125-765$ & $0.03-0.11$ \\
\hline
\end{tabular}

Many biomass power generation options are mature, commercially available technologies (e.g. direct combustion in stoker boilers, low-percentage co-firing, anaerobic digestion, municipal solid waste incineration, landfill gas, and combined heat and power). While others are less mature and only at the beginning of their deployment (e.g. atmospheric biomass gasification and pyrolysis), still others are only at the demonstration or R\&D phases (e.g. integrated gasification combined cycle, bio-refineries, bio-hydrogen). The potential for cost reductions is therefore very heterogeneous. Only marginal cost reductions are anticipated in the short-term, but the long-term potential for cost reductions from the technologies that are not yet widely deployed is good.

Table 2 presents investment costs for stationary applications of commercial systems using combustion or gasification for heat $\left(\mathrm{MW} / \mathrm{kW}_{\text {thermal }}\right)$ and power $\left(\mathrm{MW} / \mathrm{kW}_{\text {electrical }}\right)$. 
Table 2. Summary of estimated efficiencies, costs and deployment of bioenergy systems (Source: FAO 2010 based on Faiij, 2006).

\begin{tabular}{|c|c|c|c|c|c|}
\hline $\begin{array}{l}\text { Process or } \\
\text { method }\end{array}$ & Applications & $\begin{array}{l}\text { Capacity } \\
\text { range }\end{array}$ & $\begin{array}{c}\text { Net efficiency } \\
\text { (lower heating } \\
\text { value) }(\%) \\
\end{array}$ & Investment cost & $\begin{array}{l}\text { Deployment } \\
\text { status }\end{array}$ \\
\hline \multicolumn{6}{|l|}{ Combustion } \\
\hline Heat & $\begin{array}{l}\text { Domestic } \\
\text { (modern } \\
\text { furnace) }\end{array}$ & $1-5 \mathrm{MW}_{\text {th }}$ & $65-90$ & $300-700 € / \mathrm{kW}_{\text {th }}$ & $\begin{array}{l}\text { Increasing use of } \\
\text { modern furnaces } \\
\text { and prepared } \\
\text { biomass (pellets) }\end{array}$ \\
\hline $\begin{array}{l}\text { Combined heat } \\
\text { and power }\end{array}$ & $\begin{array}{l}\text { District heating, } \\
\text { industrial uses }\end{array}$ & $1-10 \mathrm{MW}_{\mathrm{e}}$ & $\begin{array}{l}80-100 \\
\text { (system) }\end{array}$ & $1500-2000 € / \mathrm{kW}_{\mathrm{e}}$ & $\begin{array}{l}\text { Widely deployed } \\
\text { in Europe and } \\
\text { North America }\end{array}$ \\
\hline \multirow[t]{2}{*}{ Stand-alone } & $\begin{array}{l}\text { Waste } \\
\text { incineration }\end{array}$ & $20-100 \mathrm{~s} \mathrm{MW}_{\mathrm{e}}$ & $\begin{array}{l}20-30 \\
\text { (electrical) }\end{array}$ & $2000-2500 € / \mathrm{kW}_{\mathrm{e}}$ & $\begin{array}{l}\text { Low efficiency } \\
\text { for mass burning/ } \\
\text { incineration }\end{array}$ \\
\hline & $\begin{array}{l}\text { High-efficiency } \\
\text { designs }\end{array}$ & 20-100s $\mathrm{MW}_{\mathrm{e}}$ & $\begin{array}{l}30-40 \\
\text { (electrical) }\end{array}$ & $1500-2000 € / \mathrm{kW}_{\mathrm{e}}$ & $\begin{array}{l}\text { Widely used in } \\
\text { northern Europe }\end{array}$ \\
\hline Co-firing & $\begin{array}{l}\text { Existing coal } \\
\text { plants }\end{array}$ & 5-20 $\mathrm{MW}_{\mathrm{e}}$ & $\begin{array}{l}30-40 \\
\text { (electrical) }\end{array}$ & $\begin{array}{l}\sim 250 € / \mathrm{kW}_{\mathrm{e}}+ \\
\text { cost of existing } \\
\text { plant }\end{array}$ & Widely deployed \\
\hline \multicolumn{6}{|l|}{ Gasification } \\
\hline Heat & Small-scale & $<1 \mathrm{MW}_{\text {th }}$ & $\begin{array}{l}\text { 60-90 } \\
\text { (system) }\end{array}$ & $200-600 € / \mathrm{kW}_{\text {th }}$ & $\begin{array}{l}\text { Commercially } \\
\text { deployed }\end{array}$ \\
\hline $\begin{array}{l}\text { Combined-heat- } \\
\text { and- } \\
\text { power gas } \\
\text { engine }\end{array}$ & Small-scale & $<1 \mathrm{MW}_{\mathrm{e}}$ & $15-30$ & $1000-3000 € / \mathrm{kW}_{\mathrm{e}}$ & $\begin{array}{l}\text { Limited } \\
\text { deployment }\end{array}$ \\
\hline \multirow{2}{*}{$\begin{array}{l}\text { Biomass } \\
\text { gasification } \\
\text { combined-cycle }\end{array}$} & & $30-100 \mathrm{MW}_{\mathrm{e}}$ & $40-50$ & $5000-6000 € / \mathrm{kW}_{\mathrm{e}}$ & $\begin{array}{l}\text { Demonstration } \\
\text { phase at smaller } \\
\text { scales }\end{array}$ \\
\hline & & $30-100 \mathrm{MW}_{\mathrm{e}}$ & $40-50$ & $1000-2000 € / \mathrm{kW}_{\mathrm{e}}$ & $\begin{array}{l}\text { Large-scale } \\
\text { (long-term) }\end{array}$ \\
\hline
\end{tabular}

Notes: $\mathrm{kWe}=$ kilowatts $_{\text {electical }} ; \mathrm{kW}$ th $=$ kilowatts $_{\text {thermal }} ; \mathrm{MWe}=$ megawatts $_{\text {electrical }} ; \mathrm{MW}$ th $=$ megawatts $_{\text {thermal }}$

\section{$\underline{\text { Feedstock prices }}$}

Unlike wind, solar and hydro, biomass electricity generation requires a feedstock that must be produced, collected, transported and stored. The economics of biomass power generation are critically dependent upon the availability of a secure, long term supply of an appropriate biomass feedstock at a competitive cost.

Secure, long-term supplies of low-cost, sustainably-sourced feedstocks are critical to the economics of biomass power plants. Feedstock costs can be zero for wastes which would otherwise have disposal costs or that are produced onsite at an industrial installation (e.g. black liquor at pulp and paper mills or bagasse at sugar mills). Feedstock costs may be modest where agricultural residues can be collected and transported over short distances. However, feedstock costs can be high where significant transport distances are involved due to the low energy density of biomass (e.g. the trade in wood chips and pellets). The analysis in this subchapter examines feedstock costs of between $9 € /$ tonne for low cost residues to 145 $€ /$ tonne for internationally traded pellets.

Feedstock costs can represent $40 \%$ to $50 \%$ of the total cost of electricity produced. The density of the forestry arisings has a direct impact on the radius of transport required to deliver a given energy requirement for a plant. The low energy density of biomass feedstocks 
tends to limit the transport distance from a biomass power plant that it is economical to transport the feedstock. This can place a limit on the scale of the biomass power plant, meaning that biomass struggles to take advantage of economies of scale in the generating plant because large quantities of low-cost feedstock are not available.

Prices for biomass sourced and consumed locally are difficult to obtain and no time series data on a comparable basis are available. Prices paid will depend on the energy content of the fuel, its moisture content and other properties that will impact the costs of handling or processing at the power plant and their impact on the efficiency of generation. The delivered cost will be considerably lower in most developing countries due to low labour costs but logistics and transport will tend to be uncertain and/or more expensive. In the case of co-firing at coal plants, the woody biomass feedstock can be compared directly. Under stand-alone comparisons, however, the investment costs will be considerably lower for coal and therefore there will need to be other considerations or other sources of support based on factors such as carbon finance, a preference for smaller scale or, in the case of imported coal, concerns about energy security. Table 3 presents price estimates for biomass feedstocks in the United States.

Table 3. Biomass feedstock prices and characteristics in the United States (Source: IRENA, 2012 based on EPA, 2007).

\begin{tabular}{|c|c|c|c|c|c|}
\hline & $\begin{array}{c}\text { Typical } \\
\text { moisture } \\
\text { content }\end{array}$ & $\begin{array}{c}\text { Heat value } \\
\text { MJ / kg } \\
\text { (LHV) }\end{array}$ & $\begin{array}{c}\text { Price } \\
\text { (USD / GJ) }\end{array}$ & $\begin{array}{c}\text { Price } \\
\text { (USD / tonne) }\end{array}$ & Cost structure \\
\hline Forest residues & $30 \%-40 \%$ & 11.5 & $1.30-2.61$ & $15-30$ & $\begin{array}{l}\text { Collecting, harvesting, } \\
\text { chipping, loading, } \\
\text { transportation and } \\
\text { unloading. Stumpage } \\
\text { fee and return for profit } \\
\text { and risk. }\end{array}$ \\
\hline Wood waste $^{1}$ & $5 \%-15 \%$ & 19.9 & $0.50-2.51$ & $10-50$ & $\begin{array}{l}\text { Cost can vary from } \\
\text { zero, where there } \\
\text { would otherwise be } \\
\text { disposal costs, to quite } \\
\text { high, where there is an } \\
\text { established market for } \\
\text { their use in the region. }\end{array}$ \\
\hline Agricultural residues ${ }^{2}$ & $20 \%-35 \%$ & $11.35-11.55$ & $1.73-4.33$ & $20-50$ & $\begin{array}{l}\text { Collecting, premium } \\
\text { paid to farmers, } \\
\text { transportation. }\end{array}$ \\
\hline Energy crops ${ }^{3}$ & $10 \%-30 \%$ & $14.25-18.25$ & $4.51-6.94$ & $39-60$ & Not disclosed. \\
\hline Landfill gas & - & $18.6-29.8^{4}$ & $0.94-2.84$ & $0.017-0.051^{4}$ & $\begin{array}{l}\text { Gas collection and } \\
\text { flare. }\end{array}$ \\
\hline
\end{tabular}

${ }^{1}$ Sawmills, pulp and paper companies (bark, chip, sander dust, sawdust). Moisture content is often low because they have already been through a manufacturing process. In cases where disposal is required, prices can be zero as the avoided costs of disposal can make it worthwhile to find a productive use for the feedstock.

${ }^{2}$ Corn stover and straw.

${ }^{3}$ Poplar, willow and switchgrass. disadvantages of energy crops are higher overall cost than many fossil fuels, higher-value alternative land uses that further drive up costs.

${ }^{4}$ For landfill gas the heat value and price is in $\mathrm{MJ} / \mathrm{m}^{3} \mathrm{USD} / \mathrm{m}^{3}$. 


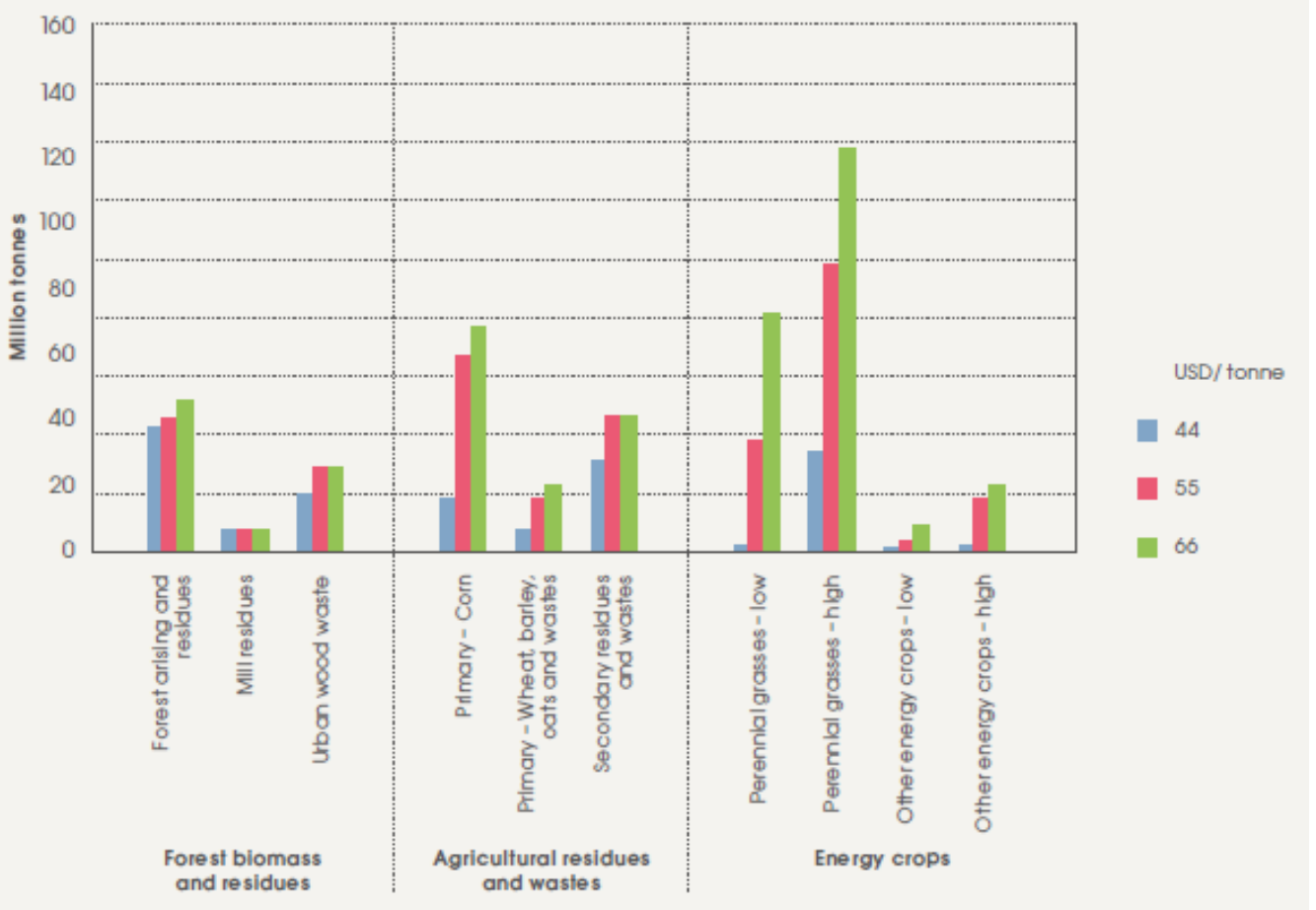

Noter "Secondary residues and wastes" include rice field and husk residues, cotfon field residues and gin frash, sugarcane residue, orchard and vineyard prunings, wheat dust and animal manure. "Other energy crops" include woody crops and annual energy crops Energy crop dafa are for 2017, all other dafa for $20 \mathrm{R}$.

Figure 3. Renewable power generation costs indicators and boundaries. (Source: IRENA, 2012 based on US DOE, 2011)

In Europe, an analysis of four biomass sources and supply chains, made by the European Climate Foundation in 2010, identified feedstock costs in between $4.7 €$ and $7.4 € / \mathrm{GJ}$ for European sourced wood chips. Local agricultural residues were estimated to cost $4.3 €$ to 5.4 $€ /$ GJ. Imported pellets from North America are competitive with European wood chips if they are transported from Scandinavia to continental Europe. These are representative examples, and there will be significant variation in actual feedstock costs, depending on the actual project details.

Table 4. Biomass feedstock costs including transport for use in Europe. (Source: European Climate Foundation, 2010)

\begin{tabular}{|c|c|c|c|c|c|c|c|}
\hline & \multicolumn{2}{|c|}{ Feedstock } & \multicolumn{2}{|c|}{ Transport } & \multicolumn{2}{|c|}{ Total costs } \\
\hline & & $\epsilon / G J$ & $\epsilon /$ tonne & $\epsilon / G J$ & $\epsilon /$ tonne & $\epsilon / G J$ & $\epsilon /$ tonne \\
\hline \multicolumn{2}{|c|}{$\begin{array}{l}\text { Woodchips from local energy } \\
\text { crops }\end{array}$} & $4.7-7.4$ & $54-85$ & - & - & $4.7-7.4$ & $54-85$ \\
\hline \multicolumn{2}{|c|}{$\begin{array}{l}\text { Woodchips from } \\
\text { Scandinavian forest residues } \\
\text { to continental Europe }\end{array}$} & $5.1-6.1$ & $58-70$ & $2.7-3.1$ & $30-34$ & $7.7-9.1$ & $89-104$ \\
\hline \multicolumn{2}{|c|}{ Local agricultural residues } & $4.3-5.4$ & $50-61$ & - & - & $4.3-5.4$ & $50-61$ \\
\hline \multirow{3}{*}{$\begin{array}{l}\text { Imported } \\
\text { pellets (from } \\
\text { U.S. to } \\
\text { continental } \\
\text { Europe) }\end{array}$} & Feedstock & $2.7-3.3$ & $45-57$ & - & - & $2.7-3.3$ & $45-57$ \\
\hline & Pelletizing & $2.7-3.1$ & $45-50$ & - & - & $2.7-3.1$ & $45-50$ \\
\hline & Total & $5.4-6.4$ & $90-109$ & $3.1-3.4$ & $50-57$ & $8.4-9.7$ & $141-164$ \\
\hline
\end{tabular}

"The European Commission support for the production of this publication does not constitute an endorsement of the contents which reflects the views only of the authors, and the Commission cannot be held responsible for any use which may be made of the information contained therein." 


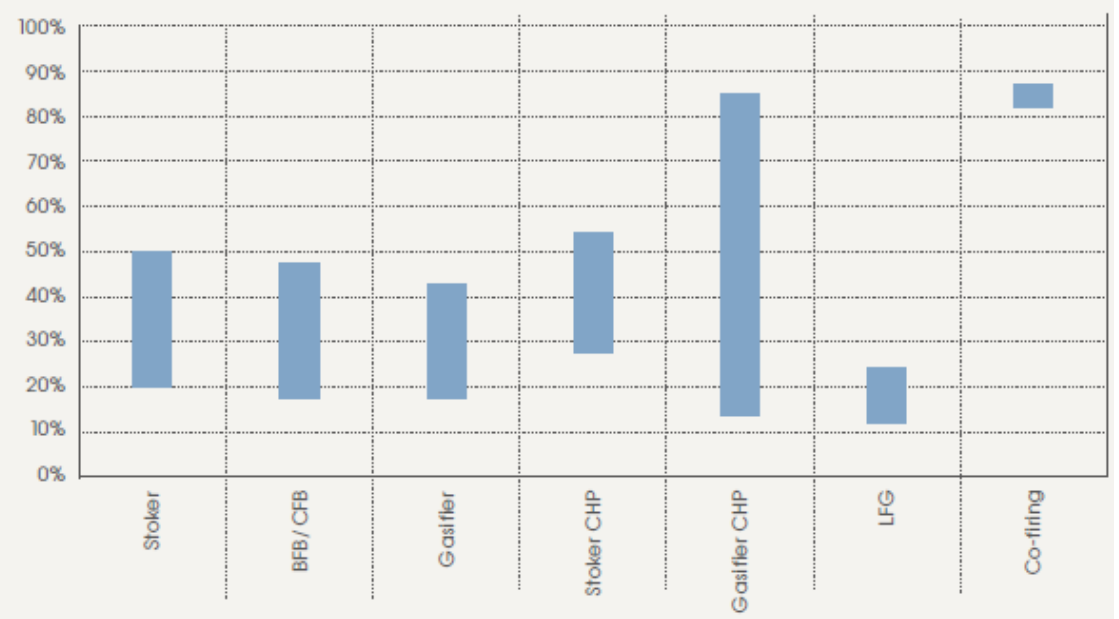

Figure 4. The LCOE framework for biomass power generation. (Source: IRENA, 2012)

Figure 4 presents the impact of the high and low ranges for the feedstock costs on their share of the LCOE of different biomass technologies. Excluding co-firing, which is a special case, feedstock costs typically account for $20 \%$ to $50 \%$ of the LCOE of power generation. The range is significantly wider for gasifier-based CHP projects, where the feedstock cost can account for as little as $14 \%$ of the LCOE but up to $85 \%$ in the case of using imported wood chips.

During the early springs of 2010 and 2011 respectively, prices of different assortments of wood fuels in the countries participating in EUBIONET III $^{1}$ were collected from the respective partners in two rounds. The instructions for the partners in the first round stated that ideally, time series of prices stretching from the second half of 2006 - the time of the last price collections of the EUBIONET II project - to early 2010, and in the second round for the year 2010 were to be collected.

Figures 5-9 show the prices of different raw materials between 2006-2011 (in case of Figure 5, between 2006-2010) in the European countries. In order to make comparison, the prices on the industrial market and on the residential market both are displayed.

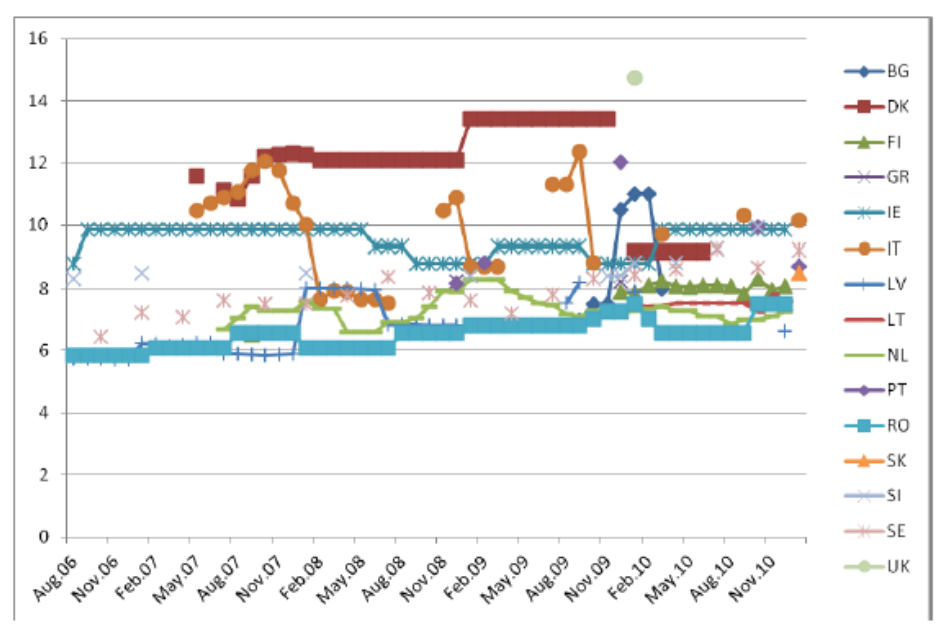

Figure 5. Wood pellets (industrial market), €/GJ. (Source: Vinterbäck - Porsö 2011)

\footnotetext{
${ }^{1}$ For more information visit http://www.eubionet.net/
}

"The European Commission support for the production of this publication does not constitute an endorsement of the contents which reflects the views only of the authors, and the Commission cannot be held responsible for any use which may be made of the information contained therein." 


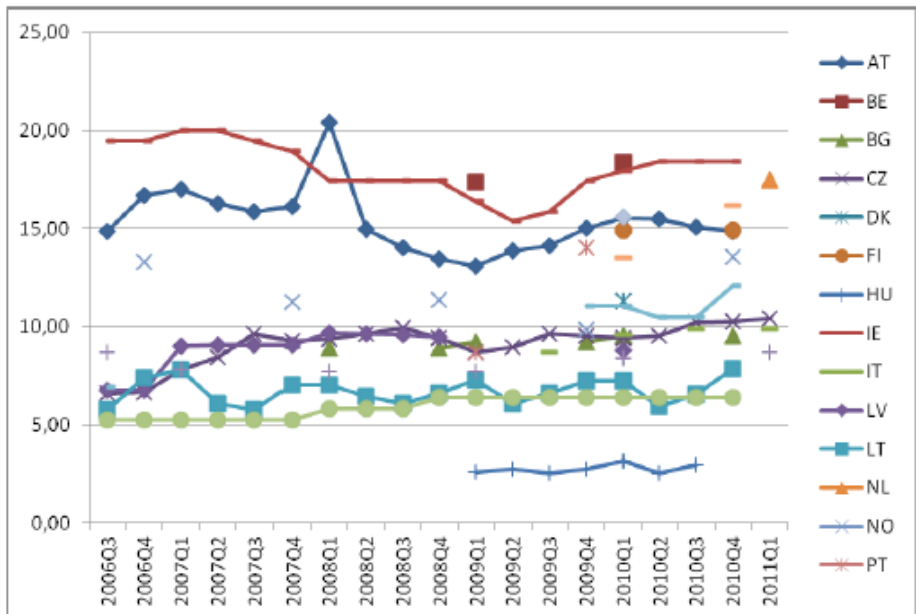

Figure 6. Wood briquettes (residential market), €/GJ. (Source: Vinterbäck - Porsö 2011)

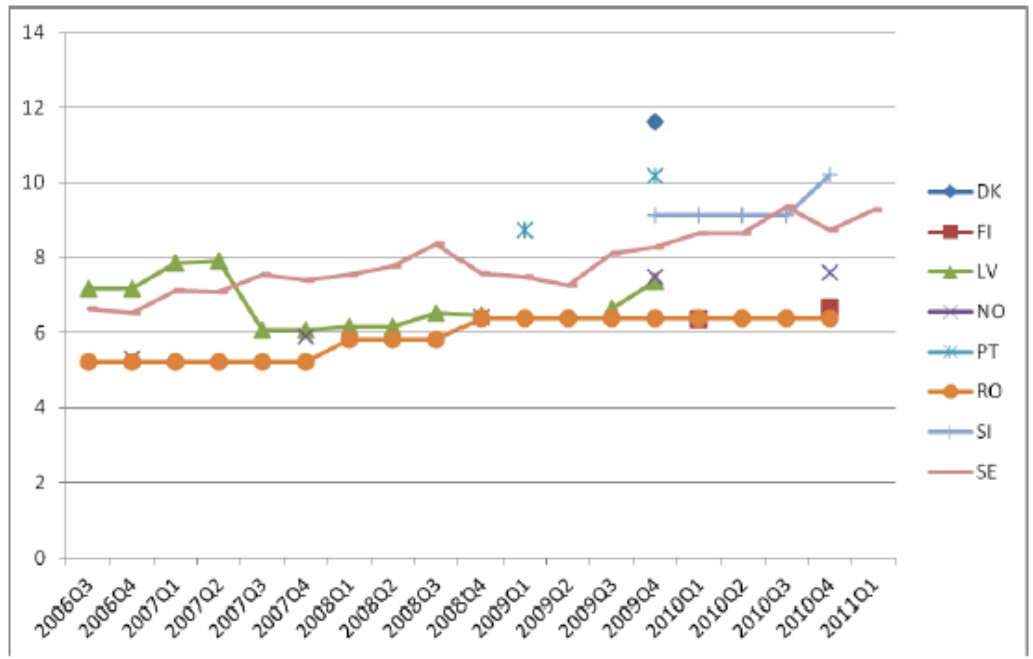

Figure 7. Wood briquettes (industrial market), €/GJ. (Source: Vinterbäck - Porsö 2011)

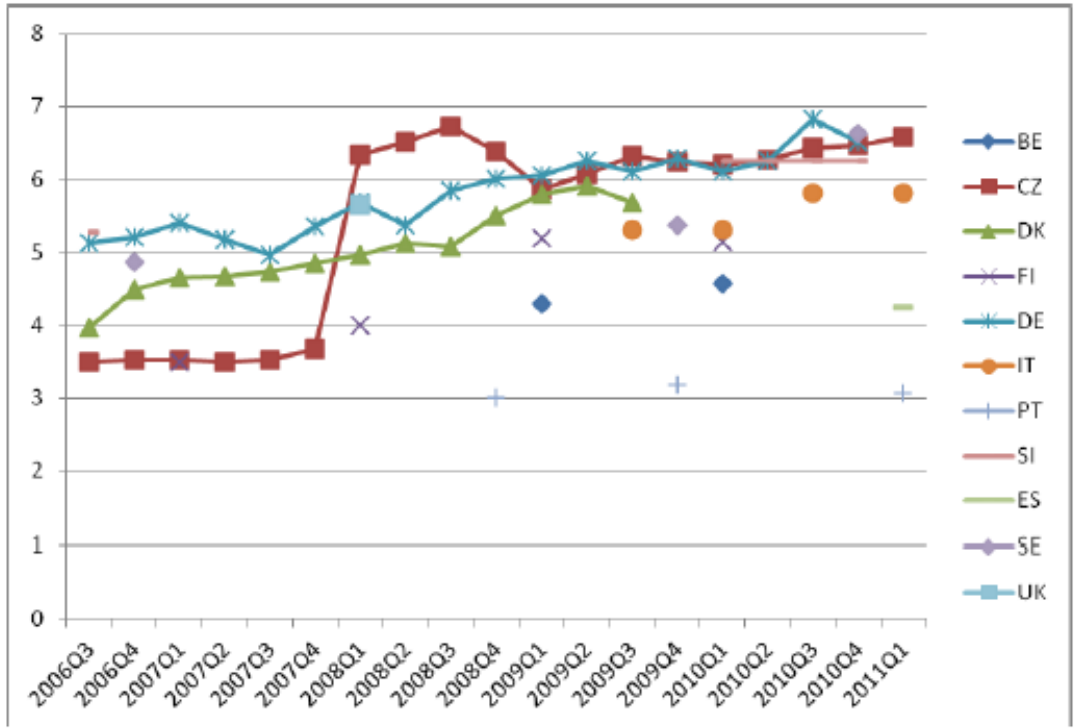

Figure 8. Wood chips (residential market), €/GJ. (Source: Vinterbäck - Porsö 2011) 


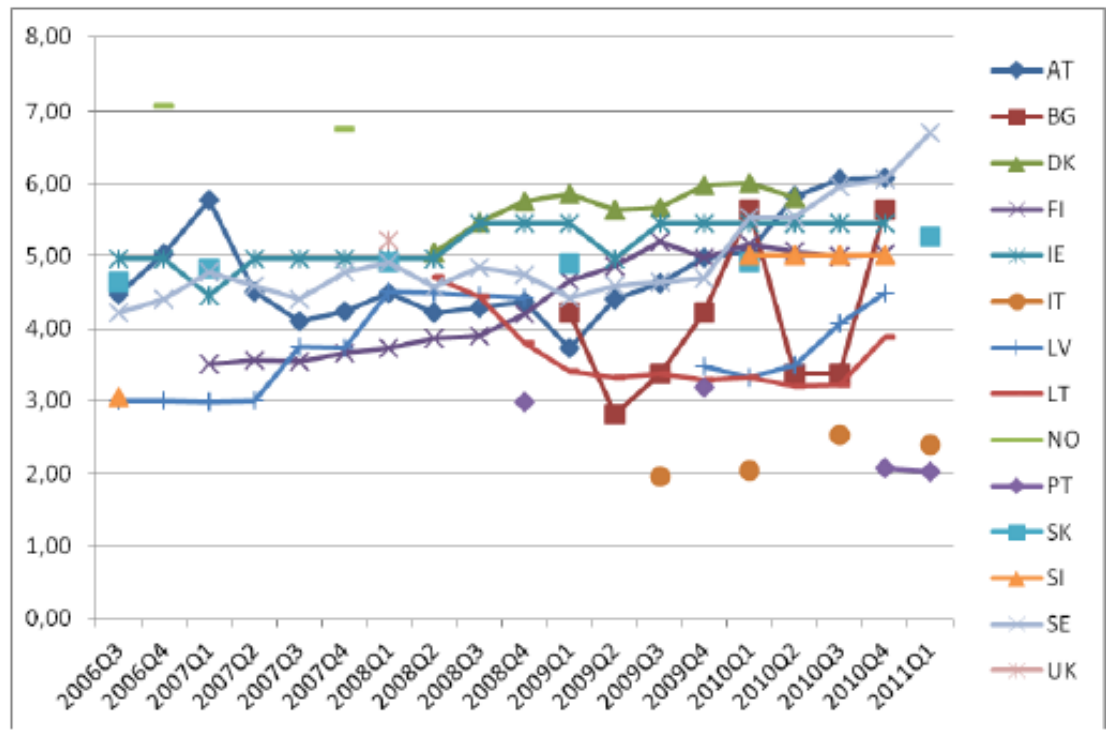

Figure 9. Wood chips (industrial market), €/GJ. (Source: Vinterbäck - Porsö 2011)

\section{$\underline{\text { Technology costs }}$}

The cost and efficiency of biomass power generation equipment varies significantly by technology. Equipment costs for an individual technology type can also vary, depending on the region but also depending on the nature of the feedstock and how much feedstock preparation and handling is done onsite. Table 5 presents the equipment costs for representative technologies by size.

Table 5. Estimated costs for biomass power generation technologies by study (2010, costs in $\mathrm{USD}^{2} / \mathrm{kW}$ ). (Source: IRENA, 2012)

\begin{tabular}{|l|l|l|l|l|}
\hline & \multicolumn{1}{|c|}{ O`Connor, 2011 } & $\begin{array}{c}\text { Mott MacDonald, } \\
\mathbf{2 0 1 1}\end{array}$ & $\begin{array}{c}\text { EPA, 2007 } \\
\text { and EIA, 2010 }\end{array}$ & Obernberger, 2008 \\
\hline Stoker boiler & $2,600-3,000$ & $1,980-2,590$ & $1,390-1,600$ & 2,080 \\
\hline Stoker CHP & $2,500-4,000$ & & $3,320-5,080^{*}$ & 3,019 \\
\hline CFB & $2,600-3,000$ & 1,440 & $1,750-1,960$ & \\
\hline CFB CHP & & & $4,260-15,500$ & \\
\hline BFB & & 2,540 & 3,860 & \\
\hline Co-firing & $100-600$ & & & \\
\hline $\begin{array}{l}\text { 100\% biomass } \\
\text { repowering }\end{array}$ & $900-1,500$ & & & \\
\hline MSW & $5,000-6,000$ & & 1,730 & $4,321-5,074$ \\
\hline $\begin{array}{l}\text { Fixed bed gasifier } \\
\text { ICE }\end{array}$ & & 4,150 & & \\
\hline $\begin{array}{l}\text { Fixed bed gasifier } \\
\text { GT }\end{array}$ & $3,000-3,500$ & & $2,470-4,610$ & \\
\hline $\begin{array}{l}\text { Fluidised gasifier } \\
\text { GT }\end{array}$ & & & $2,200-7,894$ & \\
\hline BIGCC & $3,500-4,300$ & & & \\
\hline Digester ICE & $1,650-1,850$ & $2,840-3,665$ & & \\
\hline Digester GT & $1,850-2,300$ & & 1,804 & \\
\hline Landfill gas ICE & $1,350-1,500$ & & & \\
\hline
\end{tabular}

Note: $*=$ CHP back pressure steam turbine. ICE $=$ internal combustion engine. GT = gas turbine. MSW = municipal solid waste.

\footnotetext{
${ }^{2}$ The conversion rate in 2010 from USD to EUR was 0.785 .
}

"The European Commission support for the production of this publication does not constitute an endorsement of the contents which reflects the views only of the authors, and the Commission cannot be held responsible for any use which may be made of the information contained therein." 
Costs of a biomass combustion plant

Concerning the fact that biomass combustion can be the most widely used technology, a more detailed economic analysis of biomass combustion plants is covered in this section. Biomass combustion plants are complex systems with numerous components. In order to ensure a sustainable and economic operation of such plants, professional dimensioning and engineering are essential.

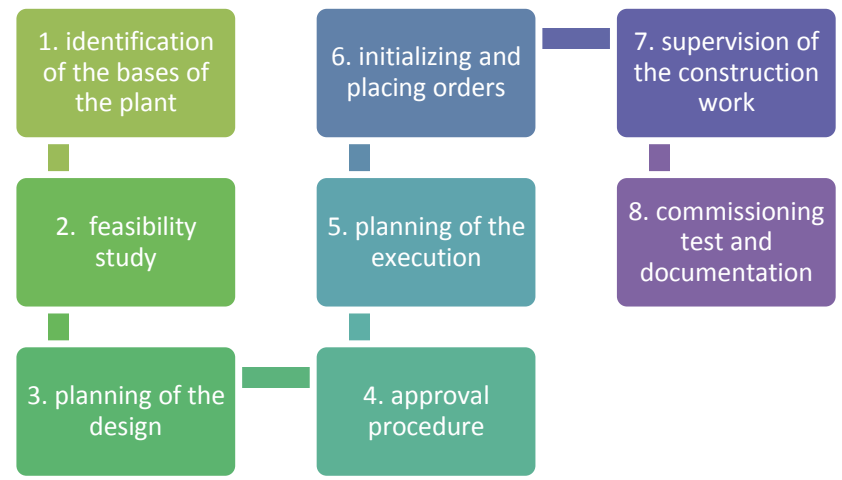

Figure 10. The process of engineering. (Source: van Loo - Koppejan, 2008)

In Austria, which is one of the leading countries regarding biomass-based energy production (see Chapter 4), technical and economic standards have been defined for biomass district heating plants in order to secure an economically reasonable investment. Keeping to these standards is a requirement for new biomass district heating or CHP projects in Austria; otherwise, no investment subsidies are granted. So, it can be useful to apply these standards in any other country. Some of the main parameters and calculations defined in the standards are:

$$
\begin{gathered}
\text { Simultaneity factor }[\%]=\frac{\text { effective peak heat load }- \text { district heat work }}{\sum \text { consumer nominal connection capacities }} \\
\text { Boiler full load operating hours }[\mathrm{h} / \mathrm{a}]=\frac{\text { boiler heat produced per year }}{\text { boiler nominal capacity }} \\
\begin{array}{r}
\text { Annual utilization rate of biomass combustion plant }[\%] \\
=\frac{\text { boiler heat produced per year }}{\text { fuel heat input }(\mathrm{NCV}) \text { per year }} \times 100 \%
\end{array} \\
\begin{array}{c}
\text { Network utilization rate }[\mathrm{kWh} / \mathrm{m}]=\frac{\text { heat sold per year }[\mathrm{kWh}]}{\text { length of pipe network }[\mathrm{m}]} \\
=\frac{\text { heat sold to final consumers per year }}{\text { heat output from heating plant per year }} \times 100 \% \\
\text { Specific investment }(\text { boiler })[\text { Euro } / \mathrm{kW}] \\
=\frac{\text { Investment cost of total system }[\text { Euro }]}{\text { nominal capacity of biomass boiler }[\mathrm{kW}]}
\end{array}
\end{gathered}
$$




\section{Heat generation costs [Euro/MWh]$$
=\frac{(\text { annualized capital costs }+ \text { other payments)per year }[\text { Euro }]}{\text { heat sold per year }[M W h]}
$$

The nominal thermal capacity of a biomass district heating or heat-controlled CHP plant is determined by the energy demand (heat, electricity) and has to allow for future developments. Therefore, as a first step, a detailed and precise survey of capacity and heat requirements in the supply area is necessary. Moreover, the simultaneity of heat demand of the district heating clients, described by the simultaneity factor, has to be taken into consideration. This factor depends on the number and type of consumers and fluctuates between 0.5 (large district heating networks) and 1 (micro-networks).

In most cases, the energy demand is not constant over the year. In fact, the heat load in district heating networks especially varies during the year, reaching a maximum in winter and a minimum in summer. Therefore, on the basis of the results of the survey of capacity and heat requirements, the annual heat output line has to be calculated. In boiler planning, a distinction must be done between base load and peak load for economic reasons. Base load is covered by one or more biomass boilers, while peak load boilers are usually run for economic reasons on fossil energy or liquid biofuels. The installation of heat accumulators can also contribute to peak load coverage. This distinction between base load and peak load is necessary to achieve a high number of full-load operating hours of the biomass boiler and to decrease the total heat generation costs. The correct determination of the boiler sizes depends on the capital costs of the combustion unit as well as on the operating costs.

Table 6. Comparison of specific investment and fuel costs for biomass and fuel oil-fired combustion systems. (Source: van Loo - Koppejan, 2008)

\begin{tabular}{|l|l|l|}
\hline \multicolumn{1}{|c|}{ Combustion system } & \multicolumn{1}{c|}{ Specific investment costs } & \multicolumn{1}{c|}{ Fuel costs } \\
\hline Biomass & high (about $€ 160 / \mathrm{kW})^{1}$ & $\begin{array}{l}\text { low }(\text { about } € 15-25 / \\
\left.\mathrm{MWh}_{\mathrm{NCV}}\right)\end{array}$ \\
\hline Fuel oil & low (about $€ 20 / \mathrm{kW})^{2}$ & $\begin{array}{l}\text { high }(\text { about } € 55-65 / \\
\left.\mathrm{MWh}_{\mathrm{NCV}}\right)\end{array}$ \\
\hline
\end{tabular}

${ }^{1} 5 \mathrm{MW}_{\text {th }}$ biomass combustion unit (fuel feeding, furnace, boiler, multicyclone, ESP, stack)

${ }^{2} 5 \mathrm{MW}_{\text {th }}$ fuel oil boiler with oil tank, burner and stack; specific investment costs related to nominal boiler capacity

The annual utilization rate of the biomass system (biomass boiler + heat recovery) in the overall plant should be at least 85 per cent. Therefore, the installation of a heat recovery system (e.g. economizer or flue gas condensation unit) is recommended.

For biomass CHP plants, mainly heat-controlled operation is recommended. The annual utilization rate should be at least 75 per cent. Therefore, biomass CHP applications should only be realized on sites where the heat produced can be utilized in a reasonable way. This guideline is also valid for co-firing plants.

The fuel storage unit should be small and should be designed for just-in-time operation (capacity of the biomass storage unit less than 10 per cent of annual fuel consumption). Care should be taken to arrange for appropriate fuel supply contracts, organized fuel purchase and regional coordination. If appropriate long-term fuel supply contracts cannot be established, the fuel storage should be designed for a higher storage capacity, depending on the regional framework conditions. 
The costs of the buildings should be less than $€ 150$ per $\mathrm{m}^{3}$ converted space; the costs of the storage unit should be less than $€ 80$ per $\mathrm{m}^{3}$ of converted space.

The costs of the heat distribution network account for 35-55 per cent of the total investment costs of complete district heating plants. Thus, it is important to calculate the network correctly in order to achieve high rates of utilization and to concentrate on a small and efficient network of pipes. For biomass district heating networks, the network heat utilization rate should exceed $800 \mathrm{kWh} / \mathrm{m}$; the targeted value is $1200 \mathrm{kWh} / \mathrm{m}$. Moreover, a maximum temperature spread between feed and return should be achieved. The targeted value for biomass district heating plants is $40^{\circ} \mathrm{C}$ or higher. The annual utilization rate of district heating networks should exceed 75 per cent.

Regarding heat generation, four types of costs can be distinguished:

1. capital costs (depreciation, interest costs),

2. consumption-based costs (fuel, materials like lubricants)

3. operation-based costs (personnel costs, costs for maintenance)

4. other costs (administration, insurance)

In comparison to energy systems run on fossil fuels, investment costs for biomass boilers including fuel supply systems and flue gas cleaning are high. Typical values for total investment costs for biomass combustion plants in Austria and Denmark are shown in Figure 11. Therefore, optimal plant utilization is necessary to decrease heat generation costs. Figure 12 illustrates the influence of the boiler full-load operating hours on the capital costs of biomass combustion units. In order to take advantage of the decline of marginal unit costs, the boiler full-load operating hours of the biomass combustion unit should exceed 4000 hours per year. For biomass CHP plants in heat-controlled operation, the target is 5000 boiler full-load operating hours or more.

It should be noted that the principles stated in this section are not only valid for small and medium-scale biomass heating and CHP plants, but also for large biomass CHP and co-firing units. However, with increasing plant size the importance of the investment costs decreases (the economy-of-scale effect already indicated in Figure 11 continues for larger plant sizes) and the relevance of the fuel costs on the energy generation costs increases.

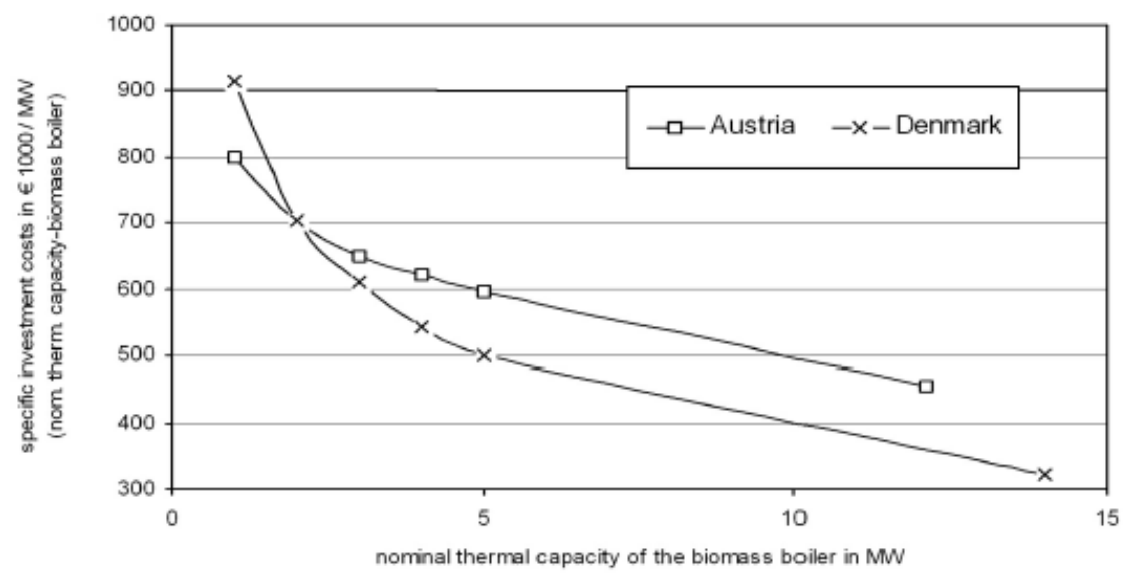

Figure 11. Specific investment costs for biomass combustion plants in Austria and Denmark as a function of biomass boiler size. (Source: van Loo - Koppejan, 2008) 


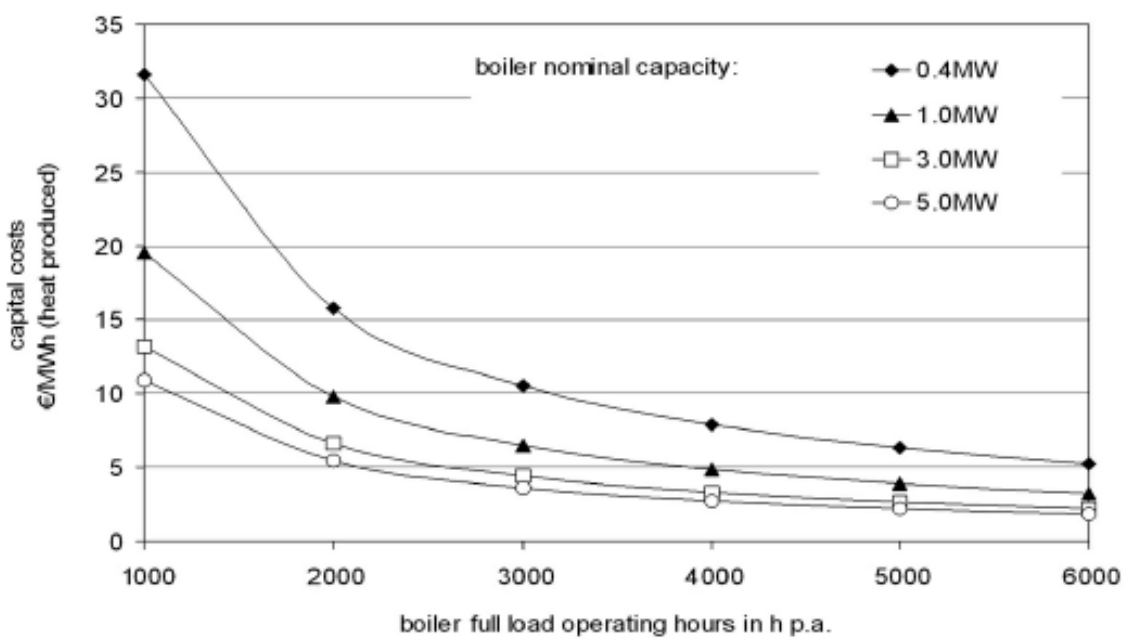

Figure 12. Specific capital costs for biomass combustion systems as a function of boiler capacity and boiler utilization. (Source: van Loo - Koppejan, 2008)

\section{Spatial planning}

The prices of spatial planning depend on a number of factors. They vary from country to country, from region to region, from subject to subject. Therefore, it is almost impossible to give exact numbers about the prices of spatial planning in connection with the establishment of biomass-based plants.

As stated by United Nations Economic Commission for Europe, when well established in government, spatial planning is an activity that can effectively pay for itself. The value of responsible investment in infrastructure and development far outweighs the costs of the planning system. Effective spatial planning integrates the decisions and activities of many actors that are anticipated to add value to the development process. It will help to create value in land and property and further protect that value and help to ensure good returns for investors. Coordination of investment through a territory-based strategy can direct public investment so as to avoid wasteful expenditure. Spatial planning should help to reduce environmental costs and other externalities such as traffic congestion. In some countries, spatial planning is seen as an important contributor to the health and well-being of citizens, thus reducing costs in other sectors. Above all, in the long term, effective spatial planning will reduce the costs of uncoordinated, environmentally damaging and fragmented development patterns, by adding value through the synergy of investment.

An effective spatial planning system can help provide necessary infrastructure through impact fees and agreements made with developers. It may also help to provide additional community facilities and other services through recouping part of the development value of land and property. More directly, the costs of the administration of spatial planning can be offset by charging fees to those who seek approval for development. Many countries already have such fee systems in place. The information collected in the spatial planning process will be of value to the development industry. Some information will be made freely available through planmaking and regulation process, but it is commonplace for planning authorities to charge for the provision of special information. For example, this might include more detailed assessments of the economic performance of land and property. In some cases, planning authorities charge for the provision of their planning documents, though this is usually only to cover administrative costs. Relevant summary information should always be readily available to the community. 
Since many biomass-related projects are implemented with the support of the financial funds and sources of the European Union, a possible approach can be, if one makes calculations with the financial limit values and rates defined by the various tenders ${ }^{3}$.

Table 7. The scope and rate of eligible expenditures in the previous and the current programming period.

\begin{tabular}{|c|c|c|}
\hline \multirow{2}{*}{ Cost type } & \multicolumn{2}{|c|}{ Rate (\%) } \\
\hline & $2007-2013$ & 2014-2020 \\
\hline Direct costs & $10.5-22 \%$ & $7 \%$ \\
\hline Purchasing property (land, buildings, etc.) & $10 \%$ & $2 \%$ \\
\hline Site preparation & $0-6 \%$ & $2 \%$ \\
\hline $\begin{array}{l}\text { Project preparation, planning (environmental impact } \\
\text { assessment, sustainability study, feasibility study, } \\
\text { construction and engineering business plans) }\end{array}$ & $0.5-6 \%$ & $5 \%$ \\
\hline Indirect costs & $6-23.5 \%$ & $5.5 \%$ \\
\hline Project management & $2-12 \%$ & $2.5 \%$ \\
\hline Conducting public procurement procedures & $1-1.5 \%$ & $1 \%$ \\
\hline Technical inspection services & $2-7 \%$ & $1 \%$ \\
\hline Audit & $0.5-1 \%$ & $0.5 \%$ \\
\hline Information and publicity & $0.5-2 \%$ & $0.5 \%$ \\
\hline Total & $16.5-45.5 \%$ & $12.5 \%$ \\
\hline
\end{tabular}

\section{References}

Breeze, P. (2004). The Future of Global Biomass Power Generation: The technology, economics and impact of biomass power generation. Business Insights.

Caputo, A. C.; Palumbo, M.; Plagagge, M., \& Scacchia, F. (2005). Economics of biomass energy utilization in combustion and gasification plants: effects of logistic variables. Biomass and Bioenergy, 28, 35-51.

EUROSTAT (2015). Energy price statistics. EUROSTAT. Retrieved 2/02/2016, from http://ec.europa.eu/eurostat/statistics-explained/index.php/Energy_price_statistics

IRENA (2012). Biomass for Power Generation. IRENA Working Paper: Renewable Energy Technologies: Cost Analysis Series. Retrieved 2/02/2016, from https://www.irena.org/DocumentDownloads/Publications/RE_Technologies_Cost_AnalysisBIOMASS.pdf

Jansen, R. A. (2012). Second Generation Biofuels and Biomass: Essential Guide for Investors, Scientists and Decision Makers. Wiley.

Matovic, M. D. (ed.) (2013). Biomass Now - Cultivation and Utilization. InTech.

Matovic, M. D. (ed.) (2013). Biomass Now - Sustainable Growth and Use. InTech.

\footnotetext{
${ }^{3}$ See Commission Regulation (EU) No 651/2014 of 17 June 2014 declaring certain categories of aid compatible with the internal market in application of Articles 107 and 108 of the Treaty Text with EEA relevance.

"The European Commission support for the production of this publication does not constitute an endorsement of the contents which reflects the views only of the authors, and the Commission cannot be held responsible for any use which may be made of the information contained therein."
} 
National Research Council (2011). Renewable Fuel Standard: Potential Economic and Environmental Effects of U.S. Biofuel Policy. Committee on Economic and Environmental Impacts of Increasing Biofuels Production; National Research Council.

Riva, G. et. al. (2012). Handbook on Renewable Energy Sources. ENER SUPPLY. Retrieved 2/02/2016, from http://www.ener-supply.eu/downloads/ENER handbook_en.pdf

UNECE (2008). Spatial planning: Key Instrument for Development and Effective Governance with Special Reference to Countries in Transition. United Nations Economic Commission for Europe. $\quad$ Retrieved 2/02/2016, from http://www.unece.org/fileadmin/DAM/hlm/documents/Publications/spatial_planning.e.pdf

van Loo, S., \& Koppejan, J. (eds.) (2008). The Handbook of Biomass Combustion and Cofiring. Earthscan.

Vinterbäck, J., \& Porsö, C. (2011). Solutions for biomass fuel market barriers and raw material availability: Wood fuel price statistics in Europe. EUBIONET III. Retrieved $2 / 02 / 2016$, from http://www.eubionet.net/GetItem.asp?item=digistorefile;320376;1540\&params=open;gallery

Wichtmann, W., \& Wichmann, S. (2011). Environmental, Social and Economic Aspects of a Sustainable Biomass Production. Journal of Sustainable Energy \& Environment Special Issue, 77-81. 


\title{
MODULE 3: BIOMASS
}

CHAPTER 2. Economic aspects.

Subchapter 2.2.: Other costs (employment, management, maintenance, etc.).

\author{
Dr. Zsolt Radics \\ Geolin Co., Hungary
}

Summary: The subchapter suggests the fixed and variable operating and maintenance costs for biomass power and estimates the employments costs by position and country.

\section{Operation and maintenance}

As it was introduced in the previous modules, operation and maintenance (O\&M) refer to the fixed and variable costs associated, in this case, with the operation of biomass-fired power generation plants. Fixed O\&M costs can be expressed as a percentage of capital costs. For biomass power plants, they typically range from $1 \%$ to $6 \%$ of the initial CAPEX ${ }^{1}$ per year (Table 1).

Table 1. Fixed and variable operating and maintenance $\operatorname{costs}^{2}$ for biomass power. (Source: IRENA 2012)

\begin{tabular}{|c|c|c|}
\hline Technology & $\begin{array}{c}\text { Fixed O\&M (\% of installed } \\
\text { cost) }\end{array}$ & Variable O\&M (€ / MWh) \\
\hline Stokers / BFB / CFC boilers & $3-6$ & $3.4-4.2$ \\
\hline Gasifier & $3-6$ & 3.3 \\
\hline AD systems & $2.1-7$ & 4.2 \\
\hline LFG & $11-20$ & n.a. \\
\hline
\end{tabular}

Fixed O\&M costs consist of labour, scheduled maintenance, routine component/equipment replacement (for boilers, gasifiers, feedstock handling equipment, etc.), insurance, etc. The

\footnotetext{
${ }^{1}$ Capital expenditure (CAPEX or CapEx) are funds used by a company to acquire or upgrade physical assets such as property, industrial buildings or equipment. It is often used to undertake new projects or investments by the firm. This type of outlay is also made by companies to maintain or increase the scope of their operations. These expenditures can include everything from repairing a roof to building, to purchasing a piece of an equipment, or building a brand new factory.

2 Operating costs are expenses associated with the maintenance and administration of a business on a day-today basis. The operating cost is a component of operating income and is usually reflected on a company's income statement. While operating costs generally do not include capital outlays, they can include many components of operating a business.

Fixed costs can help in achieving economies of scale, as when many of a company's costs are fixed the company can make more profit per unit as it produces more units. In this system, fixed costs are spread out over the number of units produced, making production more efficient as production increases by reducing the average per-unit cost of production. Economies of scale can allow large companies to sell the same goods as smaller companies for lower prices.

Variable costs, like the name implies, are comprised of costs that may vary. Unlike fixed costs, variable costs will increase as production increases and decrease as production decreases. Examples of variable costs include raw material costs, payroll and the cost of electricity and other utilities.
}

"The European Commission support for the production of this publication does not constitute an endorsement of the contents which reflects the views only of the authors, and the Commission cannot be held responsible for any use which may be made of the information contained therein." 
larger the plant, the lower the specific (per $\mathrm{kW}$ ) fixed O\&M costs, because of the impact of economies of scale, particularly for the labour required.

Variable O\&M costs depend on the output of the system and are usually expressed as a value per unit of output $(€ / \mathrm{kWh})$. They include non-biomass fuels costs, ash disposal, unplanned maintenance, equipment replacement and incremental servicing costs. The data available will often combine fixed and variable O\&M costs into one number so a breakdown between fixed and variable O\&M costs is often not available.

Fixed O\&M costs range from $2 \%$ of installed costs per year to $7 \%$ for most biomass technologies, with variable O\&M costs of around $0.004 € / \mathrm{kWh}$. Landfill gas systems have much higher fixed O\&M costs, which can be between $10 \%$ and $20 \%$ of the initial capital costs per year.

Care should be taken in comparing the O\&M costs of gasifiers with other bioenergy power generation technologies since gasifiers have less commercial experience and are not as mature as the other solutions.

Operations and maintenance (O\&M) costs can make a significant contribution to the levelized cost of electricity (LCOE) and typically account for between 9\% and 20\% of the LCOE for biomass power plants. It can be lower than this in the case co-firing and in greater plants with extensive fuel preparation, handling and conversion needs.

\section{$\underline{\text { Employment }}$}

Employment costs of biomass-based power plants depend on the technology (complexity), the size/performance of the plant (number of employees needed), and also on the given country.

First, the personnel needs of the power plant have to be defined. In case of a woody biomassbased electrical power plant, the personnel needs change according to Table 2.

Table 2. Personnel needs of a power plant by the performance. (Source: Missouri Department of Natural Resources, 2012)

\begin{tabular}{|l|c|c|c|c|}
\hline \multicolumn{1}{|c|}{ Personnel needs } & 4 MW & 8 MW & 15 MW & 20 MW \\
\hline Woody Biomass Skill Trades (estimated) & \multicolumn{2}{l|}{} \\
\hline Feller (4 man crew per 2 MW) & 8 & 16 & 30 & 40 \\
\hline Skid Operators & 3 & 6 & 10 & 12 \\
\hline Chipper Operators & 3 & 6 & 10 & 12 \\
\hline Loader Operators & 3 & 6 & 10 & 12 \\
\hline Truck Drivers & 3 & 6 & 10 & 12 \\
\hline Supervisor/Forester & 2 & 2 & 2 & 4 \\
\hline Management & 3 & 4 & 4 & 4 \\
\hline Accounting/Finance & 2 & 2 & 2 & 2 \\
\hline Electrical Power Plant Trades & \multicolumn{5}{|l|}{} \\
\hline Boiler Operators & 8 & 8 & 8 & 8 \\
\hline Electricians & 4 & 4 & 4 & 4 \\
\hline Labourers & 4 & 4 & 4 & 4 \\
\hline Equipment Operators & 6 & 6 & 6 & 6 \\
\hline Supervisors & 4 & 4 & 4 & 4 \\
\hline Management & 2 & 2 & 2 & 2 \\
\hline Accounting/Finance & 2 & 2 & 2 & 2 \\
\hline
\end{tabular}


78

108

Table 3. Some examples of salaries per month in the sector. (Source: Collected by the author based on open positions)

\begin{tabular}{|l|c|c|c|}
\hline \multicolumn{1}{|c|}{ Position } & Country & in local currency & in $€$ \\
\hline $\begin{array}{l}\text { Biomass Commissioning } \\
\text { \& Service Engineer }\end{array}$ & United Kingdom & $£ 2,700-3,000$ & $€ 3,500-3,900$ \\
\hline $\begin{array}{l}\text { Engineering Operations } \\
\text { Manager }\end{array}$ & United Kingdom & $£ 3,800-4,200$ & $€ 4,950-5,450$ \\
\hline $\begin{array}{l}\text { Electrical Maintenance } \\
\text { Technician }\end{array}$ & United Kingdom & $£ 2,000-2,300$ & $€ 2,600-3,000$ \\
\hline $\begin{array}{l}\text { Senior Sustainability } \\
\text { Consultant }\end{array}$ & United Kingdom & $£ 2,500-3,300$ & $€ 3,250-4,300$ \\
\hline $\begin{array}{l}\text { Biomass Field Service } \\
\text { Engineer }\end{array}$ & United Kingdom & $£ 2,300-3,000$ & $€ 3,000-3,900$ \\
\hline $\begin{array}{l}\text { Biomass Engineer - } \\
\text { Renewables }\end{array}$ & United Kingdom & $£ 2,500-2,800$ & $€ 3,250-3,650$ \\
\hline CHP Engineer & United Kingdom & $£ 2,700-3,000$ & $€ 3,500-3,900$ \\
\hline $\begin{array}{l}\text { Heating Engineer } \\
\text { Renewable energy }\end{array}$ & United Kingdom & $£ 2,100-2,500$ & $€ 2,700-3,250$ \\
\hline $\begin{array}{l}\text { Anaerobic Digestion } \\
\text { Process Specialist }\end{array}$ & United Kingdom & $£ 2,500-3,300$ & $€ 3,250-4,300$ \\
\hline Biomass Plant Technician & United States & $\$ 3,100-6,000$ & $€ 4,000-7,800$ \\
\hline
\end{tabular}

Table 4. Average salaries in the European Union. (Source: https://www.reinisfischer.com/average-salary-european-union-2015) 


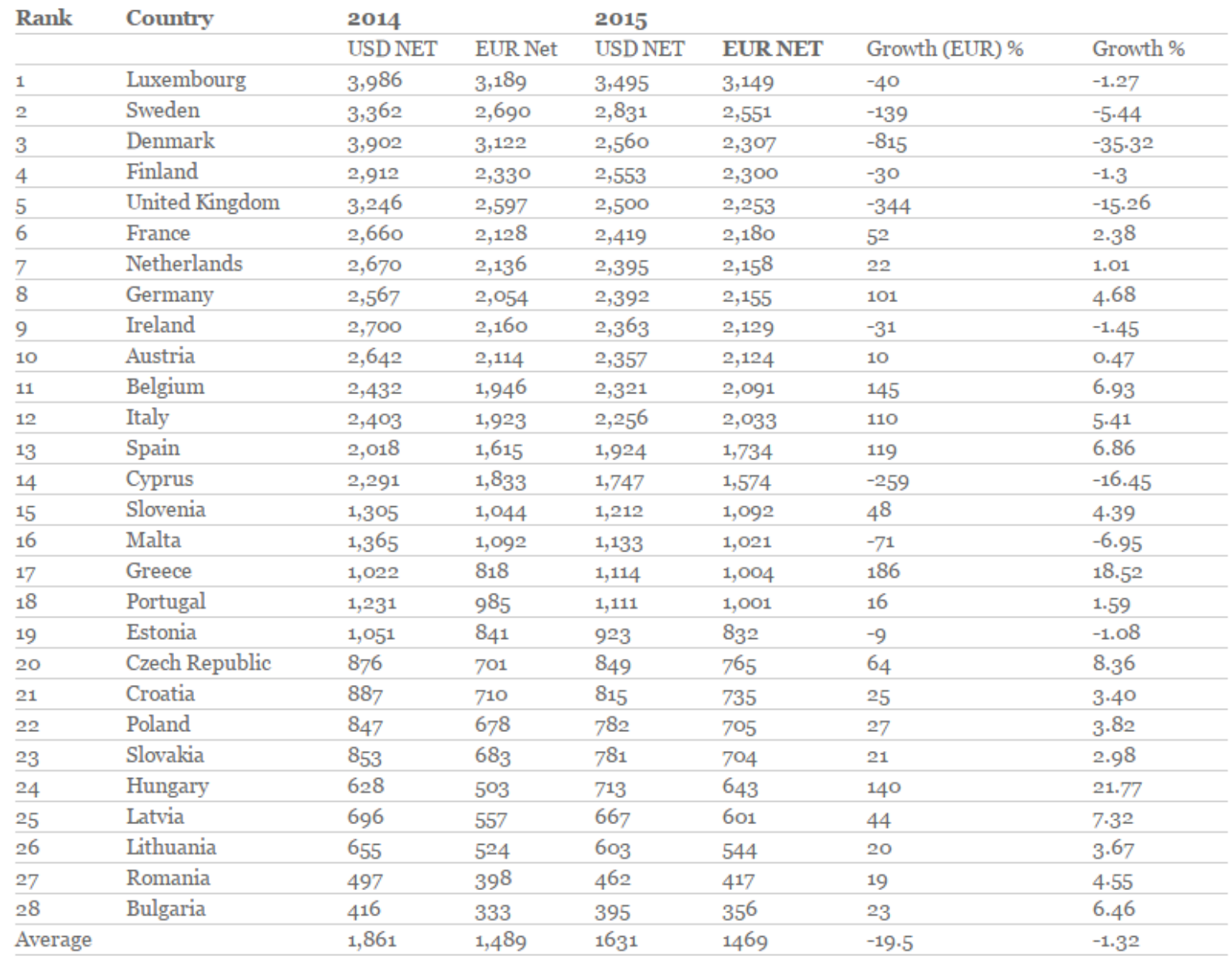

It is also important to consider the salaries of the personnel employed in the biomass power plants, since a number of positions requiring high qualified people with special skills. But the location of the power plant matters, too. Despite the fact the EU promotes a deeper economic integration, the salary levels of the member states are different. For the sake of estimating the personnel costs, Table 3 and Table 4 provide a brief overview. Table 3 suggests some examples of salaries per month in the sector, while Table 4 shows the average salaries in the European Union.

\section{References}

Bioenergy Promotion (2014). Bioenergy Promotion 2: From strategies to activities. Latvian Environmental Investment Fund. Retrieved 2/02/2016, from http://www.bioenergypromotion.net/bsr/publications/bioenergy-promotion-2-from-strategiesto-activities-project-results-2014/at_download/document

Bioenergy Promotion (2014). Business model description. Case: Valtimo municipality in North Karelia. Bioenergy Promotion. Retrieved 2/02/2016, from http://www.bioenergypromotion.net/bsr/publications/business-model-description-casevaltimo-municipality-in-north-karelia/at_download/document

Bioenergy Promotion (2014). Business model description - Lundby bioenergy terminal Sweden. Bioenergy Promotion. Retrieved 2/02/2016, from http://www.bioenergypromotion.net/bsr/publications/business-model-description-lundbybioenergy-terminal-sweden/at_download/document 
Bioenergy Promotion (2014). Business model description - Riese green village. Bioenergy Promotion. Retrieved 2/02/2016, from http://www.bioenergypromotion.net/bsr/publications/business-model-description-riese-greenvillage/at_download/document

Bioenergy Promotion (2014). Business Model for the case - Gdynia transportation system using biogas to transport technology. Bioenergy Promotion. Retrieved 2/02/2016, from http://www.bioenergypromotion.net/bsr/publications/business-model-for-the-case-2013gdynia-transportation-system-using-biogas-to-transport-technology/at_download/document

Bioenergy Promotion (2014). Ludzas Bio-Enerǵija Business model description. Bioenergy Promotion. Retrieved 2/02/2016, from http://www.bioenergypromotion.net/bsr/publications/ludzas-bio-energija-business-modeldescription/at_download/document

Bioenergy Promotion (2014). North Karelia Finland: Creation of jobs and local prosperity with wood chip district heating plant, lowering dependence of external energy sources. Bioenergy Promotion. Retrieved 2/02/2016, from http://www.bioenergypromotion.net/bsr/publications/north-karelia-finland-creation-of-jobsand-local-prosperity-with-wood-chip-district-heating-plant-lowering-dependence-of-externalenergy-sources/at_download/document

Bioenergy Promotion (2014). Skaraborg Sweden - Bioenergy as key driver in agricultural and green business development. Bioenergy Promotion. Retrieved 2/02/2016, from http://www.bioenergypromotion.net/bsr/publications/skaraborg-sweden-bioenergy-as-keydriver-in-agricultural-and-green-business-development/at_download/document

Biomass Energy Europe (2011). Final Report. BEE. Retrieved 2/02/2016, from http://www.eu-bee.eu/_ACC/_components/ATLANTIS-

DigiStore/Final\%20report\%20BEE18c0.pdf?item=digistorefile;264814;837\&params=open;ga $\underline{\text { llery }}$

European Commission (2014). Commission Regulation (EU) No 651/2014 of 17 June 2014 declaring certain categories of aid compatible with the internal market in application of Articles 107 and 108 of the Treaty Text with EEA relevance. European Commission. Retrieved 2/02/2016, from http://eur-lex.europa.eu/legalcontent/EN/TXT/PDF/?uri=CELEX:32014R0651\&from=EN

Investopedia http://www.investopedia.com/ Last accessed 2/02/2016.

IRENA (2012). Biomass for Power Generation. IRENA Working Paper: Renewable Energy Technologies: Cost Analysis Series. Retrieved 2/02/2016, from https://www.irena.org/DocumentDownloads/Publications/RE_Technologies_Cost_AnalysisBIOMASS.pdf

Missouri Department of Conservation (2010). Missouri Woody Biomass Harvesting: Best Management Practices Manual. Missouri Department of Conservation. MDC. Retrieved 2/02/2016, from https://mdc.mo.gov/sites/default/files/resources/2010/09/woody_biomass_harvesting_bmp_bo ok.pdf

Missouri Department of Natural Resources (2012). Feasibility Study for a Biomass Electrical Power Plant in the Viburnum Region. Viburnum Economic Development Area Corporation.

"The European Commission support for the production of this publication does not constitute an endorsement of the contents which reflects the views only of the authors, and the Commission cannot be held responsible for any use which may be made of the information contained therein." 
Retrieved 2/02/2016, from https://energy.mo.gov/energy/docs/G11-SEP-RES-

16VEDACFinalReport.pdf 


\title{
MODULE 3: BIOMASS
}

CHAPTER 2. Economic aspects.

Subchapter 2.3.: Analysis of economic efficiency and profitability.

\author{
Dr. Zsolt Radics \\ Geolin Co., Hungary
}

Summary: The subchapter points out the main factors of decision making and the affecting agents. Moreover, it presents more practical indexes for measuring the investments.

\section{$\underline{\text { Introduction }}$}

In order to convince the potential investors (such as managers, directors, companies or governmental organizations), a full-detailed analysis needs to be performed to support the decision-making mechanisms. Investment decision is a determination made by directors and/or management as to how, when, where and how much capital will be spent on investment opportunities. The decision often follows research to determine costs and returns for each option. By proving the economic efficiency and profitability of e.g. a biomass-based power plant, they may decide to invest money in green energy.

\section{Main factors during decision making}

- Time horizon: approximately 25-30 years

- Return on investment in the energy sector: more than 10 years

- The amount of money required to be invested: 3-4 M€ for a biomass power plant (1 MW)

- Opportunities and risks: the environment of the implementation is determined by the international and the EU policies and by the energy policy of a given country. Therefore, it is stable due to the (specific) laws and regulations.

\section{Practical indexes to measure the investments}

As it was already introduced in the previous modules, there is a list of financial indexes or parameters typically used to define the economic viability of an industrial installation investment. Although some of them have been already defined, the main indexes used to analyse the viability of biomass installations are:

- ROI (Return On Investment): A performance measure used to evaluate the efficiency of an investment or to compare the efficiency of a number of different investments. ROI measures the amount of return on an investment relative to the investment's cost. To calculate ROI, the benefit (or return) of an investment is divided by the cost of the investment, and the result is expressed as a percentage or a ratio.

The return on investment formula:

$$
R O I=\frac{\text { (Gain from Investment }- \text { Cost of Investment })}{\text { Cost of Investment }}
$$


In the above formula, 'Gain from Investment' refers to the proceeds obtained from the sale of the investment of interest. Because ROI is measured as a percentage, it can be easily compared with returns from other investments, allowing one to measure a variety of types of investments against one another.

- ROA (Return on Assets): An indicator of how profitable a company is relative to its total assets. ROA gives an idea on how efficient management is a company at using its assets to generate earnings. Calculated by dividing a company's annual earnings by its total assets, ROA is displayed as a percentage. Sometimes this indx is referred to as 'return on investment', but one should keep in mind that is not the same as ROI since the calculation method is similar, but different!

The formula for return on assets is:

$$
R O A=\frac{\text { Net Income }}{\text { Total Assets }}
$$

- ROCE (Return On Capital Employed): Return on Capital Employed (ROCE) is a financial ratio that measures a company's profitability and the efficiency with which its capital is employed. ROCE is calculated as:

$$
\text { ROCE }=\frac{\text { Earnings Before Interest and Tax }(E B I T)}{\text { Capital Employed }}
$$

'Capital Employed' as shown in the denominator is the sum of shareholders' equity and debt liabilities; it can be simplified as (Total Assets - Current Liabilities). Instead of using capital employed at an arbitrary point in time, analysts and investors often calculate ROCE based on 'Average Capital Employed,' which takes the average of opening and closing capital employed for the time period.

A higher ROCE indicates more efficient use of capital. ROCE should be higher than the company's capital cost; otherwise it indicates that the company is not employing its capital effectively and is not generating shareholder value.

- EVA (Economic Value Added): A measure of a company's financial performance based on the residual wealth calculated by deducting cost of capital from its operating profit (adjusted for taxes on a cash basis). Also referred to as 'economic profit'.

The formula for calculating EVA is as follows:

$$
\begin{gathered}
\text { EVA }=\text { Net Operating Profit After Taxes }(\text { NOPAT })-(\text { Capital } \\
\times \text { Cost of Capital })
\end{gathered}
$$

\section{Factors affecting decision making}

- Predictability of demand:

- Electricity and heat demand over a 30-year horizon

- Competition in the energy market

- ROI is over 10 years

- $\mathrm{CO}_{2}$ quota

○ Primary legislation (e.g. treaties)

- Secondary legislation (e.g. regulations and directives)

- Level of losses in transmission 


\section{Renewable energy for local development course}

- Reactive power absorption

- Predictability of procurement:

○ At the start: availability of competent professionals and power plant site

- Site: environmental plant, settlement, development plans

- Staff: qualified managers (construction and operation), professional installers

○ In the short term: a modern power plant technology is available

- Power plant technology: supply, modernity, reliability, references, long-term use.

- In the medium term: availability of permits, availability of operating staff

- Licensing: land use, environmental protection, disaster recovery, construction licensing, occupancy authorization, business (operating) license.

- Staff: professional operators and maintenance staff.

○ In the long term: availability of competitive fuel, availability of the power plant (maintenance, troubleshooting, modernity, profitability, etc.)

- Fuel purchasing: price, storage costs.

- Predictability of financial markets:

- Interest rates

- Bank loans and credits

- Tender opportunities

- Maturity date

○ Risk sharing

- Guarantees

- Margin

○ Repayment ability

o Funding by own capital

- Requirements for an investment:

○ Experienced engineering background: power plant, gas network, electrical network, construction, hydraulic engineering and proficiency in ecology.

- Legal and economic background.

$\circ$ Experience in project management.

- Strong financial background.

- Duration (greatly depends on country-specific laws):

- Site selection, land purchase: 1 to 2 years

- Decision-preparing process, internal decision: 0.5 years

- Permitting processes: 1 to 5 years in the OECD countries, but it is widely depends on national laws and regulations. In the EU, the average length of permitting processes (from first to last) is 2 years.

- Construction, installation: 2 to 2.5 years.

- By knowing each factor one may move forward and look at other decision-affecting factors and start planning

- In order to support planning, the investor and the given stakeholders should be aware of the general project cycle of a biomass-based investment. To support the learning, Figure 1 presents this project-cycle with certain supplies, demands, financial needs and sales opportunities. 


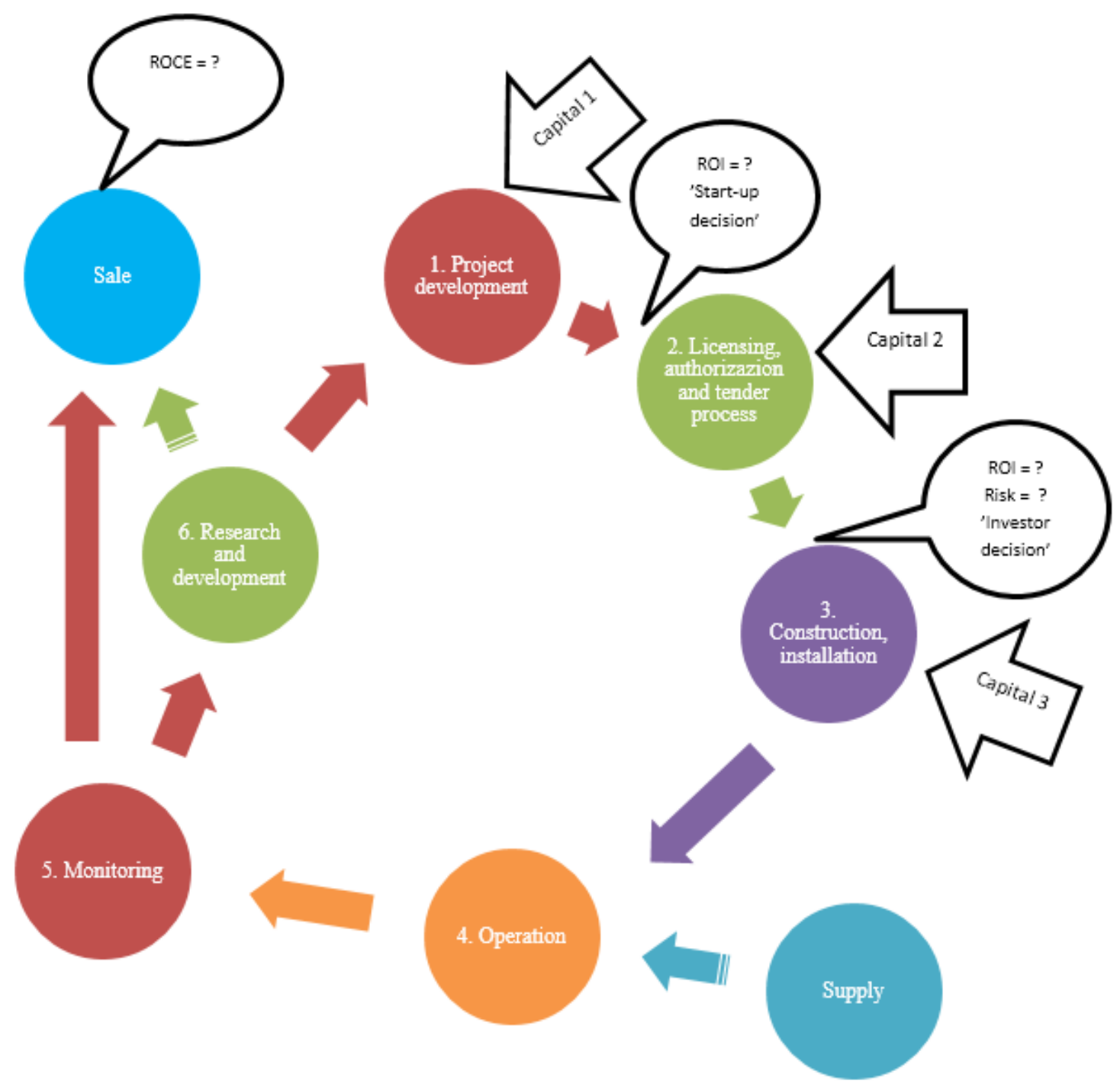

Figure 1. The project-cycle of a biomass power plant-related investment.

\section{References}

Chang, J. (ed.) (2010). Biomass to Renewable Energy Processes. CRC Press.

Dzikuć, M., \& Łasiński, K. (2014). Technical and Economic Aspects of Biomass Co-Firing in Coal-Fired Boilers. International Journal of Applied Mechanics and Engineering, Volume 19, Issue 4, 849-855.

Gergely, S. (2012). Biomasszatüzelés. Károly Róbert Főiskola.

Investopedia http://www.investopedia.com/ Last accessed 2/02/2016.

Rosillo-Calle, F.; de Groot, P.; Hemstock, S. L., \& Woods, J. (eds.) (2007). The Biomass Assessment Handbook: Bioenergy for a Sustainable Environment. Earthscan.

Wichtmann, W., \& Wichmann, S. (2011). Environmental, Social and Economic Aspects of a Sustainable Biomass Production. Journal of Sustainable Energy \& Environment Special Issue, $77-81$. 


\title{
MODULE 3: BIOMASS
}

CHAPTER 3. Social and environmental aspects for rural development.

Subchapter 3.1.: Assessment of environmental impact. Emissions and Life Cycle Analysis.

\author{
Dr. Zsolt Radics \\ Geolin Co., Hungary
}

\begin{abstract}
Summary: Students can learn the environmental concerns and effects regarding biomass utilization. The course participant can also get to know the principles and indexes to prepare a Life Cycle Assessment (LCA) in this context. Furthermore, they can read about the biomassto-energy supply chain operations and can get familiar with the social and rural development impacts of biomass power plants. In the final section a vision for future of biomass is delineated.
\end{abstract}

\section{$\underline{\text { Environmental concerns and effects - an introduction }}$}

- Biodiversity: can be affected by the conversion of natural habitats (transforming a natural forest to a plantation monoculture, for example) and degradation (by removing deadwood, for example). The former poses the bigger environmental threat, though both can reduce the number of plants and animal species.

- Soil quality: can deteriorate through acidification, land erosion, the release of chemicals, or a change in the balance of nutrients. Emissions to soil may also pollute groundwater.

- Water habitats: can be degraded by emissions of nutrients, soil particles, acidic compounds, and chemicals, and by damage to the shorelines that protect them.

- Waste: since most types of waste present an environmental problem if not reused or recycled, using waste for energy production is generally seen as preferable to landfills. Several countries have prohibited landfills and many also have strict rules covering emissions of harmful substances from waste incinerators, making the use of waste biomass for energy an attractive option.

- Agricultural residues and energy crops: Most types of agricultural biomass carry comparatively low environmental risks, though much depends on the agricultural practices followed. Eutrophication from the over-use of fertilizers, the release of chemicals into soil and water, and monoculturization are all potential risks, though they are no different to those faced and managed in any large-scale agricultural production. Therefore, as long as there are sufficient safeguards and regulations and best-practice management guidelines, the environmental impact should be no greater than that of ordinary agricultural production, providing there is no change of land use. This holds true both for residues, which are a by-product so do not pose any additional environmental risks, and energy crops, which generally require less fertilizer and chemicals than food and feed crops. In Europe, biomass from agriculture will largely be produced domestically due to its low transportability, helping to ensure sound management practices. 
- Forestry: The removal of some types of forest biomass (for example harvest residues or stumps) can reduce the level of available nutrients, cause acidification, increase soil erosion, and affect biodiversity, especially at high extraction rates. This is largely because the amount of available deadwood decreases and because the soil is disturbed. As a result, many countries have established regulation that limits the extent to which these residues and stumps can be removed from the forest. The share of residues that can be removed varies. Sweden is at the high end of the spectrum and allows forest owners to remove about $70 \%$ of the residues. The supply increase scenario described in the supply chapter of this module has taken the uncertainty of how much residues can be sustainably removed into account through assuming that only $20 \%$ of all technically available forest residues outside of Scandinavia is removed (half the assumed Swedish extraction rates). Illegal and unsustainable logging, whether for domestic use or export, often raises environmental concerns. If there are enough cheap supplies from other types of forestry, intensive or traditional, illegal logging may become less economically attractive and, therefore, less prevalent.

- Plantations: The main environmental issues biomass installations raise are similar to those encountered in intensive farming. For example, they create a monoculture as almost all other plant species are suppressed, and can result in increased use of fertilizers and chemicals, erosion, and, in warm and dry climates, lower groundwater levels. These risks need to be weighed against the carbon abatement potential of plantations. One should note that biomass from plantations could come as either a by-product from other production, e.g. of rubber or cocoa, or as the main product from dedicated 'energy tree' plantations. These two cases may differ in environmental and climate impact, not least depending on how production emissions are allocated between main products and residues when fuel production is not the main purpose of the plantation. In Europe, current agricultural and forestry management practices are generally regarded as environmentally sound. In developing countries, the issue is more complex and there are examples of both good and bad management practices. Larger-scale production, as well as the introduction of new technologies and processes, will no doubt surface new challenges that will need to be monitored and managed in all geographies.

\section{Emissions}

Nineteen studies, including three types of biomass-based technologies (co-combustion (COCOMB) with a fossil fuel, direct combustion (COMB) and gasification (IBGCC)), were addressed in a study made by Roberto Turconi, Alessio Boldrin and Thomas Astrup. All reviewed studies reported GHG emission factors, while 14 also considered $\mathrm{NOx}$ and $\mathrm{SO}_{2}$ emissions. Contributions from individual life cycle phases for all three compounds were provided in only 8 studies. In studies assessing residual biomass, all impacts were associated with power plant operation, i.e., assuming a 'zero burden' boundary upstream of the plant (see the discussion regarding this aspect). Emissions related to infrastructures were negligible for all three compounds.

The reported GHG emission factors showed high variability: 25-130 kg CO 2 -eq/MWh (CO-

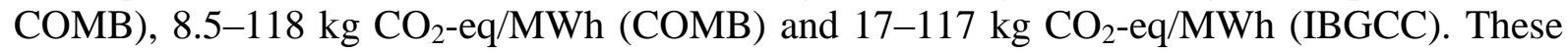
data do not include biogenic $\mathrm{CO}_{2}$ emissions because it is a common LCA practice to assume a global warming characterization factor for biogenic $\mathrm{CO}_{2}$ of zero. However, when emission factors are used for GHG emission reporting within the IPCC (Intergovernmental Panel on Climate Change) framework, biogenic $\mathrm{CO}_{2}$ is then included because the $\mathrm{CO}_{2}$ uptake by biomass is accounted for within the AFOLU (i.e., Agriculture, Forestry, and Other Land Use) 
sector. Emission factors for NOx were in the range of $0.08-1.7 \mathrm{~kg} \mathrm{NOx} / \mathrm{MWh}$, with the highest values related to COMB and the lowest values associated with CO-COMB. In addition to the FGC (Flue gas cleaning) system, NOx emissions were strongly related to the type of biomass. In the provision phase, emissions occurred from the use of machinery during cultivation and harvesting in the case of energy crops, whereas no emissions were typically associated with wood residues (adopting a zero burden approach). Combustion of furniture wood residues may result in larger emissions due to the nitrogen content of the fuel. Emissions of $\mathrm{SO}_{2}$ also showed high variability for all three technologies assessed, ranging from 0.03 to $0.94 \mathrm{~kg} \mathrm{SO}_{2} / \mathrm{MWh}$, with the largest contribution from fuel provision.

Table 1. Comparison of pollutant emissions regarding the combustion plants based on different energy sources in the case of medium emissions. (Source: Tóth - Bulla - Nagy, 2011)

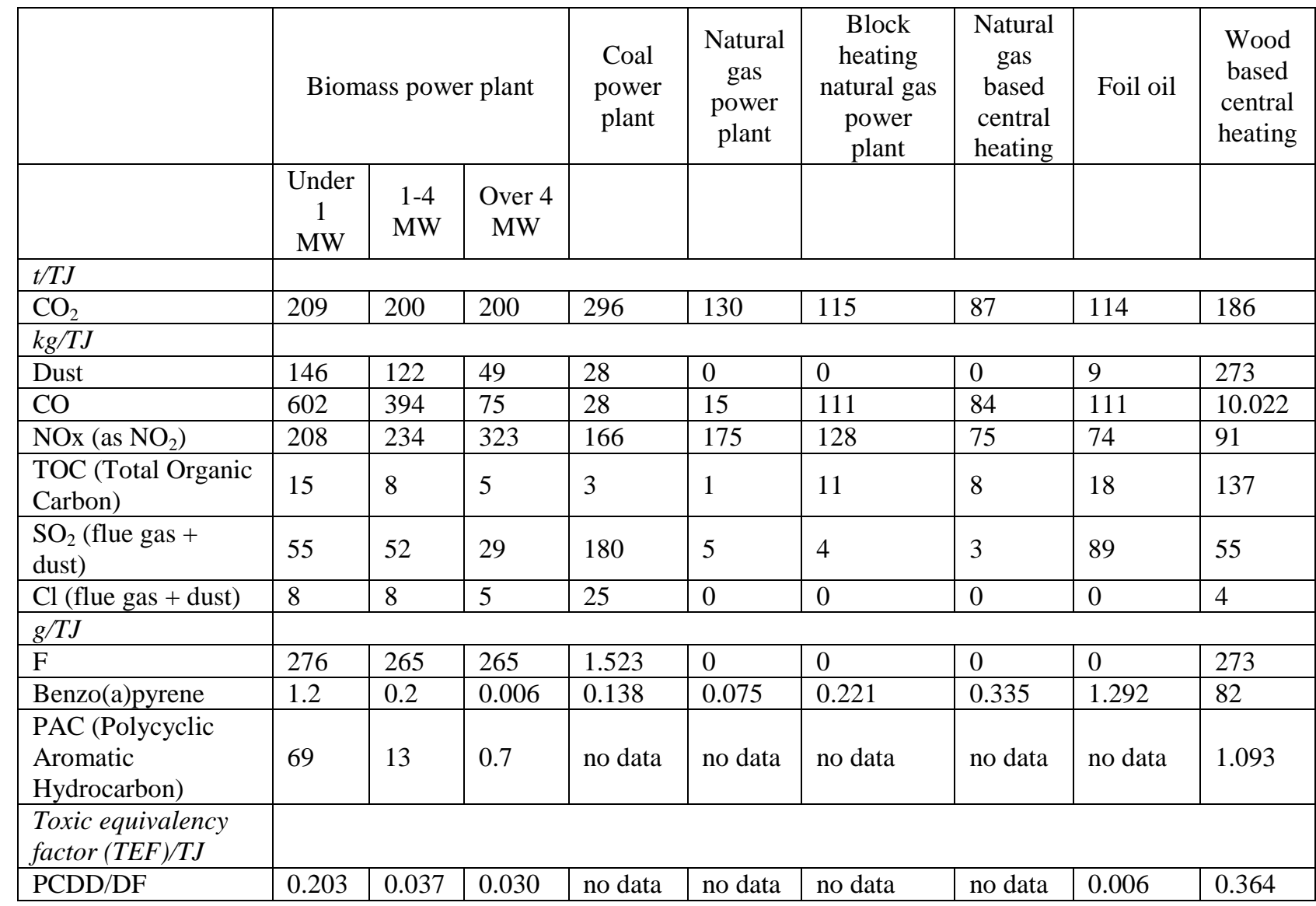

The assessment of GHG emission savings of biomass is based on the following formula, which was published in a European Commission report ${ }^{1}$ :

$$
E=e_{e c}+e_{l}+e_{p}+e_{t d}+e_{u}+e_{s c a}+e_{c c s}+e_{c c r}
$$

where:

$E=$ total emissions from the use of the fuel before energy conversion

$e_{e c}=$ emissions from the extraction or cultivation of raw materials

$e_{l}=$ annualised emissions from carbon stock changes caused by land use change

$e_{p}=$ emissions from processing

\footnotetext{
${ }^{1}$ http://eur-lex.europa.eu/LexUriServ/LexUriServ.do?uri=COM:2010:0011:FIN:EN:PDF
}

"The European Commission support for the production of this publication does not constitute an endorsement of the contents which reflects the views only of the authors, and the Commission cannot be held responsible for any use which may be made of the information contained therein." 
$e_{t d}=$ emissions from transport and distribution

$e_{u}=$ emissions from the fuel in use

$e_{s c a}=$ emission savings from soil carbon accumulation via improved agricultural management

$e_{c c s}=$ emission savings from carbon capture and geological storage

$e_{c c r}=$ emission savings from carbon capture and replacement

\section{Principles of Life Cycle Assessment:}

- Life cycle perspective: LCA considers the entire life cycle of a product, from raw material extraction and acquisition, through energy and material production and manufacturing, to use and end-of-life treatment and final disposal. Through such a systematic overview and perspective, the shifting of a potential environmental burden between life cycle stages or individual processes can be identified and possibly avoided.

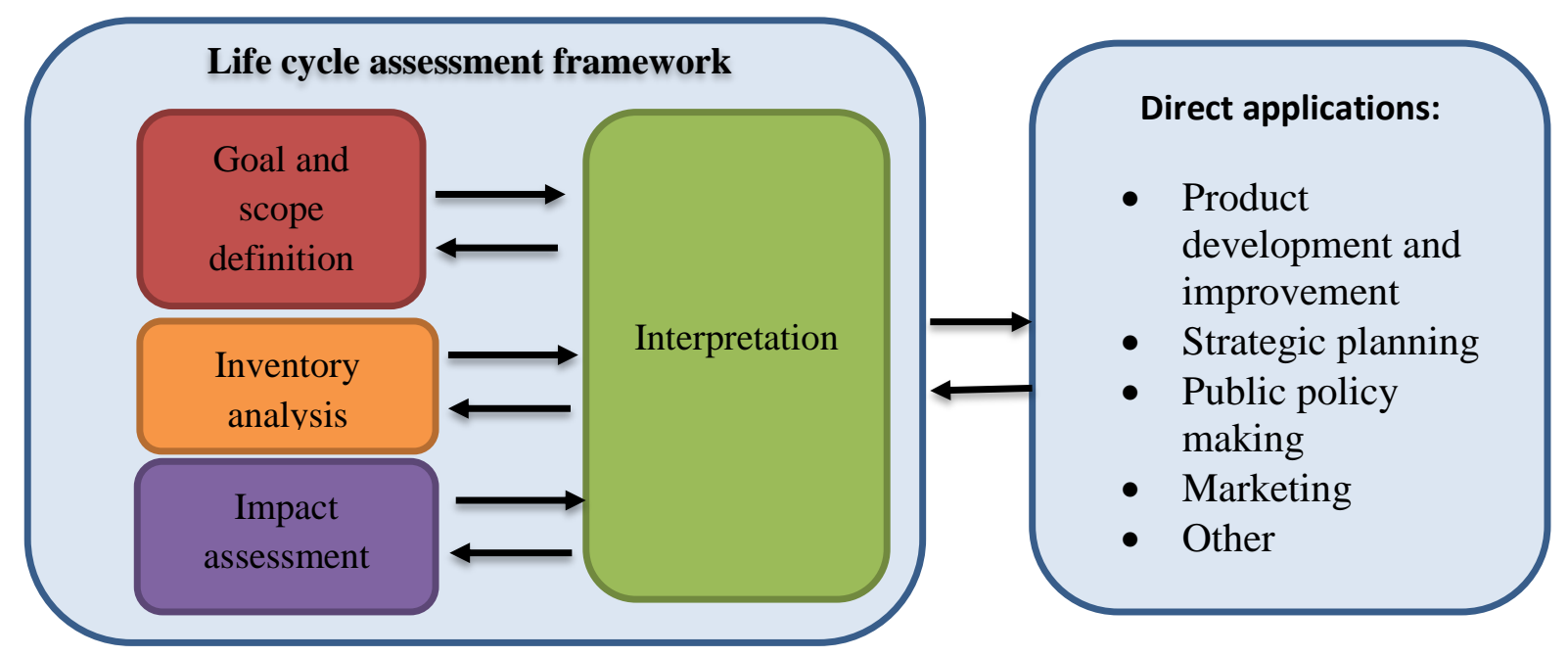

Figure 1. Stages of LCA.

- Environmental focus: LCA addresses the environmental aspects and impacts of a product system. Economic and social aspects and impacts are, typically, outside the scope of the LCA. Other tools may be combined with LCA for more extensive assessments.

- Relative approach and functional unit: LCA is a relative approach, which is structured around a functional unit. This functional unit defines what is being studied.

- Iterative approach: LCA is an iterative technique. The individual phases of an LCA use results of the other phases. The iterative approach within and between the phases contributes to the comprehensiveness and consistency of the study and the reported results.

- Transparency: Due to the inherent complexity in LCA, transparency is an important guiding principle in executing LCAs, in order to ensure a proper interpretation of the results.

- Comprehensiveness: LCA considers all attributes or aspects of natural environment, human health and resources. By considering all attributes and aspects within one study in a cross-media perspective, potential trade-offs can be identified and assessed.

- Priority of scientific approach: Decisions within an LCA are preferably based on natural science. If this is not possible, other scientific approaches (e.g. from social and economic sciences) may be used or international conventions may be referred to. If neither a scientific basis exists nor a justification based on other scientific approaches or 
international conventions is possible, then, as appropriate, decisions may be based on value choices.

\section{$\underline{\text { Indexes to prepare a Life Cycle Analysis }}$}

\section{Energy payback time}

Energy payback time (EPBT) means years to recover primary energy consumption throughout life cycle of a power plant by its own energy production. Both the total primary energy requirement and the annual power generation concerned as primary energy. Energy payback time (year) of a system is a ratio of Total primary energy requirement of the system throughout its life cycle to annual primary energy generated by a system. To convert annual power generation $(\mathrm{kWh})$ of electricity to primary energy looked at the efficiency of power plants in the assumed country.

\section{2. $\mathrm{CO}_{2}$ payback time}

$\mathrm{CO}_{2}$ payback time (PBT) is calculated from estimates of $\mathrm{CO}_{2}$ emissions during construction and operation in a large scale fossil fuel combustion. For example, the definition of $\mathrm{CO}_{2}$ payback time, for biomass versus coal fired power plant is defined as follows:

$$
\mathrm{CO}_{2} \mathrm{PBT}=\frac{\left[\left(C_{\text {biomass }} / E_{\text {biomass }}\right)-\left(C_{\text {coal }} / E_{\text {coal }}\right)\right]}{\left[\left(O_{\text {coal }} / E_{\text {coal }}\right)-\left(O_{\text {biomass }} / E_{\text {biomass }}\right)\right]}
$$

where: $C=\mathrm{CO}_{2}$ emissions from material production and its construction $\left(\mathrm{g}-\mathrm{CO}_{2}\right) ; O=\mathrm{CO}_{2}$ emissions from generating (operating) plant ( $\mathrm{g}-\mathrm{CO}_{2} /$ year); $E=$ electricity generated annually $(\mathrm{kWh} /$ year).

\section{Energy intensity}

The energy intensity for a plant of power rating $(P)$ and load factor $(\lambda)$ is defined as the ratio of the energy requirement $(E)$ for construction, operation and decommissioning and the electricity output of the plant over its life time $(T)$.

$$
\text { Energy intensity }=\frac{E}{P \times 8760 \times \lambda \times T}
$$

\section{Biomass-to-energy supply chain operations}

Supply Chain Management (SCM) plays a critical role in the management of bioenergy production processes. Biomass Supply Chain Management has been defined as the integrated management of bioenergy production from harvesting biomaterials to energy conversion facilities. Biomass energy supply chain differs from traditional supply chains in several ways. Among them, it is to note the seasonal availability of agricultural biomass, the low energy density of the biomass, the demand variations due to uncertain energy production performance and the variability of biomass materials, which has implications for transport and storage. Thus, the main objectives of the biomass supply chain management are to minimize costs, environmental impacts of the supply chain, and ensure continuous feedstock supply.

The parties involved in a biomass energy supply chain are: the supplier of biomass, transportation and distribution entities, energy production facility developers and operators, the government and utility firms who provide the incentives, and the end users. In this sense, a typical bioenergy supply chain is comprised of five main components: harvesting and collection, pre-treatment, storage, transport, and energy conversion. 
Figure 2. Operational components of a biomass supply chain. (Source: Mafakheri - Nasri, 2014)

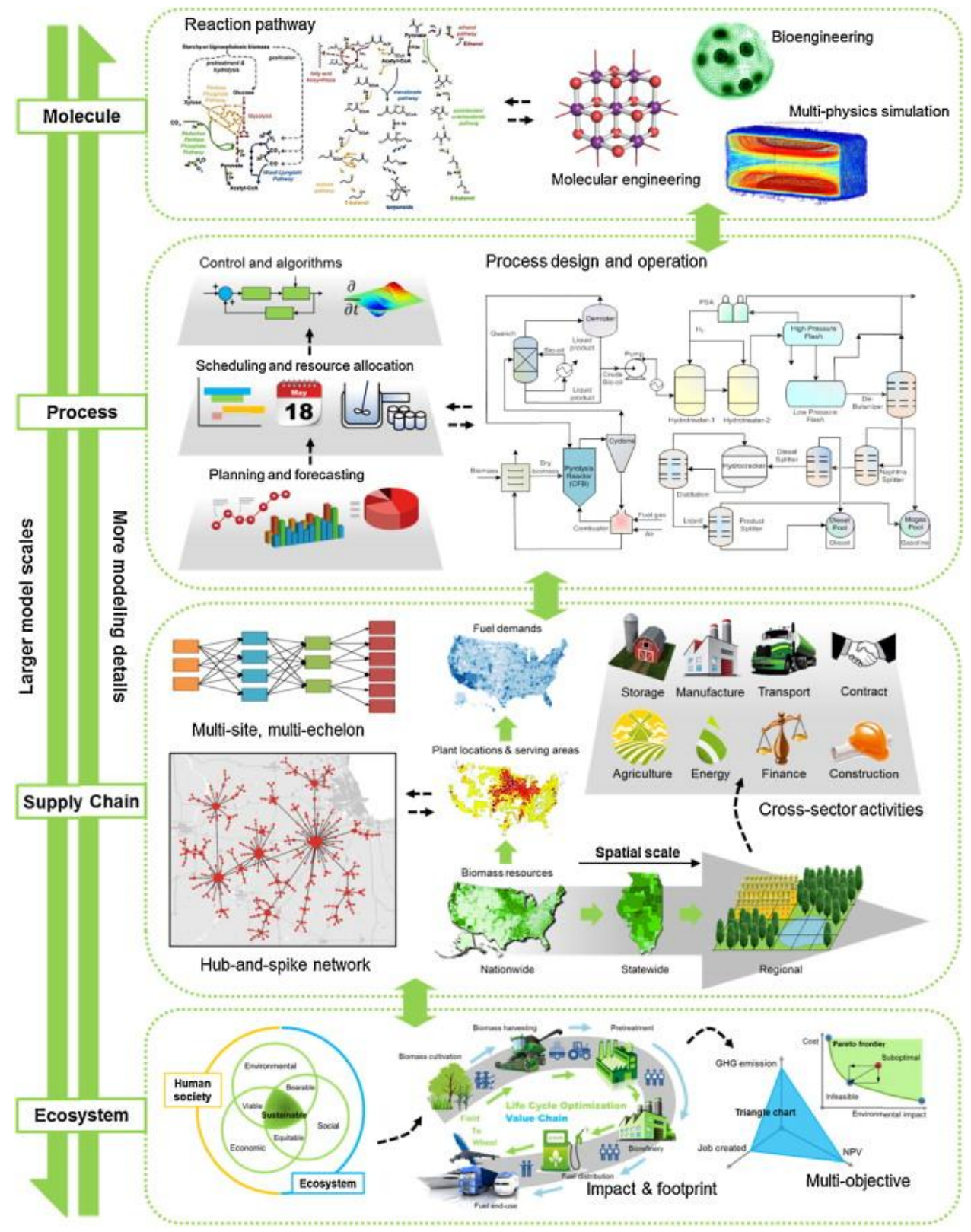

Figure 3. Illustration of multi-scale modeling and optimization of biofuel supply chains ${ }^{2}$.

(Source: Yue - You - Snyder, 2013)

\footnotetext{
${ }^{2}$ For the full-detailed image see http://www.sciencedirect.com/science/article/pii/S0098135413003670
}

"The European Commission support for the production of this publication does not constitute an endorsement of the contents which reflects the views only of the authors, and the Commission cannot be held responsible for any use which may be made of the information contained therein." 
Figure 3 illustrates the multi-scale modelling and optimization of biofuel supply chains in order to give a general summarization in connection with the above mentioned ideas.

1. Biomass harvesting and collection: In this component of biomass supply chains, the main decisions to deal with are allocation of land, harvest scheduling, and biomass collection planning based on the analysis of biomass soil/moisture contents, climatic conditions, land availability, and bioenergy demand.

2. Biomass pre-treatment: Pre-treatment is a mechanical or chemical process (or a combination of them) that converts biomass into denser energy carriers not only to increase its energy conversion rate but also to facilitate handling, storage and transportation, and to reduce the associated costs.

3. Biomass storage: Typical decisions related to storage component of biomass supply chains are analysis of the location of storage facilities and storage capacity planning/scheduling. Choosing an appropriate location for biomass storage facilities is not only influenced by the type and characteristics of biomass materials, but is also constrained by transportation options.

4. Biomass transport: the transport phase in biomass supply chain is associated with various models developed in order to analyse the feasibility of the alternative routes, decide on the means of transport (types, their capacity and schedule), minimize supply chain costs and travel time, and to minimize the environmental impacts of supply chain activities.

5. Biomass energy conversion: In the conversion stage, decision makers need to deal with decisions as varied as location analysis for conversion facilities, conversion technology selection, and capital and operational planning of the conversion facilities.

These five stages are summarized in Figure 4.

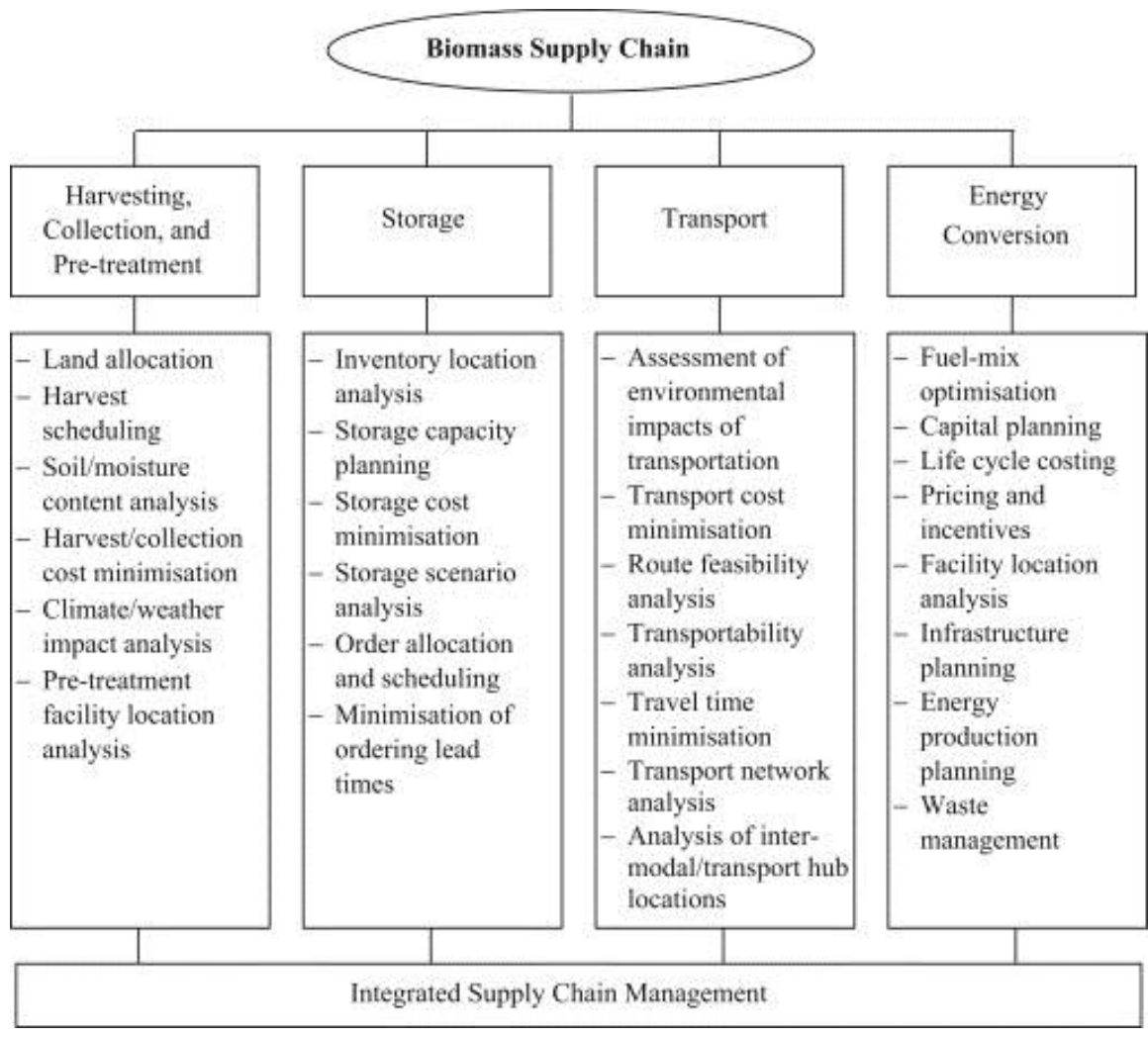

Figure 4. A taxonomy of biomass supply chain operations management models. (Source:

$$
\text { Mafakheri - Nasri. 2014) }
$$


Challenges associated with biomass supply chain operations by Mafakheri and Nasri (2014)

1. Technical and technological:

- Unavailability of biomass

- Seasonality of biomass

- Inefficiencies of conversion facilities

- Infeasibility of large-scale production

- Conflicting decisions (technologies, locations, and routes)

- Complex location analysis (source points, inventory facilities, and production plants)

2. Financial:

- High capital costs (a thirst for operational savings)

- The limits for the economy of scale

- Unavailability and complexity of life cycle costing data

- Lack of infrastructural requirements

- Inflexibility to energy demand

- Risks associated with new technologies (insurability, performance, rate of return)

3. Social:

- Extended market volatilities (energy and food markets)

- Lack of participatory decision making

- Lack of public/community awareness

- Local supply chain impacts vs. global benefits

- Health and safety risks

- Conflicts with food supply chain

- Extra pressure on transport sector

- Decreasing the aesthetics of rural areas

4. Environmental:

- Loss of biodiversity and natural habitats

- Soil overexploitation and degradation

- GHG emissions throughout the supply chain activities

- Excessive use of water

- Unavailability of data on environmental impacts

5. Policy and regulatory:

- Impact of fossil fuel tax on biomass transport

- Lack of incentives to create competition among bioenergy producers

- Focus on technology options and less attention to types of biomass materials

- Lack of support for sustainable supply chain solutions

6. Institutional and organizational:

- Varied ownership arrangements and priorities among supply chain parties

- Lack of supply chain standards

- Impact of organizational norms and rules on decision making and supply chain coordination

- Immaturity of change management practices in biomass supply chains

\section{References}

Ali, M. (2013). Climate Change Impacts on Plant Biomass Growth. Springer. 
Altawell, N. (2014). The Selection Process of Biomass Materials for the Production of BioFuels and Co-firing. Wiley.

BERC (2011). Particulate Matter Emissions-Control Options for Wood Boiler Systems. Biomass Energy Resource Center. Retrieved 2/02/2016, from http://www.biomasscenter.org/images/stories/FSE_PM_Emissions.pdf

Bíró, Borbála (2010). Biomassza hasznositás. Edutus Főiskola.

Breeze, P. (2004). The Future of Global Biomass Power Generation: The technology, economics and impact of biomass power generation. Business Insights.

BTG biomass technology group BV (2009). Guideline for Safe and Eco-friendly Biomass Gasification. BTG biomass technology group $B V$. Retrieved 2/02/2016, from http://www.gasification-guide.eu/gsg_uploads/documenten/D10_Final-Guideline.pdf

Caputo, A. C.; Palumbo, M.; Plagagge, M., \& Scacchia, F. (2005). Economics of biomass energy utilization in combustion and gasification plants: effects of logistic variables. Biomass and Bioenergy, 28, 35-51.

Dahlquist, E. (ed.) (2012). Biomass as Energy Source: Resources, Systems and Applications. CRC Press.

Dzikuć, M., \& Łasiński, K. (2014). Technical and Economic Aspects of Biomass Co-Firing in Coal-Fired Boilers. International Journal of Applied Mechanics and Engineering, Volume 19, Issue 4, 849-855.

European Climate Foundation (2010). Biomass for heat and power - opportunity and economics. European Climate Foundation. Retrieved 2/02/2016, from http://www.europeanclimate.org/documents/Biomass_report___Final.pdf

European Environment Agency (2006). How much bioenergy can Europe produce without harming the environment? EEA Report. Retrieved 2/02/2016, from http://www.eea.europa.eu/publications/eea_report_2006_7/at_download/file

FAO (2010). What woodfuels can do to mitigate climate change. FAO Forestry Paper, 162. Retrieved 2/02/2016, from http://www.fao.org/docrep/013/i1756e/i1756e00.pdf

Gikonyo, B. (ed.) (2015). Fuel Production from Non-Food Biomass: Corn Stover. Apple Academic Press

GNESD (2011). Bioenergy: The potential for rural development and poverty alleviation. Global Network on Energy for Sustainable Development (GNESD). Retrieved 2/02/2016, from http://www.gnesd.org//media/Sites/GNESD/Publication\%20pdfs/Bioenergy_PotentialForDevelopment_SPM.ashx?1 $\underline{\mathrm{a}=\mathrm{da}}$.

Gyulai, I. (2009). A biomassza-dilemma. Magyar Természetvédők Szövetsége.

Hakeem, K. R.; Mohammad, J., \& Alothman, O. Y. (eds.) (2015). Agricultural Biomass Based Potential Materials. Springer. 
Hiete, M.; Ludwig, J.; Bidart, C., \& Schultmann. F. (eds.) (2010). Challenges for Sustainable Biomass Utilisation: Proceedings of the Chilean-German Biociclo Workshop (Karlsruhe, 26.03.2009). KIT Scientific Publishing.

Innes, J. L.; Beniston, M., \& Verstraete, M. M. (eds.) (2000). Biomass Burning and Its InterRelationships with the Climate System. Springer.

IRENA (2012). Biomass for Power Generation. IRENA Working Paper: Renewable Energy Technologies: Cost Analysis Series. Retrieved 2/02/2016, from https://www.irena.org/DocumentDownloads/Publications/RE_Technologies_Cost_AnalysisBIOMASS.pdf

Jansen, R. A. (2012). Second Generation Biofuels and Biomass: Essential Guide for Investors, Scientists and Decision Makers. Wiley.

Juhász, Á. et. al. (2009). Megújuló energiák. Sprinter Kiadói Csoport.

Karlsson, I., \& Rydén, L. (eds.) (2012). Rural Development and Land Use. The Baltic University Programme, Uppsala University.

Klatka, S., \& Johansson, M. (2014). Recommendations for the Stimulation of Regional Value Chains in Bioenergy Sector. Bioenergy Promotion. Retrieved 2/02/2016, from http://www.bioenergypromotion.net/bsr/publications/recommendations-for-the-stimulationof-regional-value-chains-in-bioenergy-sector/at_download/document

Kleinschmit, J. (2007). Biofueling Rural Development: Making the Case for Linking Biofuel Production to Rural Revitalization. Carsey Institute, Policy Brief No. 5. Retrieved 2/02/2016, from http://scholars.unh.edu/cgi/viewcontent.cgi?article=1019\&context=carsey

Kot, S., \& Ślusarczyk, B. (2013). Aspects of Logistics in Biomass Supply for Energy Production. Applied Mechanics and Materials, Vol. 309, 206-212.

Mafakheri, F., \& Nasiri, F. (2014). Modeling of biomass-to-energy supply chain operations: Applications, challenges and research directions. Energy Policy, Volume 67, 116-126.

Magda, Róbert (2012). Fenntartható fejlödés és természeti erőforrás gazdálkodás. Károly Róbert Főiskola.

Matovic, M. D. (ed.) (2013). Biomass Now - Cultivation and Utilization. InTech.

Matovic, M. D. (ed.) (2013). Biomass Now - Sustainable Growth and Use. InTech.

National Research Council (2011). Renewable Fuel Standard: Potential Economic and Environmental Effects of U.S. Biofuel Policy. Committee on Economic and Environmental Impacts of Increasing Biofuels Production; National Research Council.

Odenberger, I., \& Thek, G. (2010). The Pellet Handbook: The Production and Thermal Utilisation of Pellets. Earthscan.

OECD (2004). Biomass and Agriculture: Sustainability, Markets and Policies. OECD Publishing.

OECD (2012). Linking Renewable Energy to Rural Development. OECD Green Growth Studies, OECD Publishing. 
Openshaw, K. (2010). Can Biomass Power Development? International Institute for

Environment and Development (IIED). Retrieved 2/02/2016, from http://pubs.iied.org/pdfs/14598IIED.pdf

Pappné Vancsó, J. (2010). A biomassza, mint energiaforrás hasznositási lehetöségei, különös tekintettel Magyarországra. $\mathrm{PhD}$ Thesis.

Pehnt, M. (2006). Dynamic life cycle assessment (LCA) of renewable energy technologies. Renewable Energy, 31, 55-71.

Pinheiro, G. et. al. (2012). Sustainable management model for rural electrification: Case study based on biomass solid waste considering the Brazilian regulation policy. Renewable Energy, 37, 379-386.

Riva, G. et. al. (2012). Handbook on Renewable Energy Sources. ENER SUPPLY. Retrieved 2/02/2016, from http://www.ener-supply.eu/downloads/ENER_handbook_en.pdf

Rosillo-Calle, F.; Bajay, S. V. \& Rothman, H. (eds.) (2000). Industrial Uses of Biomass Energy: The Example of Brazil. CRC Press.

Rosillo-Calle, F.; de Groot, P.; Hemstock, S. L., \& Woods, J. (eds.) (2007). The Biomass Assessment Handbook: Bioenergy for a Sustainable Environment. Earthscan.

Röser, D., Asikainen, A., Raulund-Rasmussen, K., \& Stupak, I. (eds.) (2008). Sustainable Use of Forest Biomass for Energy: A Synthesis with Focus on the Baltic and Nordic Region. Springer.

Sheelanere, P., \& Kulshreshtha, S. (2013). Sustainable Biofuel Production: Opportunities for Rural Development. International Journal of Environment and Resource (IJER), Volume 2 Issue 1, 1-13.

Shekhar, N. (2010). Popularization of Biomass Briquettes - A means for Sustainable rural Development. Asian Journal of Management Research. Volume 2 Issue 1, 457-473.

Simpkins, D. (2006). Clean Energy from Wood Residues in Michigan. Discussion Paper. Michigan Biomass Energy Program. Retrieved 2/02/2016, from http://www.michigan.gov/documents/wood_energy_in_michigan--final1_169999_7.pdf

Steininger, K., \& Höltiger, S. (2010). Assessment of the Regional Biomass Potential for the Region East Styria. Rural Biological Resources. Retrieved 2/02/2016, from http://www.rubires.de/ujanyagok/wp3/eaststyria.pdf

Sund Energy AS, commissioned by Nordic Energy Research (2010). Mapping Biogas in the Nordic Countries. Nordic Energy Research. Retrieved 2/02/2016, from http://www.nordicenergy.org/wp-

content/uploads/2012/01/mapping biogas_in_the_nordic_countries_-_final1.pdf

Tallaksen, J. (2011). Guidelines for Developing a Sustainable Biomass Supply Chain. USDA Final Report. Retrieved 2/02/2016, from http://renewables.morris.umn.edu/biomass/documents/USDA_Report/SII_SupplyChain.pdf

Thornley, P. (2015). Maximizing the greenhouse gas reductions from biomass: The role of life cycle assessment. Biomass and Bioenergy, 81, 35-43.

"The European Commission support for the production of this publication does not constitute an endorsement of the contents which reflects the views only of the authors, and the Commission cannot be held responsible for any use which may be made of the information contained therein." 
Tóth, P.; Bulla, M., \& Nagy, G. (2008): Energia és Környezet, UNIVERSITAS- Győr Nonprofit Kft, az eredeti kiadvány 1999. átdolgozott 2008. évi változata alapján.

Tsuda, K. et. al. (2014). Potential accounting of regional biomass resource circulations in Japan: A prospective on regional rural-urban partnerships. Environmental Development, 9, 24-42.

Turconi, R.; Boldrin, A., \& Astrup, T. (2013). Life cycleassessment (LCA) of electricity generation technologies: Overview, comparability and limitations. Renewable and Sustainable Energy Reviews, 28, 555-565.

van Loo, S., \& Koppejan, J. (eds.) (2008). The Handbook of Biomass Combustion and Cofiring. Earthscan.

Varun, B. I. K., \& Prakash, R. (2009). LCA of renewable energy for electricity generation systems - A review. Renewable and Sustainable Energy Reviews, 13, 1067-1073.

Vertès, A. A.; Qureshi, N.; Blaschek, H. P., \& Yukawa, H. (eds.) (2010). Biomass to Biofuels: Strategies for Global Industries. Wiley.

Walderon, K. (ed.) (2014). Advances in Biorefineries: Biomass and Waste Supply Chain Exploitation. Woodhead Publishing.

Wichtmann, W., \& Wichmann, S. (2011). Environmental, Social and Economic Aspects of a Sustainable Biomass Production. Journal of Sustainable Energy \& Environment Special Issue, 77-81.

Yan, J. (2015). Comprehensive Evaluation of Effective Biomass Resource Utilization and Optimal Environmental Policies. Springer.

Yue, D.; You, F., \& Snyder, S. W. (2014). Biomass-to-bioenergy and biofuel supply chain optimization: Overview, key issues and challenges. Computers and Chemical Engineering, 66, 36-56.

Zhu, J. Y.; Zhang, X., \& Pan, X. (eds.) (2011). Sustainable Production of Fuels, Chemicals, and Fibers from Forest Biomass. Oxford University Press. 


\title{
MODULE 3: BIOMASS
}

CHAPTER 3. Social and environmental aspects for rural development.

Subchapter 3.2.: Social and Rural Development impact.

\author{
Dr. Zsolt Radics \\ Geolin Co., Hungary
}

\begin{abstract}
Summary: In addition to the characteristics of social and rural development impact of using biomass energy, the subchapter provides a brief summarization of the above mentioned factors in order to enable explicit learning and critical thinking. Additional facts related to the theme can be found in the remaining chapters.
\end{abstract}

\section{Social and Rural Development impact.}

Concerning the conclusions of the preceding chapters, the following features of biomass related to the social and rural development can be discussed in detail. While the environmental benefits of renewable energy, including bioenergy, are widely accepted, the socio-economic benefits are not so well understood. Investment in renewable energy technologies can usually provide benefits to the whole macro-economy by creating jobs and improving social welfare. From the social perspective, there can be little doubt that bioenergy projects protect existing employment, provide new jobs, give learning opportunities, transfer skills, introduce new skills, and provide training and educational opportunities. In addition, the trend towards distributed energy systems and independent power production using smaller-scale plants and embedded generation should result in a decline in urban drift, once rural communities are able to develop and grow using the new sources of bioenergy available to them.

In general, renewable energy systems are more labour intensive than fossil fuel systems and a higher proportion of the jobs require relatively high skills. To operate and maintain bioenergy plants and provide the fuel, employment opportunities are often created, particularly in rural areas, bringing a new perspective to rural communities. Bioenergy project employment differs from wind, hydro and solar projects where the work activities mainly consist of plant manufacturing, installation and maintenance. Providing the biomass fuel supply and delivering it to the conversion plant is an essential additional component of bioenergy. Therefore, the plant construction jobs tend to represent a smaller proportion relative to the ongoing operation and maintenance jobs. This is advantageous in areas where employment is a major political concern, but since labour is often expensive, then it is a major reason why renewable energy projects often find difficulty in competing on an economic basis.

Biomass can also contribute to the EU energy security, in so far as the majority of biomass demand is met through domestically produced raw material and imports are supplied by diversified sources. In the case of additionally mobilised biomass, there is also a potential for new sources of income along the whole biomass value chain, from cultivation to harvest, processing and conversion into electricity, heating and cooling. This can benefit farmers and forest owners and support rural development. In 2012, the European bioheat and bioelectricity

"The European Commission support for the production of this publication does not constitute an endorsement of the contents which reflects the views only of the authors, and the Commission cannot be held responsible for any use which may be made of the information contained therein." 


\section{Renewable energy for local development course}

sectors generated a total turnover of, at least 3300 million euros, and employed over 374,800 people.

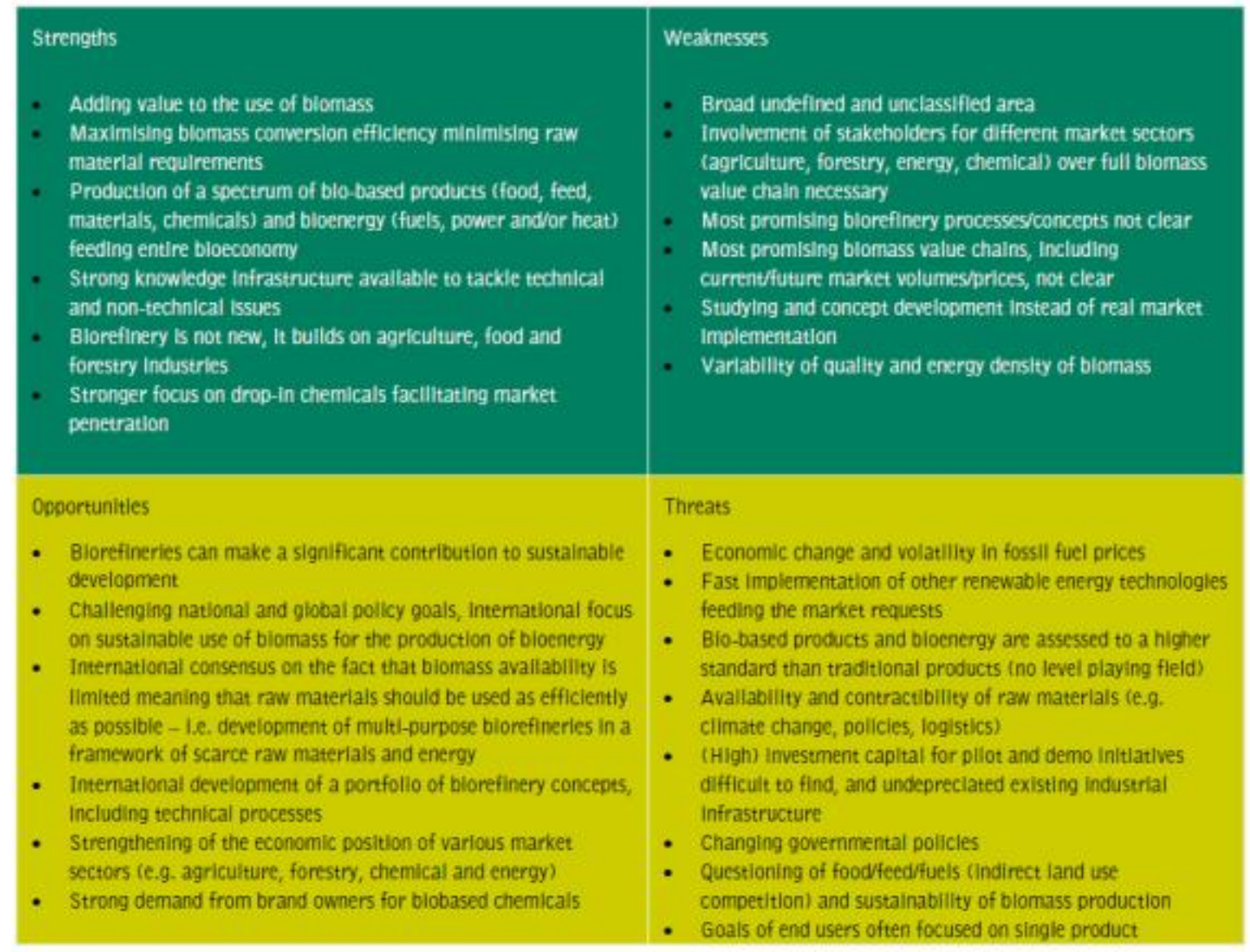

Figure 1. SWOT analysis on biorefineries in general. (Source: IEA, 2012)

A SWOT analysis is a tool that identifies the strengths, weaknesses, opportunities and threats of an organization. Specifically, SWOT is a basic, straightforward model that assesses what an organization can and cannot do as well as its potential opportunities and threats. The method of SWOT analysis is to take the information from an environmental analysis and separate it into internal (strengths and weaknesses) and external issues (opportunities and threats). Once this is completed, SWOT analysis determines what may assist the firm in accomplishing its objectives, and what obstacles must be overcome or minimized to achieve desired results. Figure 1 gives an insight to strengths, weaknesses, opportunities and threats related to the utilization of biorefineries in general.

\section{References}

BTG biomass technology group BV (2009). Guideline for Safe and Eco-friendly Biomass Gasification. BTG biomass technology group $B V$. Retrieved 2/02/2016, from http://www.gasification-guide.eu/gsg_uploads/documenten/D10_Final-Guideline.pdf

Caputo, A. C.; Palumbo, M.; Plagagge, M., \& Scacchia, F. (2005). Economics of biomass energy utilization in combustion and gasification plants: effects of logistic variables. Biomass and Bioenergy, 28, 35-51. 
Dahlquist, E. (ed.) (2012). Biomass as Energy Source: Resources, Systems and Applications. CRC Press.

Dzikuć, M., \& Łasiński, K. (2014). Technical and Economic Aspects of Biomass Co-Firing in Coal-Fired Boilers. International Journal of Applied Mechanics and Engineering, Volume 19, Issue 4, 849-855.

European Climate Foundation (2010). Biomass for heat and power - opportunity and economics. European Climate Foundation. Retrieved 2/02/2016, from http://www.europeanclimate.org/documents/Biomass_report___Final.pdf

GNESD (2011). Bioenergy: The potential for rural development and poverty alleviation. Global Network on Energy for Sustainable Development (GNESD). Retrieved 2/02/2016, from

http://www.gnesd.org//media/Sites/GNESD/Publication\%20pdfs/Bioenergy_PotentialForDevelopment_SPM.ashx?1 $\underline{\mathrm{a}=\mathrm{da}}$.

IRENA (2012). Biomass for Power Generation. IRENA Working Paper: Renewable Energy Technologies: Cost Analysis Series. Retrieved 2/02/2016, from https://www.irena.org/DocumentDownloads/Publications/RE_Technologies_Cost_AnalysisBIOMASS.pdf

Jansen, R. A. (2012). Second Generation Biofuels and Biomass: Essential Guide for Investors, Scientists and Decision Makers. Wiley.

Karlsson, I., \& Rydén, L. (eds.) (2012). Rural Development and Land Use. The Baltic University Programme, Uppsala University.

Matovic, M. D. (ed.) (2013). Biomass Now - Sustainable Growth and Use. InTech.

National Research Council (2011). Renewable Fuel Standard: Potential Economic and Environmental Effects of U.S. Biofuel Policy. Committee on Economic and Environmental Impacts of Increasing Biofuels Production; National Research Council.

OECD (2012). Linking Renewable Energy to Rural Development. OECD Green Growth Studies, OECD Publishing.

Openshaw, K. (2010). Can Biomass Power Development? International Institute for Environment and Development (IIED). Retrieved 2/02/2016, from http://pubs.iied.org/pdfs/14598IIED.pdf

Riva, G. et. al. (2012). Handbook on Renewable Energy Sources. ENER SUPPLY. Retrieved 2/02/2016, from http://www.ener-supply.eu/downloads/ENER_handbook_en.pdf

Sheelanere, P., \& Kulshreshtha, S. (2013). Sustainable Biofuel Production: Opportunities for Rural Development. International Journal of Environment and Resource (IJER), Volume 2 Issue 1, 1-13.

Shekhar, N. (2010). Popularization of Biomass Briquettes - A means for Sustainable rural van Loo, S., \& Koppejan, J. (eds.) (2008). The Handbook of Biomass Combustion and Cofiring. Earthscan. 
Wichtmann, W., \& Wichmann, S. (2011). Environmental, Social and Economic Aspects of a Sustainable Biomass Production. Journal of Sustainable Energy \& Environment Special Issue, $77-81$. 


\title{
MODULE 3: BIOMASS
}

CHAPTER 3. Social and environmental aspects for rural development.

Subchapter 3.3.: Vision for future. Ideas and new suggestions for future.

\author{
Dr. Zsolt Radics \\ Geolin Co., Hungary
}

Summary: This subchapter offers a brief overview on the vision for the future regarding the use of biomass power. The students can learn about the potentials of biomass resources, the development of combustion technologies and possible technologies of the future. The final part of this subchapter is concerned with the global expansion of biomass power combustion.

\section{Introduction ${ }^{1}$.}

This section offers a brief overview of research and development activities that are ongoing or planned regarding the current state-of-affairs in this field. Areas in which research and development are being performed are: biomass potentials, fuel pre-treatment technologies, combustion, CHP systems, process control and gas clean-up technologies that can cope with difficult-to-burn feedstock, minimize harmful emissions and increase efficiency.

In order to achieve these aims, new and innovative calculation and simulation tools and measurement devices are being used. Another important target of R\&D activities, apart from technological innovation, is the reduction of investment, maintenance and operating costs. However, along with the conditions that can make or break new technologies, the need for research and development also varies per country.

\section{$\underline{\text { Investigation around the potential of biomass resources }}$}

The energy demand has been steadily increasing in recent years worldwide, and this trend is expected to continue. This development has also led to a steady rise in $\mathrm{CO}_{2}$ emissions. To reduce emissions, new solutions are needed. The combustion of solid biomass for heat, power and combined heat and power (CHP) generation is considered to offer one of the highest potentials for renewable energy utilization and $\mathrm{CO}_{2}$ emission reduction in the short to medium term. The European targets, as well as several targets at national levels, and the increasing utilization of solid biomass (especially woody biomass) for energy generation not only in Europe but also worldwide raise several questions concerning the availability of sufficient biomass resources and the reliability of fuel supply to meet these goals. Therefore, the investigation of potentials of biomass resources that are available for thermal utilization becomes more and more relevant. In addition, due to the rising use of solid biomass, efforts must be undertaken to strengthen social and environmental integration along the entire chain from biomass production to provision of energy services to the consumer, because the advantages of the thermal utilization of solid biomass fuels must always be balanced with its disadvantages (e.g. eventual loss of biodiversity, claims on vast areas of land, environmental emissions, hazards and health conditions of workers).

\footnotetext{
${ }^{1}$ The material is widely based on the publications of IEA Bioenergy Agreement, Task 32 'Biomass Combustion and Cofiring’, primarily on the book written by Sjaak van Loo and Jaap Koppejan (2008).

"The European Commission support for the production of this publication does not constitute an endorsement of the contents which reflects the views only of the authors, and the Commission cannot be held responsible for any use which may be made of the information contained therein."
} 


\section{Development of improved combustion technologies}

The development of combustion technologies is still ongoing. The primary aims are to minimize the total costs of heat and/or power production and to maximize safety, ease of operation and efficiency. A future goal is, for instance, to increase the efficiency by higher steam temperatures and pressures and better materials for super heaters. Major goals include the development of new combustion technologies for new biomass fuels (e.g. herbaceous fuels, agricultural waste materials, pellet-fired tiled stoves), and the development of furnaces with a high flexibility regarding biomass fuel quality (multifuel combustion systems).

For medium and large-scale applications, the use of special biomass fuels, such as energy crops, waste wood and agricultural waste materials is of increasing interest. Annually harvested energy crops (like Salix, miscanthus and grasses) in particular will be on the rise in the coming years. Due to their different chemical compositions (as compared to conventional wood fuels), these biomass fuels require special combustion and flue gas cleaning technologies.

Research activities are ongoing in finding better bed materials for fluidized bed combustion plants and concerning changing the combustion environment with additives. The development and/or implementation of innovative process control systems (e.g. Fuzzy Logic, model based control strategies) and innovative sensors for biomass combustion technologies in order to improve and stabilize system operation and to further reduce personnel costs is also a key interest.

\section{$\underline{\text { Gaseous (especially NOx) reduction technologies }}$}

Biomass combustion systems have reached a high technological level, with low emissions and a high operational performance. However, limiting values for gaseous (especially NOx) emissions are constantly being driven down by the authorities, which means that major R\&D efforts will be required in the future to develop even more advanced systems. The overall objective for small, medium and large-scale combustion units is the reduction of gaseous (especially NOx) emissions. This can be done with primary measures or combinations of primary and secondary measures. Generally, the decreasing emission limits for NOx underline the necessity of further developments in this field. These reduction measures further improve the environmental compatibility of thermal biomass utilization, which is one of the most important arguments in the competition with fossil fuel combustion units. The reduction of NOx emissions is of great importance for small-scale combustion units, as they need simple and affordable solutions. Therefore, technologies well proven in medium and large-scale combustion units should be simplified and adapted to small-scale applications. An increased utilization of biomass fuels rich in $\mathrm{N}$ and ash, such as waste wood and energy crops, necessitates the development and market introduction of efficient emission reduction technologies.

$\underline{\text { Ash and aerosol-related problems during biomass combustion including dust (fine particulate) }}$ reduction technologies

Ash-related problems in biomass combustion systems form a hot topic with a high future R\&D demand. These problems cover the areas of particulate formation, deposit formation and corrosion as well as the slagging behaviour of biomass ashes. They are particularly pressing in 
the combustion of non-wood fuels, such as energy crops, straw, grasses, husks, shells or stones as well as waste wood - due to their high concentrations of alkali metals, $\mathrm{S}$ and $\mathrm{Cl}$ as well as volatile heavy metals (especially $\mathrm{Zn}$ and $\mathrm{Pb}$ ) in case of waste wood. They influence the design and process control of furnaces and boilers as well as the optimization of dust precipitation units.

Solid ash and soot particles, emitted from biomass combustion installations, are important sources of fine particulate emissions. However, the limiting values for particulate emissions are driven down by the authorities and therefore primary and secondary measures to reduce particulate emissions have to be developed and optimized.

Consequently, mitigation of fine particulate emissions that result from biomass combustion deserves increased attention from research organizations, manufacturers of boilers and particle removal technologies as well as policy makers. The formation and behaviour of flyashes and aerosols in biomass combustion units has therefore become an important field of research. Equipment manufacturers need to be encouraged to develop novel, low-cost combustion installations and filtration techniques that result in low particulate emissions, even in small-scale applications. Existing and well-proven dust precipitation technologies that are available for medium- and large-scale applications should be simplified and further developed for their application in small-scale units.

Additionally, some attempts to investigate health risks caused by particulate emissions from biomass combustion systems have already been initiated. This research field is of major relevance within the market competition with fossil fuel-based systems and from a human toxicology point of view and will therefore gain increasing relevance in the coming years. However, due to the high complexity of the problems addressed, interdisciplinary research and a close cooperation of technical and medical sciences is needed to succeed.

Another major focus of R\&D activities will be on solving problems concerning deposit formation and corrosion in the heat exchanger sections of large-scale biomass CHP plants. To reduce maintenance and repair costs and to increase the availability of installations, the mechanisms responsible for slagging, fouling and corrosion have to be thoroughly investigated. Further down the road, the search for appropriate primary and secondary measures to prevent deposit formation and corrosion processes as well as to reduce aerosol emissions will also be necessary. In addition to all this, there are also some open questions regarding the environmentally sound utilization of biomass ashes and the development of appropriate treatment technologies for contaminated biomass ashes. In both directions, the search is on for a closed-cycle economy and the minimization of disposal costs.

$\underline{\text { Innovative micro-, small- and medium-scale CHP technologies based on biomass combustion }}$

The demand for combined heat and power production (CHP) from biomass is an important new trend. Large-scale biomass CHP systems based on conventional steam turbine cycles are state-of-the-art. Appropriate CHP technologies for small- and medium-scale combustion systems are under development or market introduction, but still require comprehensive R\&D in order to reach the demonstration stage or to get further optimized.

In the last few years, several new systems such as the ORC process and the Stirling engine technology have emerged for small- and medium-scale CHP production $\left(10-1000 \mathrm{~kW}_{\mathrm{e}}\right)$ based on biomass combustion. The ORC technology for instance, has already been successfully introduced into the market segment aiming at electric capacity ranges between $200 \mathrm{~kW}$ and

"The European Commission support for the production of this publication does not constitute an endorsement of the contents which reflects the views only of the authors, and the Commission cannot be held responsible for any use which may be made of the information contained therein." 
$2000 \mathrm{~kW}$. However, an optimization potential exists regarding the achievement of an increased electrical efficiency, as well as potential concerning cost reduction by modular design.

For the Stirling engine technology, which is already at the demonstration level, further R\&D demand includes fouling and cleaning of high temperature heat exchanger areas, process control and seal development for high pressure systems. Moreover, some promising technologies for micro-scale CHP systems have been identified (e.g. thermoelectric generator, Stirling engine). These technologies have to be further developed in order to reach the demonstration level.

In the field of directly or indirectly fired gas turbines utilizing atmospheric as well as pressurized combustion systems, R\&D activities are also taking place. These CHP solutions are still in an early stage of development. $R \& D$ efforts will concentrate on the further development and optimization of the CHP technologies until they reach the demonstration and dissemination level.

\section{$\underline{\text { Fuel pre-treatment technologies }}$}

There is an increasing demand for solid biomass fuels individually 'tailored' to needs of the respective application process. This is the driving force behind new upgrading methods or technologies that can be applied either during or immediately after field production (e.g. leaching by rainfall or irrigation) or in a preparatory process prior to energetic use (e.g. stationary leaching, use of additives, compaction). Monitoring of production or separation (fractionation) processes should also focus on fuel properties in order to make optimum use of varying or heterogeneous raw materials. Furthermore, fuel quality aspects are becoming a key target in plant breeding and variety/clone selection. Genetic engineering, although still highly controversial, may also open up new chances for yield and quality improvements of biomass fuels.

Short rotation forestry, which has already gained a certain importance in Scandinavia, is of increasing interest as a possible measure for cleaning industrially degraded land from contaminants (bioremediation) as well as for the utilization of set-aside land. It could also raise the economic competitiveness of this type of biomass fuel. If it does, the thermal conversion process needs to be adapted in order to guarantee an ecologically competitive overall energy production process (ash fractionation, efficient dust precipitation). Pelletizing technologies for the production of upgraded biomass fuels must be improved in order to lower costs and enhance fuel quality (proper selection of matrices, testing and evaluation of bioadditives for quality improvement and reduction of operating costs, development and testing of pre-treatment technologies for proper conditioning of the raw material). Moreover, future pellet production will have to cope with raw materials beyond the materials currently most commonly used, i.e. wood shavings and sawdust. Due to strongly increasing pellet markets in Europe and worldwide, the production of pellets from, e.g., woodchips, forestry residues, short rotation coppice and different kinds of herbaceous biomass fuels will increase in the future, which makes respective R\&D activities necessary. Fuel-drying technologies directly coupled to the combustion process in order to achieve high overall energy efficiencies are also an interesting development. 
The application of computational fluid dynamics (CFD) gives a deeper insight into flowrelated processes occurring during thermochemical conversion of solid biomass and therefore is a powerful tool for a quicker, less risky and more reliable development of new technologies. The potential of CFD modelling has increased considerably in the last few years. CFD modelling provides the opportunity to calculate reactive flows including species, temperature and residence time distributions as well as multiphase flows (flue gas as well as fuel and fly-ash particles) in biomass furnaces and boilers. Certain units of biomass conversion systems, such as furnaces, heat exchangers and dust precipitators, can be designed and optimized by means of CFD calculations, which are cheaper and less time-consuming than test runs.

Furthermore, various R\&D projects are ongoing in order to develop CFD models for solid biomass combustion in entrained flows and packed beds. This will further extend the applicability of this powerful tool to pulverized fuel furnaces as well as to the whole conversion process in spreader stoker, underfeed stoker and grate furnaces. Concerning the simulation of thermodynamic and chemical processes, there is an ongoing process of improvement of existing programme codes and databases (e.g. reaction mechanisms). Advanced commercial software is also being developed in the fields of chemical reaction kinetics (e.g. models for NOx and SOx formation) and thermodynamic equilibrium calculation (e.g. modelling of the behaviour of alkali metals, the formation of low melting compounds as well as the behaviour of heavy metals). Such models deepen our understanding of processes with regard to corrosion, formation of sticky deposits and ash/aerosol formation, thus providing the basis for the development of appropriate technological prevention measures.

Commercially available databases contain information on the properties of almost all relevant elements and compounds. However, there are still blanks in the information available on thermodynamic and physical properties of certain elements, compounds and especially multicomponent/multiphase systems, which complicate the simulation of chemical reactions and processes at high temperatures as well as simulations for ash-forming elements and kinetically limited and heterogeneous reaction systems (NOx and SOx formation) in biomass conversion processes. Consequently, further expansion and improvement of basic data and models is necessary.

Moreover, considerable efforts are currently being made to couple the various CFD models developed and to integrate reaction kinetics and equilibrium modelling into CFD simulations, since this approach provides a powerful opportunity for a spatially resolved simulation and visualization of thermochemical biomass conversion processes. CFD simulations will then not only be flow simulations but rather three-dimensional simulations and visualizations of highly complex and linked physical and chemical processes in thermal biomass conversion plants. This is made possible by the continuously increasing computer performance as well as special new simulation techniques, which allow a significant reduction of calculation time and the application of highly complex models as engineering tools.

\section{Global expansion of biomass combustion}

The largest markets for biomass combustion systems currently exist in North America and Europe, totalling about two-thirds of current biomass electricity production. Other important regions in the world are Latin America (particularly Brazil) and Asia. Europe and North America are expected to grow in installed capacity by an average 500 and $250 \mathrm{MW}_{\text {e }}$ per year,

"The European Commission support for the production of this publication does not constitute an endorsement of the contents which reflects the views only of the authors, and the Commission cannot be held responsible for any use which may be made of the information contained therein." 
respectively, but relative growth rates will be highest in Asian and Latin American economies. By 2030 biomass-fuelled electricity production is projected to triple and provide $2 \%$ of world total requirements, $4 \%$ in OECD Europe, as a result of government policies to promote renewables. At least up to 2015-2020, it can be expected that mainstream biomass power technologies will be based on direct combustion and co-combustion using steam cycles. As the global capacity of coal-fired power stations increases further, increased synergy will be found between biomass and coal-based power generation.

The expected growth in biomass combustion systems will take place in dedicated biomass combustion systems using agricultural and process residues, as well as various biomass wastes. On an industrial scale, biomass combustion-based power generation using both grate fired and fluidized bed boilers will continue to dominate the market, as these concepts are already reliable and cost-effective for various fuels and are continuing to improve further. As the financial feasibility of steam cycle-based biomass power systems has a minimum limit of approximately $1 \mathrm{MWe}$, there will be room for innovative but reliable CHP concepts in the medium term, such as organic Rankine cycle (ORC) and Stirling engines, as they are reliable, do not require a pressurized boiler and require little or no user involvement.

For biomass fuels that are clean and brittle, direct co-firing in existing pulverized coal-fired power stations will remain the cheapest option for biomass power. There will also be a place for large-scale fluidized bed gasification systems for biomass that is less brittle and/or contaminated, as this technology can provide a clean gas that can be co-fired in coal-fired and potentially also natural gas-fired power stations. Biomass fuels containing challenging components (e.g. $\mathrm{Cl}$ ) can be burned in a separate boiler, providing steam of medium conditions to even very advanced, ultra-supercritical power plants.

By the possible introduction of the above mentioned methods and by developing the current ones, the expected growth of the installed capacity is shown by Figure 1.

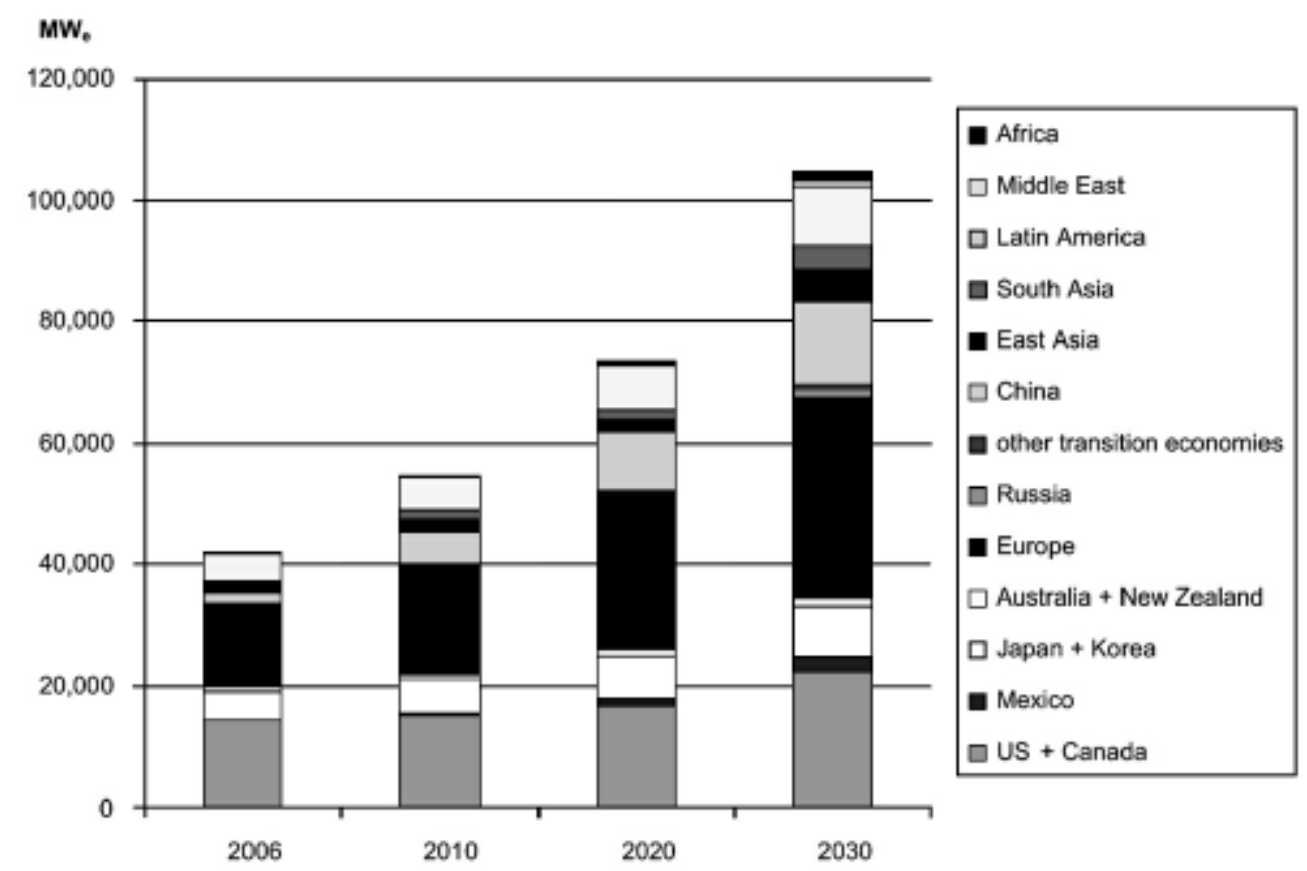

Figure 1. Expected growth in installed capacity (Source: van Loo - Koppejan, 2008)

\section{References}


Breeze, P. (2004). The Future of Global Biomass Power Generation: The technology, economics and impact of biomass power generation. Business Insights.

European Climate Foundation (2010). Biomass for heat and power - opportunity and economics. European Climate Foundation. Retrieved 2/02/2016, from http://www.europeanclimate.org/documents/Biomass_report_-_Final.pdf

European Environment Agency (2006). How much bioenergy can Europe produce without harming the environment? EEA Report. Retrieved 2/02/2016, from http://www.eea.europa.eu/publications/eea_report_2006_7/at_download/file

Hiete, M.; Ludwig, J.; Bidart, C., \& Schultmann. F. (eds.) (2010). Challenges for Sustainable Biomass Utilisation: Proceedings of the Chilean-German Biociclo Workshop (Karlsruhe,

IRENA (2012). Biomass for Power Generation. IRENA Working Paper: Renewable Energy Technologies: Cost Analysis Series. Retrieved 2/02/2016, from https://www.irena.org/DocumentDownloads/Publications/RE_Technologies_Cost_AnalysisBIOMASS.pdf

Mafakheri, F., \& Nasiri, F. (2014). Modeling of biomass-to-energy supply chain operations: Applications, challenges and research directions. Energy Policy, Volume 67, 116-126.

National Research Council (2011). Renewable Fuel Standard: Potential Economic and Environmental Effects of U.S. Biofuel Policy. Committee on Economic and Environmental Impacts of Increasing Biofuels Production; National Research Council.

Odenberger, I., \& Thek, G. (2010). The Pellet Handbook: The Production and Thermal Utilisation of Pellets. Earthscan.

Rosillo-Calle, F.; de Groot, P.; Hemstock, S. L., \& Woods, J. (eds.) (2007). The Biomass Assessment Handbook: Bioenergy for a Sustainable Environment. Earthscan.

Sheelanere, P., \& Kulshreshtha, S. (2013). Sustainable Biofuel Production: Opportunities for Rural Development. International Journal of Environment and Resource (IJER), Volume 2 Issue 1, 1-13.

Sund Energy AS, commissioned by Nordic Energy Research (2010). Mapping Biogas in the Nordic Countries. Nordic Energy Research. Retrieved 2/02/2016, from http://www.nordicenergy.org/wpcontent/uploads/2012/01/mapping biogas_in_the_nordic_countries_-_final1.pdf

van Loo, S., \& Koppejan, J. (eds.) (2008). The Handbook of Biomass Combustion and Cofiring. Earthscan.

Vertès, A. A.; Qureshi, N.; Blaschek, H. P., \& Yukawa, H. (eds.) (2010). Biomass to Biofuels: Strategies for Global Industries. Wiley.

Zhu, J. Y.; Zhang, X., \& Pan, X. (eds.) (2011). Sustainable Production of Fuels, Chemicals, and Fibers from Forest Biomass. Oxford University Press. 


\title{
CASE STUDY DEVELOPMENT
}

\author{
CASE STUDY
}

\section{Felsótárkány Community House Pellet Heating System development}




\section{Introduction}

This article introduces a case study of a wood pellet heated bolier to supply be used in a rural community house in the North Hungarian Region. As the village is situated close to the "Bükk National Park" its touristic function is primary. The building serves needs of local inhabitants and tourists as well.

The building's main characteristics: (Figure 1)

- It has two stories

- The floorspace is about $400 \mathrm{sq}$ m each floor

- The bulding is made up of:

- One big ballroom

- One middel size conference room

- 5 smaller "offices"

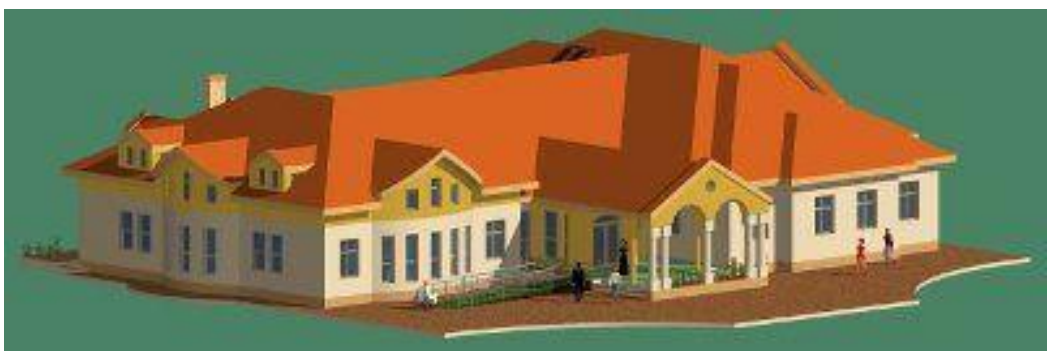

Figure $1 \mathrm{~A}$ visualization of the Community House (Source: www.felsotarkany.hu access 1 May 2016)

\section{Technical aspects of the case study}

\section{LOCATION}

Village: Felsőtárkány (Hungary)

Coordinates: $47^{\circ} 58^{\prime} 23^{\prime \prime}$ North

$20^{\circ} 25^{\prime} 01^{\prime \prime}$ East

Elevation $200 \mathrm{~m}$

The local municipality is aiming to build a new-type building representing its commitment to green sustainable development. At the roof of the building some smaller PV units were 
settled for demonstration purposes, additionally the building is supplied with up-to-date insulation systems.

Biomass fuel is a reliable alternative to fossil fuels. As compressed by-products wood pellets are usually locally available cost-effective fuels. This is a natural raw material as plant lignin holds the pellets together. These are condensed and uniformly sized pieces so it is easily mechanized. Another great advantage is its simplicity with no serious maintenance activities. Such utilities are relatively easy to plan and install. The pellet itself is cheaper and easier to store in small places. Through pellets clean burning of different by-products (residues and sawdust) can be realized. Roughly two types of pellets can be differentiated. On the one hand premium (ash content less than one percent) products are good for industrial utilities. On the other hand standard (ash content between one-two percent) pellets can be used by non-industrial consumers.

Pellet is said to be the lazy men's biomass fuel as it is comfortable to use through mechanized devices of feeding and automatic ash removal as well.

In Felsőtárkány another crucial point is the availability of fuel as well. The Egererdő Corporation has a biomass store in $5 \mathrm{~km}$. The area itself is part of the Bükk Mountain Range so its natural landscape can be characterized by mountains and forests. Forestry is a main economic branch as well.

The villages has approximately 3500 inhabitants. It is one of the touristic centers of the region. Its main sub-branch is eco-tourism. (Figure 2 )

In the layout of the building a centralized hot water heat distribution system is present. There is enough space for the wood pellet boiler and storage silo as well.

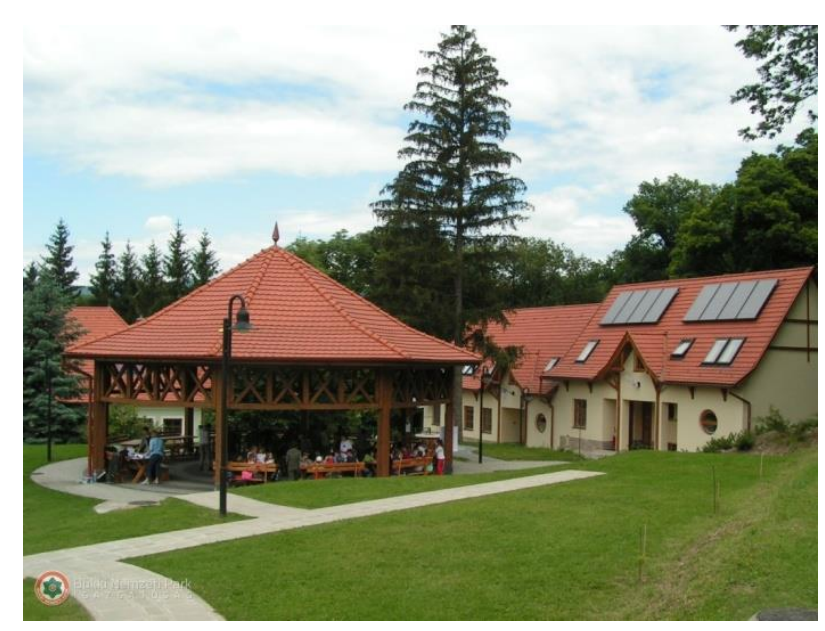

Figure 2 The building of the Bükk National Park in Felsőtárkány - a center of eco-tourism (source: www.bnpi.hu accessed 10 April 2016) 


\section{Calculations and design}

\subsection{Estimation of energy demand}

Firstly it is relevant to estimate the heating energy requirements of the building. (Table 1) In the village traditionally natural gas was the original heating fuel of residential and community buildings as well. Rising prices and uncertainties in natural gas supply made people and municipalities think about changing these systems to more available and local bio-fuels. Beyond covering heating demands domestic hot water needs must be fulfilled as well. The Community House is the venue of community meetings, parties, meeting point for different local clubs. At the same time sometimes big groups of tourists visit it as well. It can be declared as the center of local civil life.

Table1 Estimated daily maximum power and energy demands of the building

\begin{tabular}{|l|l|l|l|l|}
\hline Building & $\begin{array}{l}\text { Ground-space } \\
{[\mathrm{m} 2]}\end{array}$ & $\begin{array}{l}\text { Heated airspace } \\
{[\mathrm{m} 3]}\end{array}$ & $\begin{array}{l}\text { Maximum } \\
\text { demand } \\
{[\mathrm{kW}]}\end{array}$ & $\begin{array}{l}\text { Annual heat } \\
\text { consumption } \\
{[\mathrm{GJ}]}\end{array}$ \\
\hline $\begin{array}{l}\text { Community } \\
\text { House }\end{array}$ & 800 & 2400 & 75 & $184+26$ \\
\hline
\end{tabular}

Source: Own edition according to concerning Hungarian standards (7/2006. (V. 24.) TNM)

Total water demand on the one hand may be determined by a national standard concerning the function of the building and the number of users. (MI-10-158-1:1992 Standard) In this case (Table 2) a Community House should be evaluated as each and every user demands 15 litres of water.

On the other hand domestic hot water consumption can be estimated by the following formula:

$\mathrm{Vm}=0,4 \times \mathrm{V}[\mathrm{m} 3 / \mathrm{d}]$

where " $\mathrm{V}$ " is the total daily water demand of the building.

Through this method byeond an average 1200 litres dail total water consumption about 500 litres of domestic hot water will be needed. 
$\mathrm{Q}(\mathrm{DHW})=1,1 \mathrm{c} \rho \mathrm{V}(\mathrm{tm}-\mathrm{th})[\mathrm{Wh} /$ day $]$

Where

$\mathrm{c}=1,16 \mathrm{Wh} / \mathrm{kg}$ is the specific heat of water,

$\rho=1 \mathrm{~kg} / \mathrm{l}$ is the density of water

$V$ is the amount of daily consumption

th $=10-15^{\circ} \mathrm{C}$ is the temperature of cold water,

$\mathrm{tm}=45-60^{\circ} \mathrm{C}$ is the temperature of hot water

According to this formula the Community House in Felsőtárkány consumes cc. 25-26 GJ a year to produce domestic hot water.

Table 2 Domestic hot water needs of the building (per capita evaluation)

\begin{tabular}{|l|l|l|l|l|}
\hline $\begin{array}{l}\text { No. of users } \\
\text { (daily) }\end{array}$ & $\begin{array}{l}\text { Hot water } \\
\text { demand } \\
\text { (I/cap) }\end{array}$ & $\begin{array}{l}\text { Temperature of } \\
\text { cold water } \\
\text { (Co) }\end{array}$ & $\begin{array}{l}\text { Temperature of } \\
\text { warm water } \\
\text { (Co) }\end{array}$ & $\begin{array}{l}\text { Warm water daily } \\
\text { heat demand } \\
\text { (MJ/day) }\end{array}$ \\
\hline 80 & 15 & 15 & 47 & $\mathbf{8 0}$ \\
\hline
\end{tabular}

Source: The calculation was done according to the MI-10-158-1:1992 Hungarian National Standard

According to the other Hungarian National Standard(7/2006. (V. 24.) TNM Order)9 $\mathrm{kWh} / \mathrm{m} 2 / \mathrm{a}$ is the amount of energy needed for community homes. In this case $800 \times 9=7200 \mathrm{kWh}=26 \mathrm{GJ}$ in a year is the result. The results of the two estimations are similar so our calculations seem to be proper.

\footnotetext{
${ }^{1}$ This data is a rough estimation by local staff.

"The European Commission support for the production of this publication does not constitute an endorsement of the contents which reflects the views only of the authors, and the Commission cannot be held responsible for any use which may be made of the information contained therein."
} 


\subsection{Schematic view of the system}

The system compiled in the Community building should heat the whole building and produce domestic hot water for people using communitiy facilities there. In the centre there is a pellet-heated boiler, it produces heat for the radiators and hot water for plumbing units. The system must contain safety appliances as well: charging unit, valves, pumps, water tank, flue pipe, termostats and an expansion tank at the top of the system. (Figure 3 )

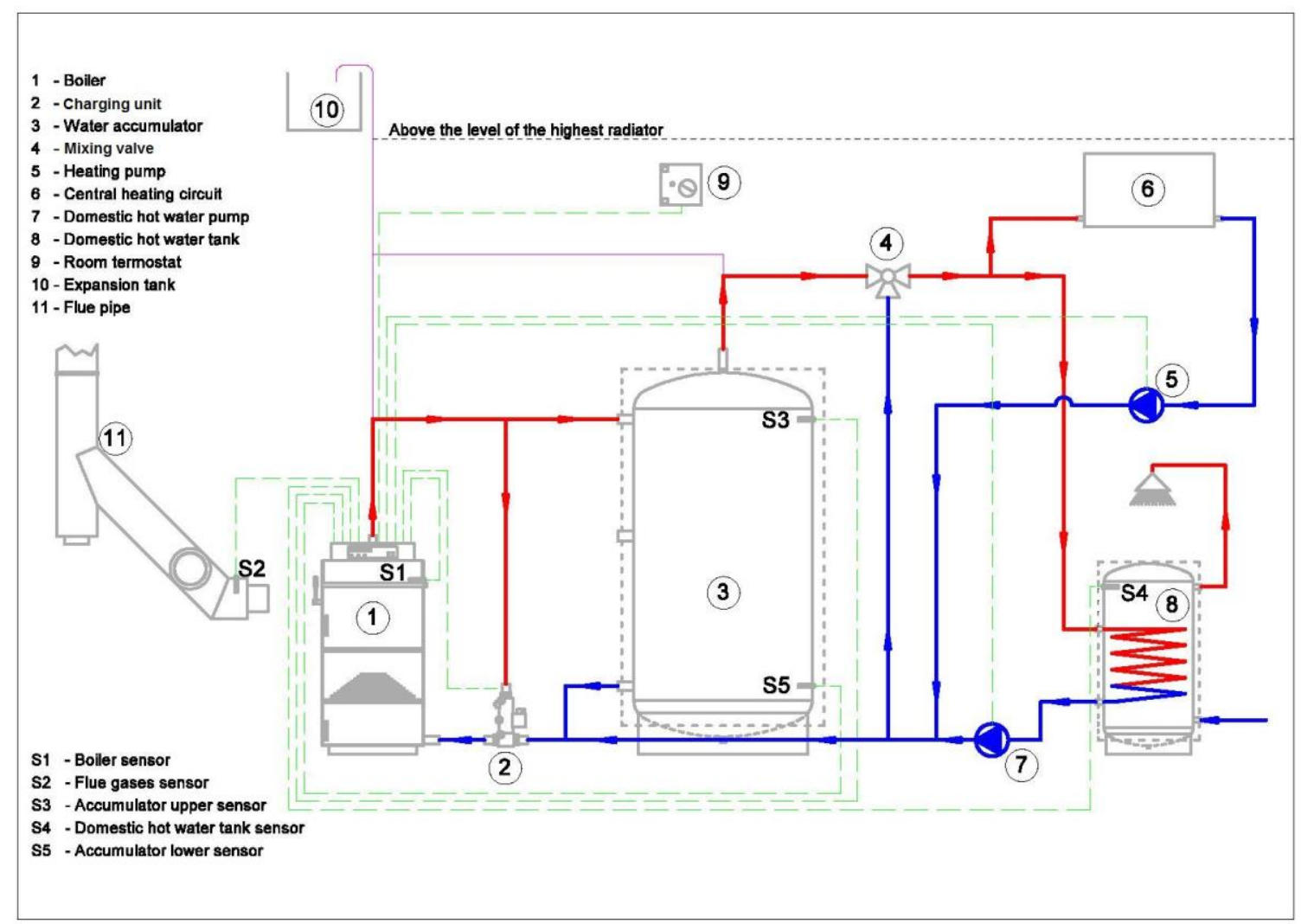

Figure 3 A schematic view of a pellet-boiler supported central heating system (Source: http://www.biomasscenter.org/pdfs/DOER Pellet Guidebook.pdf accessed 30 May 2016)

In the Community House an auger-feed system is used as there is enough place in the boiler's room for pellet storage. The so-called compact pellet boilers integrate in themselves the boiler's body, the pellet container and the feeding auger. Alternatively boilers with separated storage space could be used and the two parts may be placed in separate rooms. (Figure 4) 


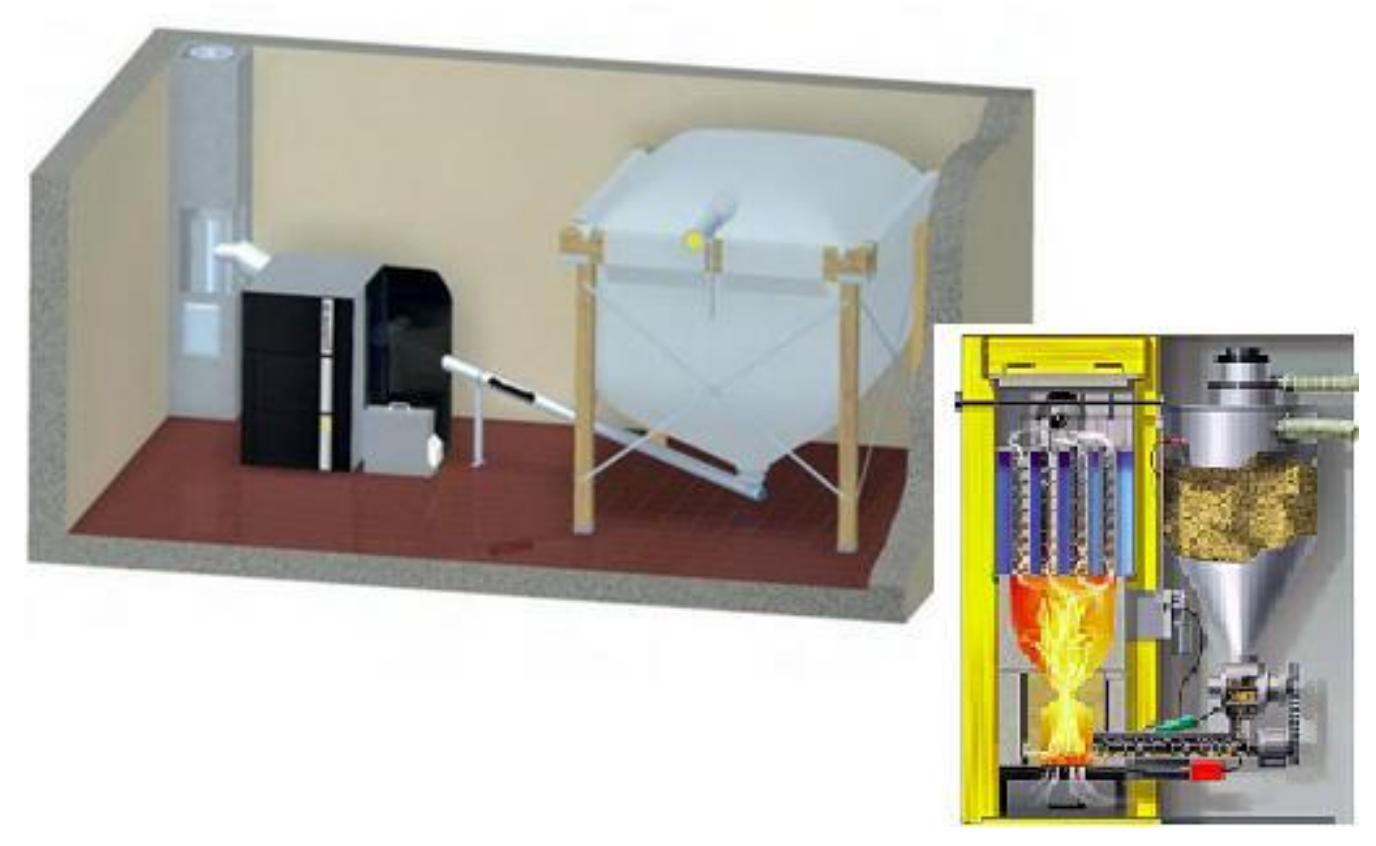

Figure 4 Two types of auger-feed plette boiler systems (Own edition after www.are-ltd.co.uk accessed 1 May 2016)

A PELLMAX $75 \mathrm{~kW}$ automatic pellet boiler is installed in the building. Its efficiency according to literature - can reach $89-92 \%$. Consequently the fuel demand of the annual heat consumption is about $210 \mathrm{GJ}$. (Table 3 )

Table 3 Parameters of the boiler (PELLMAX 75)

\begin{tabular}{|l|l|c|}
\hline $\begin{array}{l}\text { Pellmax( } \\
16-300 \\
\mathrm{~kW})\end{array}$ & Unit & 75 \\
\hline $\begin{array}{l}\text { Heat } \\
\text { exchang } \\
\text { er area }\end{array}$ & $\mathrm{m} 2$ & 9 \\
\hline $\begin{array}{l}\text { Nominal } \\
\text { heat } \\
\text { output }\end{array}$ & $\mathrm{kW}$ & 75 \\
\hline $\begin{array}{l}\text { Heat } \\
\text { efficienc } \\
\mathrm{y}\end{array}$ & $\%$ & $89-92$ \\
\hline
\end{tabular}




\begin{tabular}{|c|c|c|}
\hline $\begin{array}{l}\text { Highest } \\
\text { water } \\
\text { tempera } \\
\text { tue }\end{array}$ & $\mathrm{OC}$ & 95 \\
\hline $\begin{array}{l}\text { Highest } \\
\text { pressure }\end{array}$ & $\mathrm{MPa}$ & 0,2 \\
\hline $\begin{array}{l}\text { Chimney } \\
\text { draught }\end{array}$ & $\mathrm{Pa}$ & 30 \\
\hline $\begin{array}{l}\text { Chimney } \\
\text { diamete } \\
r\end{array}$ & $\mathrm{~cm} 2$ & 625 \\
\hline $\begin{array}{l}\text { Volume } \\
\text { of fire } \\
\text { tank }\end{array}$ & $\mathrm{dm} 3$ & 500 \\
\hline $\begin{array}{l}\text { Water } \\
\text { mass in } \\
\text { boiler }\end{array}$ & $\mathrm{dm} 3$ & 350 \\
\hline $\begin{array}{l}\text { Size of } \\
\text { heated } \\
\text { area }\end{array}$ & $\mathrm{m} 2$ & $750-800$ \\
\hline $\begin{array}{l}\text { Fuel } \\
\text { type }\end{array}$ & \multicolumn{2}{|c|}{$\begin{array}{l}\text { Primarily: DIN+, EN+ quality } \\
\text { pellet. Auxiliary: max } 20 \% \\
\text { water content wood burned } \\
\text { on the supplementary grid }\end{array}$} \\
\hline
\end{tabular}

Source: http://www.kazan-haz.hu/kolton-pellmax accessed 27 May 2016

\subsection{Chimney parameters and pellet storage room planning}

The MSZ 845:2010 Hungarian National Standard regulates chimney applications. For such units at least a $8 \mathrm{~m}$ high and $300 \mathrm{~mm}$ diameter chimney is needed its top must exceed the roof level with at least $400 \mathrm{~mm}$. Fortunately the origional architecture of the building has already contained these technical parameters.

According to literature every $\mathrm{kW}$ heating load needs $0,5-0,9 \mathrm{~m}^{3}$ storage space. Because of security point of view the useable storage space is about $60 \%$ of the total storage space. Accordingly at least $35 \mathrm{~m} 3$ storage room (including emoty space) is needed, the usable space is cc. $23 \mathrm{~m} 3$.

The amount of pellet stored in the room at the same load is $23 \mathrm{~m}^{3} \times 650 \mathrm{~kg} / \mathrm{m}^{3}=14900 \mathrm{~kg}$ (15 t). The size of pellet store room is $35 \mathrm{~m} 3$, as the height is $3 \mathrm{~m}$, the surfacfe of the room is $10,2 \mathrm{~m} 2$.

The stored energy amount is $14900 \mathrm{~kg} \times 5 \mathrm{kWh} / \mathrm{kg}=74500 \mathrm{kWh}$ or $14900 \mathrm{~kg} \times 18 \mathrm{MJ} / \mathrm{kg}=$ $268200 \mathrm{MJ}$

"The European Commission support for the production of this publication does not constitute an endorsement of the contents which reflects the views only of the authors, and the Commission cannot be held responsible for any use which may be made of the information contained therein." 
As it can be seen the theoretically counted size of stored pellet is bigger than that of the annual consumption. Adding the fact that pellets are hygroscopic; in contact with water, damp walls or floors, they swell up and become useless. Damp pellets fall apart and can also block transport lines and damage walls. Consequently we must consider that only in dry places can the material be stored. As the Community House is a newly built building it can be a risk here. It is suggested to use a smaller storage room. The Hungarian distributor offers different fuel storages, the biggest one is $2,8 \mathrm{~m} 3$. Its capacity is able to feed the boiler for about one month. Another spatial factor is crucial for pellet storerooms: these have to have at least one external wall in order to make it easy to refill from the outside. From the figure we may state that the place is appropriate. (Figure 5)

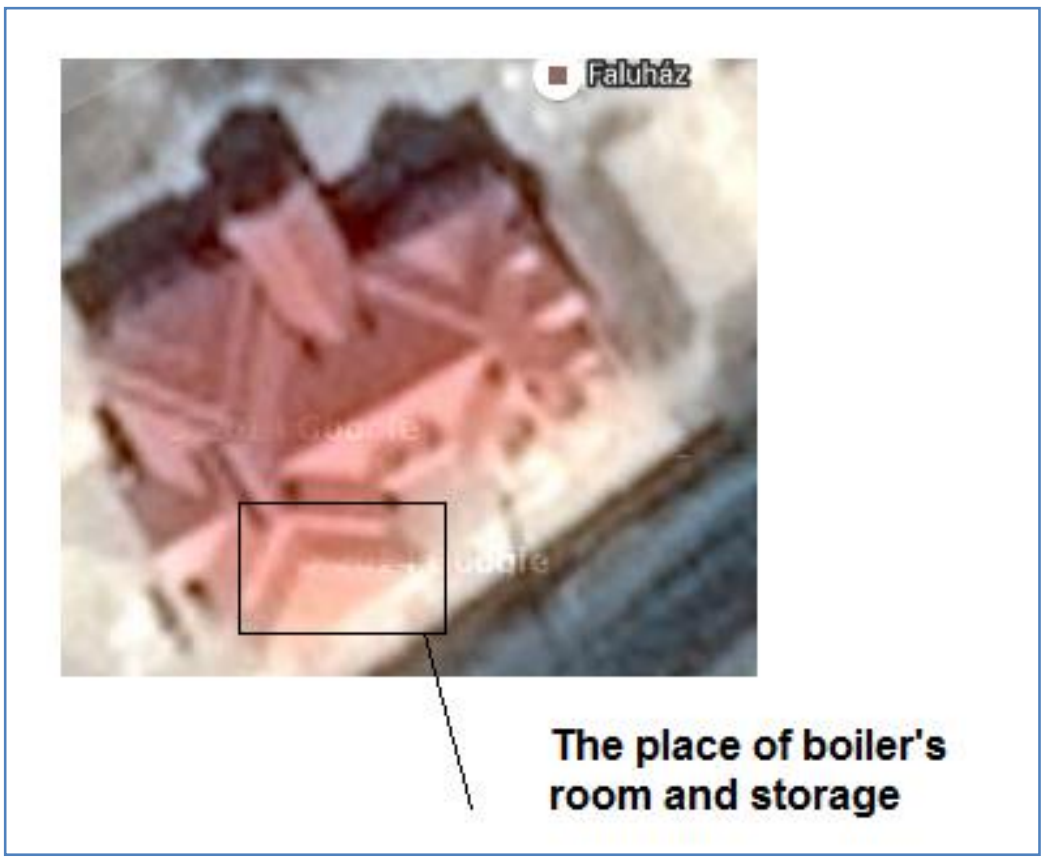

Figure 5 The place of installations in the building (GoogleEarth)

Table 4 O\&M needs of a standard pellet boiler system

\begin{tabular}{|l|l|}
\hline Task & Frequency \\
\hline Ash removal & Weekly \\
\hline Check fuel level & Weekly/Monthly \\
\hline Regular user visual checks & \\
\hline Check for loose moving parts & 3 months \\
\hline
\end{tabular}




\begin{tabular}{|l|l|}
\hline Lubricate moving parts & 3 months \\
\hline Check exhaust system, pumps and fans & 3 months \\
\hline Change cooling oil & 3 months \\
\hline Check monitoring and control system & 3 months \\
\hline Check chimney and flue gas ducting & 3 months \\
\hline $\begin{array}{l}\text { Verify and adjust the system settings, gauges } \\
\text { and meters }\end{array}$ & 3 months \\
\hline $\begin{array}{l}\text { Annual Maintenance by Authorised Service } \\
\text { Agent }\end{array}$ & \\
\hline Clean fuel storage bin and fuel feed system & Annually \\
\hline Clean the heat exchanger \& exhaust pipes & Annually \\
\hline Clean bearings, fans and motors & Annually \\
\hline
\end{tabular}

Source: Carlow Kilkenny Energy Agency (www.ckea.ie accessed 1 May 2016)

Table 5 Installation costs of the system in Felsőtárkány

\begin{tabular}{|l|l|l|l|}
\hline Parts & Size & Type & Price \\
\hline $\begin{array}{l}\text { Pellet boiler (auger- } \\
\text { feed) }\end{array}$ & $75 \mathrm{~kW}$ & PELLMAX 75 & $6800 €$ \\
\hline Charging unit & & Laddomat 21-100 & $400 €$ \\
\hline Water accumulator & 3000 litres & MIBEC & $1800 €$ \\
\hline Mixing valve & & & $200 €$ \\
\hline Heating pump & HB 300 & $800 €$ \\
\hline $\begin{array}{l}\text { Domestichot water } \\
\text { pump }\end{array}$ & & & $300 €$ \\
\hline Domestic hot water & 800 litres & & $1500 €$ \\
\hline
\end{tabular}


of the European Union

\begin{tabular}{|l|l|l|l|}
\hline tank & & & \\
\hline Room termostat & & & $200 €$ \\
\hline Expansion tank & 30 litres & & $200 €$ \\
\hline Flue pipe & & & $250 €$ \\
\hline Sensors (5 pcs) & & & $1000 €$ \\
\hline Pipes and fitment & & LEIER LSK & $1000 €$ \\
\hline Chimney & & & $1500 €$ \\
\hline Storage & 2800 litres & & $900 €$ \\
\hline Installation costs & & & $5000 €$ \\
\hline Total & & & $\mathbf{2 1 8 5 0 €}$ \\
\hline
\end{tabular}

Source: websites of producers and distributors

\subsection{Calculation of annual fuel consumption}

The annual heat consumption of the building (together with domestic hot water consumption) is $210 \mathrm{GJ}$. It must be multiplied by a factor as effectivity of the boiler is about $90 \%$. The final value is cc. $230 \mathrm{GJ}$. Energy content of a kg of wood pellet is approximately 18 MJ, consequently cc. $12800 \mathrm{~kg}$ of wood pellet is needed to cover the consumption. The average market price of a $\mathrm{kg}$ of premium oak and beech pellet ( $6 \mathrm{~mm}$ in diameter) is about $0,3 €$. Consequently the annual fuel costs is cc. $3900 €$. (Table 4 and 5 )

In case of natural gas heating $230 \mathrm{GJ}$ energy could be produced from the burning of cc. 7500 m3 gas (counting with a $90 \%$ gas boiler efficiency). In Hungary the average price of natural gas in 2016 for non-residential users for this amount is cc. $5000 €$.

\section{Financial considerations}


Table 6 Data for the pellet boiler project in Felsőtárkány with investment and operation costs

\begin{tabular}{|l|l|l|l|}
\hline $\begin{array}{l}\text { Percentage of own } \\
\text { funds }\end{array}$ & $10 \%$ & $100 \%$ & $\mathbf{2 5 \%}$ \\
\hline$I_{0}$ (Investment) & $2185 €$ & $21850 €$ & $5463 €$ \\
\hline$M_{t}(\mathrm{O} \& \mathrm{M})$ & $300 € /$ year & $300 € /$ year & $300 € /$ year \\
\hline$F_{t}$ (Fuel expenditures) & $3900 € /$ year & $3900 € /$ year & $3900 € /$ year \\
\hline$E_{t}$ (Energy generation) & $64000 \mathrm{kWh} /$ year & $64000 \mathrm{kWh} /$ year & $64000 \mathrm{kWh} / \mathrm{year}$ \\
\hline$r$ (discount rate) & $5 \%$ & $5 \%$ & $5 \%$ \\
\hline$n$ (investment period) & 20 years & 20 years & 20 years \\
\hline
\end{tabular}

Source: Own edition

The following Table (Table 7) is introducing the differences of the above mentioned three scenarios. The differences in the three Tables are the result of the variant cash-flow in year 0 since here cash flow represents the own funds which needed to be invest. Concerning the fact non-refundable (government/state) subsidies are involved into the analysis, the nonrefundable part is not included where it is present.

Table 7 Financial viability of the project in three scenarios

\begin{tabular}{|c|c|c|c|c|c|c|c|c|c|c|c|c|c|c|c|c|c|c|c|c|c|}
\hline \multicolumn{22}{|c|}{$100 \%$ own resource - Interest rate $5 \% ;$ IRR = no value } \\
\hline Years & 0 & 1 & 2 & 3 & 4 & 5 & 6 & 7 & 8 & 9 & 10 & 11 & 12 & 13 & 14 & 15 & 16 & 17 & 18 & 19 & 20 \\
\hline Disco & - & 76 & 72 & 69 & 65 & 62 & 59 & 56 & 54 & 51 & 49 & 46 & 44 & 42 & 40 & 38 & 36 & 34 & 33 & 31 & 30 \\
\hline nted & 2 & 1, & 5 & 1, & 8, & 6 , & 6 & 8 & 1, & 5, & 1, & 7, & 5 & 4, & 4 & 4, & 6 , & 9 , & 2 & 6 & 1, \\
\hline cash & 1 & 90 & 62 & 07 & 16 & 82 & 97 & 54 & 47 & 68 & 13 & 74 & 46 & 25 & 05 & 81 & 48 & 03 & 41 & 58 & 51 \\
\hline flow & 8 & 48 & 36 & 01 & 2 & 09 & 23 & 51 & 15 & 71 & 06 & 34 & 99 & 71 & 44 & 37 & 92 & 74 & 65 & 72 & 16 \\
\hline & $\begin{array}{l}5 \\
0\end{array}$ & & & & & & & & & & & & & & & & & & & & \\
\hline \multirow{5}{*}{$\begin{array}{l}\text { Cumul } \\
\text { ated }\end{array}$} & - & - & - & - & - & - & - & - & - & - & - & - & - & - & - & - & - & - & - & - & - \\
\hline & 2 & 21 & 20 & 19 & 19 & 18 & 17 & 17 & 16 & 16 & 15 & 15 & 14 & 14 & 13 & 13 & 13 & 12 & 12 & 12 & 11 \\
\hline & 1 & 08 & 36 & 67 & 01 & 38 & 78 & 22 & 67 & 16 & 67 & 20 & 75 & 33 & 93 & 54 & 17 & 83 & 49 & 18 & 88 \\
\hline & 8 & 8, & 2 & 1, & 3 & 6 , & 9, & 0 , & 9, & 3 , & 2 & 4, & 9, & 5, & 1, & 6 , & 9, & 0 , & 8, & 1 & 0 \\
\hline & 5 & 1 & 5 & 4 & 2 & 4 & 4 & 9 & 4 & 7 & 6 & 9 & 4 & 1 & 1 & 3 & 8 & 7 & 3 & 7 & 2 \\
\hline \multicolumn{22}{|c|}{$25 \%$ own resource - Interest rate $5 \% ; \mathrm{IRR}=8 \%$} \\
\hline Years & 0 & 1 & 2 & 3 & 4 & 5 & 6 & 7 & 8 & 9 & 10 & 11 & 12 & 13 & 14 & 15 & 16 & 17 & 18 & 19 & 20 \\
\hline Disco & - & 76 & 72 & 69 & 65 & 62 & 59 & 56 & 54 & 51 & 49 & 46 & 44 & 42 & 40 & 38 & 36 & 34 & 33 & 31 & 30 \\
\hline nted & 5 & 1 & 5, & 1, & 8 & 6 , & 6 & 8, & 1, & 5 , & 1, & 7, & 5 , & 4, & 4, & 4, & 6 , & 9, & 2, & 6 , & 1, \\
\hline cash & 4 & 90 & 62 & 07 & 16 & 82 & 97 & 54 & 47 & 68 & 13 & 74 & 46 & 25 & 05 & 81 & 48 & 03 & 41 & 58 & 51 \\
\hline
\end{tabular}




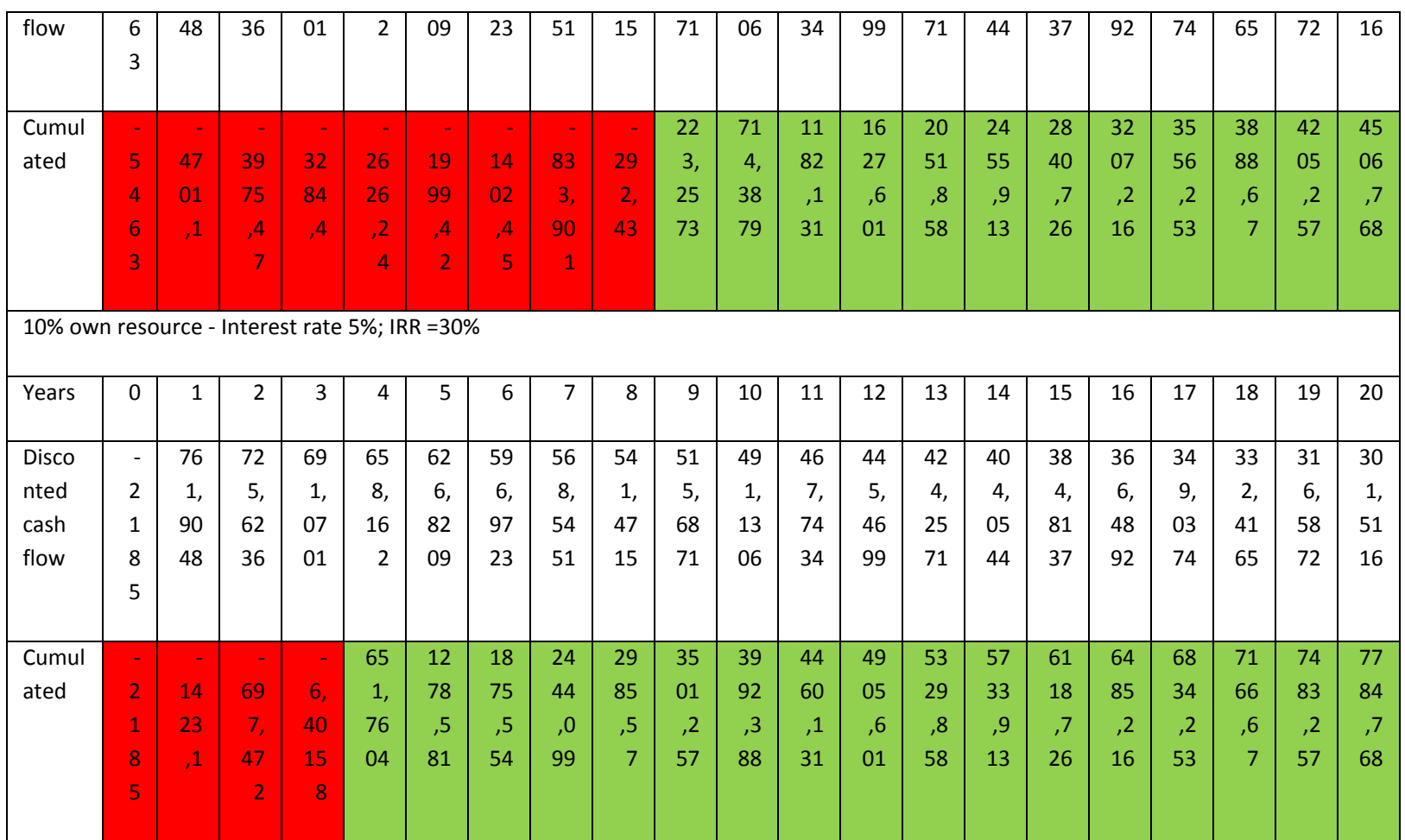

Source: Own edition

In our financial calculations a permanent $800 €$ annual net income was calculated. In our way of thinking the income is coming from the difference between the costs of former natural gas heated system and the recent one. In case of gas and pellet prices permanent levels were calculated as well as in O\&M.

As we may see from the table (Table 7 ) in case of $100 \%$ own financial support the project will never be profitable. In case of $25 \%$ own resource after the eight year the project will produce the invested capita. In the third case (90\%) of EU subsidy - the project will be rentabile in the fourth year. Unfortunately in case of the Hungarian Cohesion Policy it is a rather rare case - only non-profit organizations situated in remote and backward rural areas can hope such support. In case of Felsótárkány the LEADER program supported the project where the support ratio was $90 \%$.

From the table we may see the payback periods in case of the different scenarios. Red colour shows years with deficit, green ones are the profitable periods.

The IRR rate in the first case can't be interpreted - so the investment is not viable in pure market conditions. In case of the two supported scenarios (with $5 \%$ interest rate) the projects will be succesful in financial terms.

After analysing the Table it can be concluded that such investment are very dependent on the origin of the sources. Where the lack of own funds is present with other impedimental factors (like unemployment, aging population etc.), the state, NGOs or the EU need to help

"The European Commission support for the production of this publication does not constitute an endorsement of the contents which reflects the views only of the authors, and the Commission cannot be held responsible for any use which may be made of the information contained therein." 
the local communities and provide them the necessary intellectual and financial aids. The more external source is gained, the more profitable the investment will be in short term, therefore the settlement or the local community is going to energy efficient, sustainable in terms of energy consumption and self-supporting in shorter term. What beneficiaries need to do is to use the sources efficiently, form the view of the people on biomass and other sustainable energy sources and show a good example to others.

\section{Environmental, social and rural impact of the case study development}

\subsection{Environmental impact}

Biomass heating is a renewable energy harvest as $\mathrm{CO} 2$ released by burning (approximately $4000 \mathrm{~kg}$ annually) has come from recent bio-ecological processes. The same amount of it could be consumed by living plants. In the vicinity of the village - as it is a mountain region forest ecosystem is prevailing. Recently wood pellet is coming from the local forestry management company (Egererdő) so biofuel only travels a small distance.

As the pellet boiler is an up-to-date model, it efficiency is very high. Additionally it burns pellet in a clear way so only a negligible amount of ash is produced.

As some particles of the boiler is produced locally, the production cycle of it can be declared relatively short and its environmental impact is small.

In the main environmental dimensions of biomass energy harvest we may say that biodiversity is not affected negatively by this project as only virign forest particles are processed by Egererdő. The company is responsible for sustainable forestry and state regulations prohibit them to cut too many trees. Their task is to prevent invasive plant from spreading and tehir forestry activites can help in it. Soil in the surrounding mountain is brwon forest soil and a planned forestry management made by Egererdő protects soil of high slopes from erosion. As forestry does not use chemicals soil and water habitats (Tárkány Stream) can be free from contamination. The developed forestry management methods of Egererdő help to prevent the over use of forest biomass. The needed amount of harvest residues or stumps are always leaved on site to make available natural nutrients for future tree generations. Illegal and unsustainable logging is penal according to the Hungarian Forest Law.

As pellet is partly made from waste of wood industries, it can help the recycling of byproducts. Egererdő Corporation has a parquet plant in the vicinity its residues are used for pellet production as well. 
Although nowadays pellet used in Felsötárkány is made of wood, but in the future agricultural by-product may be re-used in this way as well. At the same time agricultural land in the village is rare - because of high relief - and it will be used mainly for food crops.

Wood pellet utilization and responsible forest management contribute to the maintenance of local mild climate. Additionally heating 12 tons of wood pellet prevents us from burning 1440 gallons of heating oil or 2000 gallons of propane, $5500 \mathrm{~m} 3$ natural gas, or 4,775 kilowatt hours (kWh) of electricity.

\subsection{Social and rural impact}

Investment in biomass energy technologies benefits to the local macro-economy as some particles of the installed wood pellet boiler are produced in the local industrial park. The final assembly of the boiler is done in Austria, but many Hungarian workforce is used in the value-added chain. Felsőtárkány is a relatively prosperous village in the North Hungarian Region as the local value-added is higher than the average. The level of unemployment is lower than the national average. As the energetic-purpose harvest of biomass is a local tradition, many people work for forestry and related industries. Even the municipality itself is employing local unemployed people as social workers. Their job is to collect forestry byproducts in the surrounding mountains and make them fit for burning in traditional woodfurnaces in other buildings of the municipality. Pellet utilization made local major thinking on developing energy plantations in the vicinity of the village. Wood particles are planned to be processed by a municipality company into wood pellets. In this way the local selfgovernment could be self-sufficient in the field of pellet-heating.

The Community House in the village is the centre of local civil life. It demonstrates green and renewable technologies for local inhabitants and for masses of tourists. With the help of a neighbouring university college a trainig program is working there for local people about renewable energy sources and energy efficiency.

Felsőtárkány is now a beloved village by nearby city citizens (Miskolc and Eger) many middleclass families try to swap here as public services are fully developed. These facilities work even cheaper than their city counterparts because of renewable energy use. We may find here the only PV supported electric car loader in the whole area.

The village inhabitants are really proud of their lifestyle, local NGOs are quite famous in the region. Felsőtárkány in spite of its smallness has an own football team playing in an upper National class.

In the micro region there is a local development NGO (ETFE). Through ETFE meetings surrounding villages can learn from the best practices of Felsőtárkány in the field of renewable energy utilization, rural development and climate protection.

"The European Commission support for the production of this publication does not constitute an endorsement of the contents which reflects the views only of the authors, and the Commission cannot be held responsible for any use which may be made of the information contained therein." 


\section{Conclusions}

The village of Felsőtárkány is situated in the North Hungarian Region in the Bükk Mountains. Its Community House was built to be a representative place for local people. The building is an energy-efficient one and symbolizes renewable energy penetration into the Hungarian countryside.

Wood pellet can be declared a local product that's why the municipality created a wood pellet boiler heated central heating system in the building. We saw that because of the function of the House a relatively high amount of energy is used for domestic hot water making. We went through technical steps of heat demand estimation. Although pellet boiler is the heart of it, central heating system is a complex one and other particles must be integrated. In determinig these details, beyond professional literature different national architectural standards had to be utilized. For technical details and price calculations websites of different producers were visited.

From the financial chapter we saw that unfortunately for rural Hungarian municipalities such investments are relatively hard to make because of the lack of own money. Only different EU supported programmes can help achieving these aims. In case of Felsőtárkány a $75 \%$ of EU support makes the project viable. Fortunately the LEADER program in the former period contained enough sources to support effectively these issues.

This biomass project can be declared $\mathrm{CO} 2$ independent and at the same time helps to save local natural environment.

Socially the building represents not only a sustainable construction, but a socially constructed focal point of a proud and environment-friendly local community.

\section{References}

[1] 7/2006. (V. 24.) TNM

[2] MI-10-158-1:1992 Standard

[3] www.are-Itd.co.uk accessed 1 May 2016

[4] www.biomasscenter.org/pdfs/DOER_Pellet_Guidebook.pdf accessed 30 May 2016

[5] www.bnpi.hu accessed 10 April 2016

[6] www.ckea.ie accessed 1 May 2016

[7] www.felsotarkany.hu accessed 1 May 2016

[8] www.kazan-haz.hu/kolton-pellmax accessed 27 May 2016

"The European Commission support for the production of this publication does not constitute an endorsement of the contents which reflects the views only of the authors, and the Commission cannot be held responsible for any use which may be made of the information contained therein." 


\section{MODULE 3: BIOMASS ENERGY}

CHAPTER 5. Proposed case studies

Subchapter 5.1 - Case Study 1

Dr. Zsolt Radics, Dr. Csaba Patkós

GEOLIN 


\section{CASE STUDY 1}

A municipality, Kengyel in the North Great Plain Region, Hungary is planning to replace recent heating system of its Mayor's office building. It was energetically optimized recently (insulation, up-todate windows and doors, technical services systems). The building has a gas boiler

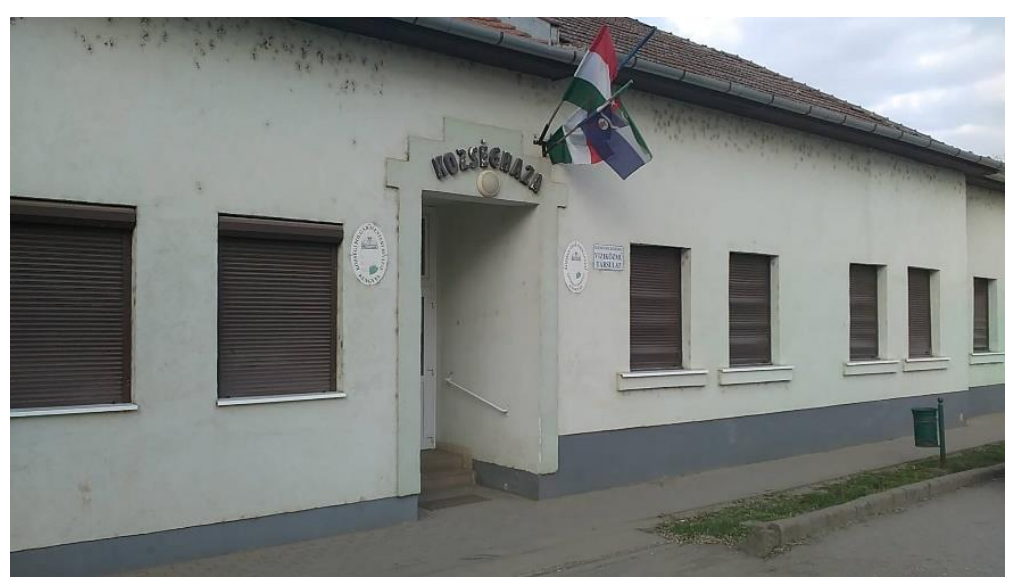
for heating (space heating and hot water) but as gas prices rise, a cheaper fuel should be invented. The village has 3500 inhabitants and is located on the Great Hungarian Plain in the middle of a good-quality arable land zone. The main crops are wheat, barley and corn.

\subsection{Input data}

\section{LOCATION}

Village: Kengyel (Hungary)

Coordinates: $47^{\circ} 05^{\prime} 31^{\prime \prime}$ North

$20^{\circ} 20^{\prime} 24^{\prime \prime}$ East

The building is situated in the centre of the village, although there is enough place around it for biomass storage.

\section{ENERGY NEEDS}

Heated area: $440 \mathrm{~m} 2$

Number of levels: 1

Heated airspace: $1280 \mathrm{~m} 3$

Location: freestanding building

Wall thickness and material: $35-45 \mathrm{~cm}$, mixed brick and adobe

Roof type: pitched without insulation

Doors and windows: wood with one layer of glass

"The European Commission support for the production of this publication does not constitute an endorsement of the contents which reflects the views only of the authors, and the Commission cannot be held responsible for any use which may be made of the information contained therein." 
Heating type: central heating with radiators

Annual amount of gas used: $14.000 \mathrm{~m} 3$

Annual cost of heating (gas): $6000 €$

Production of domestic hot water: gas

Demand for domestic hot water: 16 persons

\subsection{Considerations for the study}

- Although local farmers use wheat and barley straw for animal husbandry, a significant amount of it is still available

- The price of straw is approximately $50 € / \mathrm{t}$ (market price - in case of own arable lands costs are $40 \%$ lower)

- A straw bale heating furnace is preferred by the municipality

- Permanent stoker staff is available to support the system

- The cost of the installation shall be calculated by the student

- For the economic analysis, a price of installation $7000 €$ and the cost of energy consumption of $0,19 € / \mathrm{kWh}$ should be considered

- $2,5 \mathrm{~kg}$ straw is equal with $1 \mathrm{~m} 3$ of gas in energy content

- Pay attention to the social and environmental consequences of the project as well 


\section{MODULE 3: BIOMASS ENERGY}

CHAPTER 5. Proposed case studies

Subchapter 5.2 - Case Study 2

Dr. Zsolt Radics, Dr. Csaba Patkós

GEOLIN 


\section{CASE STUDY 2}

In the vicinity of the village Zagyvarékas, Hungary there's floodplain poplar forest owned by the municipality. The local self-government wants to replace the former mixed fuel furnace with an automatic controlled woodchip boiler in the school building. A wood disintegrator is available locally, but a local storage is needed to be built. The village is in the North Great Plain Region in a backward microregion so EU aid is available for RES development. In relation with the project one roofed storage $(150 \mathrm{~m} 2)$ should be built. Two full-time employees can be employed in connection with the operation of the project.

\subsection{Input data}

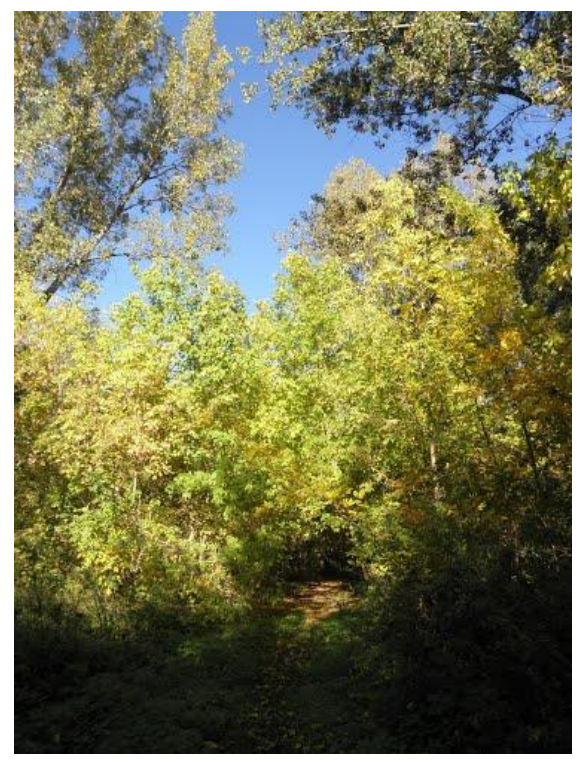

\section{$\underline{\text { LOCATION }}$}

Village: Zagyvarékas

Coordinates: $47^{\circ} 16 \mathrm{~N}$

$20^{\circ} 08^{\prime} \mathrm{E}$

\section{ENERGY NEEDS}

The net annual energy consumption of the school building is $280000 \mathrm{kWh} 90 \%$ of it is used for heating.

The remaining $10 \%$ is for lighting and domestic hot water. It is consumed in the form of electricity.

\subsection{Considerations for the study}

- Consider the social aspects and rural development impact of the project

- The cost of the installation shall be calculated by the student based on the ratios indicated in the course syllabus

- The EU co-financed Hungarian "KEHOP" program supports the energetic modernization of public buildings

- In Zagyvarékas there is a possibility to employ unemployed people by the municipality through a government-supported social-employment grant system 
- Recently the poplar wood is not enough to provide supply in $100 \%$, but in the vicinity of the villages there are uncultivated areas partly owned by the municipality suitable for energy plantations 


\section{MODULE 3: BIOMASS ENERGY}

CHAPTER 5. Proposed case studies

Subchapter 5.3 - Case Study 3

Dr. Zsolt Radics, Dr. Csaba Patkós

GEOLIN 


\section{CASE STUDY 3}

In Jászapáti, Jász-NagykunSzolnok County, North Great Plain Region, Hungary (8500 inhabitants) a agricultural local company (Jászapáti $2000 \mathrm{Mg}$. Zrt) has built a biogas power station. As the corporation's main activity is animal husbandry it is aiming to utilize by-products of the livestock farm and organic waste coming from the vicinity (dairy waste, sewage sludge).

The power station generates

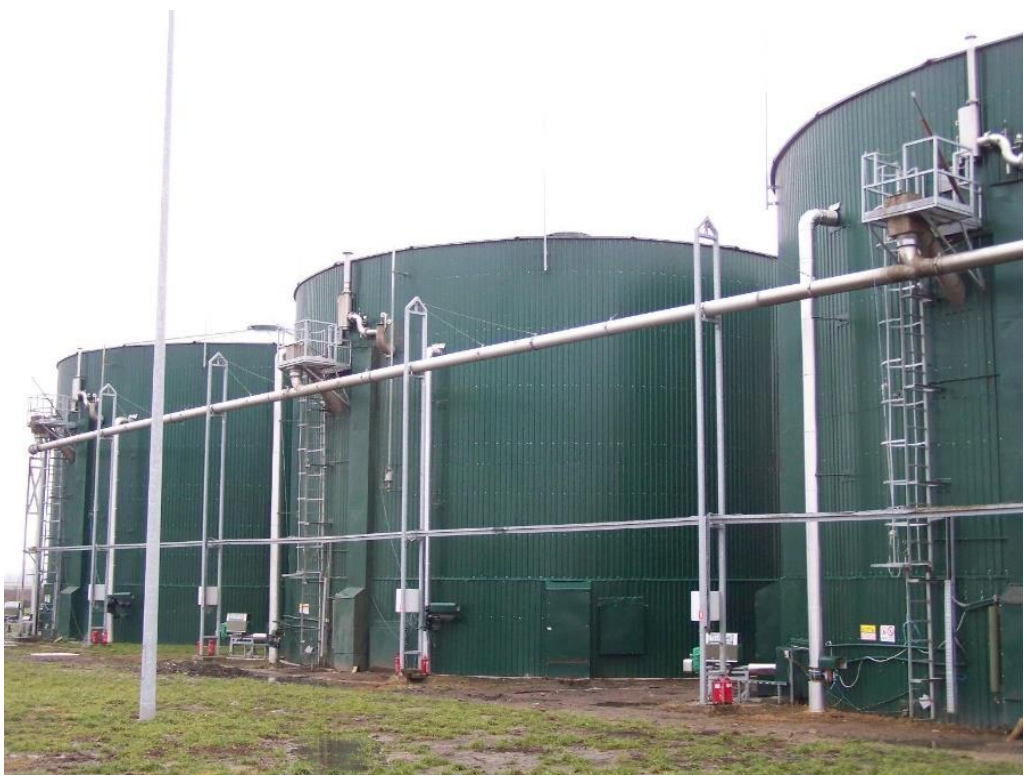
electricity - it is uploaded to the national grid - equal with the consumption of 2400 households annually. Nowadays the exploit of the station is about $70 \%$, but it is aimed to increase. Remaining slurry is used as organic fertilizer in close arable lands.

\subsection{Input data}

\section{$\underline{\text { LOCATION }}$}

Address: Jászapáti 0145/5 hrsz

Town: Jászapáti

Coordinates: $47^{\circ} 30^{\prime} 49^{\prime \prime}$ North

$20^{\circ} 08^{\prime} 25^{\prime \prime}$ East

\section{ENERGY NEEDS}

The power station uses $74760 \mathrm{t}$ /year residuum in it 4 fermentors.

It produces $300.000 \mathrm{kWh} /$ electricity in every months through burning biogas in motors Heat is used only in site 
The composition of raw material in a year:

\begin{tabular}{|l|c|}
\hline Pig liquid manure & $30000 \mathrm{t}$ \\
\hline Pig manure & $2800 \mathrm{t}$ \\
\hline Cow liquid manure & $5000 \mathrm{t}$ \\
\hline Cow manure & $4000 \mathrm{t}$ \\
\hline Other manure & $6000 \mathrm{t}$ \\
\hline Industrial organic waste & $11010 \mathrm{t}$ \\
\hline Tankage & $6800 \mathrm{t}$ \\
\hline Agricultural waste & $2950 \mathrm{t}$ \\
\hline Commercial waste & $1200 \mathrm{t}$ \\
\hline Communal waste & $5000 \mathrm{t}$ \\
\hline
\end{tabular}

\subsection{Considerations for the study}

- Heat utilization in the broader surrounding would make the plant more economic - the town center is cc. $3 \mathrm{~km}$ far from it

- Public buildings are in the center of the town

- There is an industrial park $5 \mathrm{~km}$ far from the biogas station - its buildings are heated by natural gas - totally $38059 \mathrm{~m} 2$ area is going to be built here

- Plan a draft to use biogas generated hot water to supply heat demands

- As the town is located in a EU cohesion region, there are many possibilities to get financial support for such projects

- The cost of the installation shall be calculated by the student based on the ratios indicated in the course syllabus 


\section{MODULE 3: BIOMASS ENERGY}

CHAPTER 5. Proposed case studies

Subchapter 5.4 - Case Study 4

Dr. Zsolt Radics, Dr. Csaba Patkós

GEOLIN 


\section{CASE STUDY 4}

Egerszalók is a village (approximately 2000 inhabitants) is in the middle of a wine-growing area in the North Hungarian Region. It is famous for its thermal spa and geothermal energy utilization although its biomass potential is not used. The village has many vineyards as often vine-branch is a waste. To the north deciduous forests can be found so forestry lopping is available as well. As tourism is the main economic

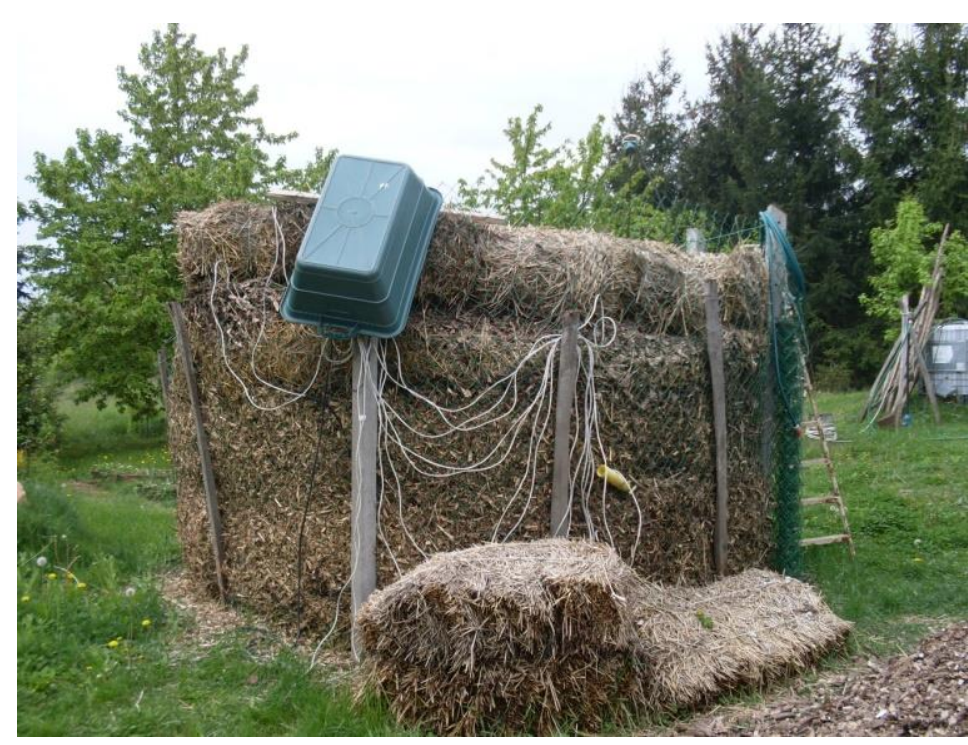
branch of the community biomass burning is not allowed in order to avoid air pollution. A young engineer is experimenting with a so-called compost boiler to heat a greenhouse. A compost dump with a diameter of $3 \mathrm{~m}$ is able to heat a small building for 6 months through a worm.

\subsection{Input data}

\section{LOCATION}

Village: Egerszalók

Coordinates: $47^{\circ} 52^{\prime} 12^{\prime \prime}$ North

$20^{\circ} 19^{\prime} 26^{\prime \prime}$ East

\section{ENERGY NEEDS}

A $100 \mathrm{~m} 2$ family house in standard energy class should be heated by the application

The annual energy consumption is about $8500 \mathrm{Kwh}$

An average temperature of $20^{\circ} \mathrm{C}$ should be maintained in the house

Permanently $30-35^{\circ}$ temperature of the heating agent water is needed inside the worm

The integration of a circulation pump is offered into the worm - it needs electricity 


\subsection{Considerations for the study}

- Raw materials for the compost (plants and animal waste) can be found in the village

- Plant particles must be spalled in order to make them decayed

- The compost should contain livestock and vegetable materials

- A proper aeration is needed by the compost dump

- The cost of the installation shall be calculated by the student based on the ratios indicated in the course syllabus

- Used compost (after 5-6 months) can be utilized as natural fertilizer 


\section{MODULE 3: BIOMASS ENERGY}

CHAPTER 5. Proposed case studies

Subchapter 5.5 - Case Study 5

Dr. Zsolt Radics, Dr. Csaba Patkós

GEOLIN 


\section{CASE STUDY 5}

Halmaj is a small village (1800 inhabitants) in the North Hungarian Region. One of its main demographic characteristic is the high ratio of Roma population whose educational level is far below the average and unemployment is extremely high among them $(50 \%)$. A project is aiming to involve 30 people in bio-briquette production. The raw

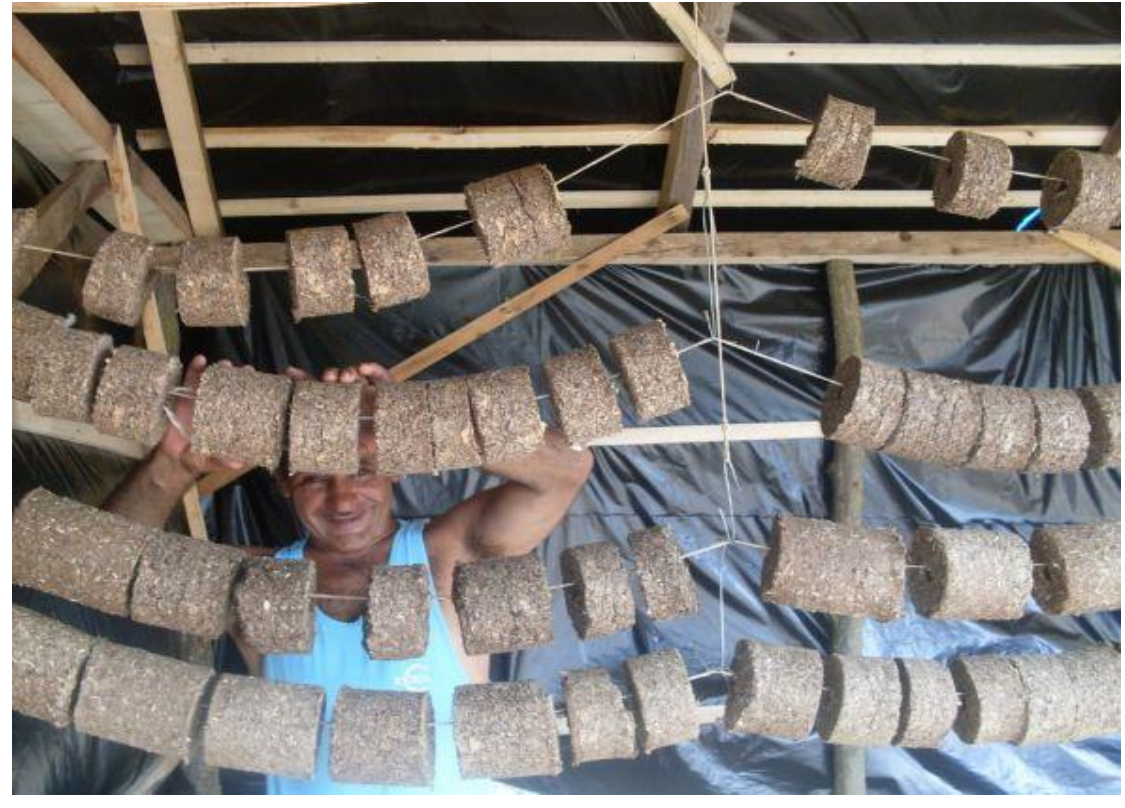
material should be collected from agricultural residues of local farmers and of municipalityowned lands. There are state and EU-financed financial aid programmes to support disadvantageous Roma people to be self-supporting.

\subsection{Input data}

\section{LOCATION}

Village: Halmaj

Coordinates: $48^{\circ} 14^{\prime} 48^{\prime \prime}$ North

$21^{\circ} 00^{\prime} 07^{\prime}$ ' East

\section{ENERGY NEEDS}

At the first stage the aim is to satisfy the fuel needs of 100 families. They are living in outof-date family houses without any insulation systems. The annual heating energy need of each is about $280000 \mathrm{Kwh}$.

\subsection{Considerations for the study}

- Raw material is provided by local farmers and the municipality with no cost, only collecting is a task.

- Material used for briquetting needs a proper preparation.

- Finished briquettes should be stored in a dry place. 
- A briquette compressor can be procured from $8000 €$ (a capacity of $30-100 \mathrm{~kg} / \mathrm{h}$ ).

- Labour requirements can be covered by the social employment of local Roma adults they are totally paid by the state.

- Energy content of briquettes should be counted according to the course syllabus.

- The cost of the installation shall be calculated by the student based on the ratios indicated in the course syllabus. 


\section{MODULE 3: BIOMASS ENERGY}

CHAPTER 5. Proposed case studies

Subchapter 5.6 - Case Study 6

Dr. Zsolt Radics, Dr. Csaba Patkós

GEOLIN 


\section{CASE STUDY 6}

Hangony is a small village in North Hungary (Borsod-Abaúj-Zemplén County) with 1600 inhabitants. Because of the closing of coal mines in Hungary, old coal-fed furnaces have to be replaced by modern biomass-fed ones in buildings of public institutions. Biomass is available in the village (pruned branches from gardens) and the municipality located a dappled willow energy-plantation as well to feed her heating systems. As in the village a lot of under-educated unemployed people

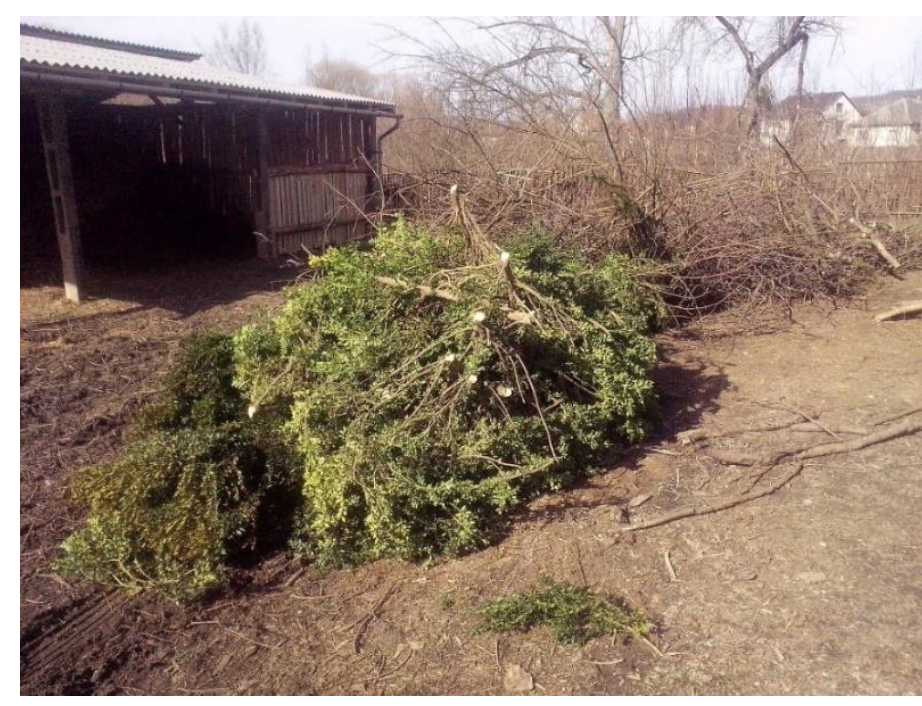
can be found, biomass harvest is an excellent way of job creation.

The village is located in a multiply disadvantaged micro region and there are many external financial aid possibilities for different development purposes. (Széchenyi 2020 Programme).

\subsection{Input data}

\section{LOCATION}

Village: Hangony

Coordinates: $48^{\circ} 13^{\prime} 31^{\prime \prime}$ North

$20^{\circ} 11^{\prime} 59^{\prime \prime}$ East

\section{ENERGY NEEDS}

Three public institutions should be heated by separate biomass furnaces additionally domestic hot water needs should be satisfied for 140 pupils and 15 teachers.

\begin{tabular}{|l|l|l|}
\hline Building & Area & Furnace output \\
\hline School & $3000 \mathrm{~m} 2$ & $600 \mathrm{KW}$ \\
\hline Kindergarten & $450 \mathrm{~m} 2$ & $75 \mathrm{KW}$ \\
\hline $\begin{array}{l}\text { Day-care centre with social } \\
\text { kitchen }\end{array}$ & $340 \mathrm{~m} 2$ & $80 \mathrm{KW}$ \\
\hline
\end{tabular}




\subsection{Considerations for the study}

- Furnaces should be fed by biomass chips - a shredder is available at the municipality.

- $5500 \mathrm{~m} 3$ storage building is needed as well.

- Each furnaces work separately and except the $80 \mathrm{KW}$ one have to be fed manually.

- The cost of the installation shall be calculated by the student based on the ratios indicated in the course syllabus.

- The local forestry management state-owned enterprise (Egererdö Zrt.) support the village with junked Christmas Trees

- The local municipality is in a hard financial situation so any cuts in expenses is inevitable

- There are national and EU financial aid possibilities for small municipalities to modernize public buildings energetically 


\title{
MODULE 3: BIOMASS ENERGY \\ CHAPTER 5. Proposed case studies
}

Subchapter 5.7 - Case Study 7

Dr. Zsolt Radics, Dr. Csaba Patkós

\author{
GEOLIN
}




\section{CASE STUDY 7}

The area of the „BÜKK MAK LEADER Local Action Group" is located in the North Hungarian Region. Its integrated rural development plan contains the vision of a micro-regional integrated electric network (MIKROVIRKA). According to plans each and every village will join the network as an electricity producer as a local small power station is going to be operated. One type of these micro-stations will be vegetable oil fed ones. Farmers and municipalities having proper land for vegetable oil production are

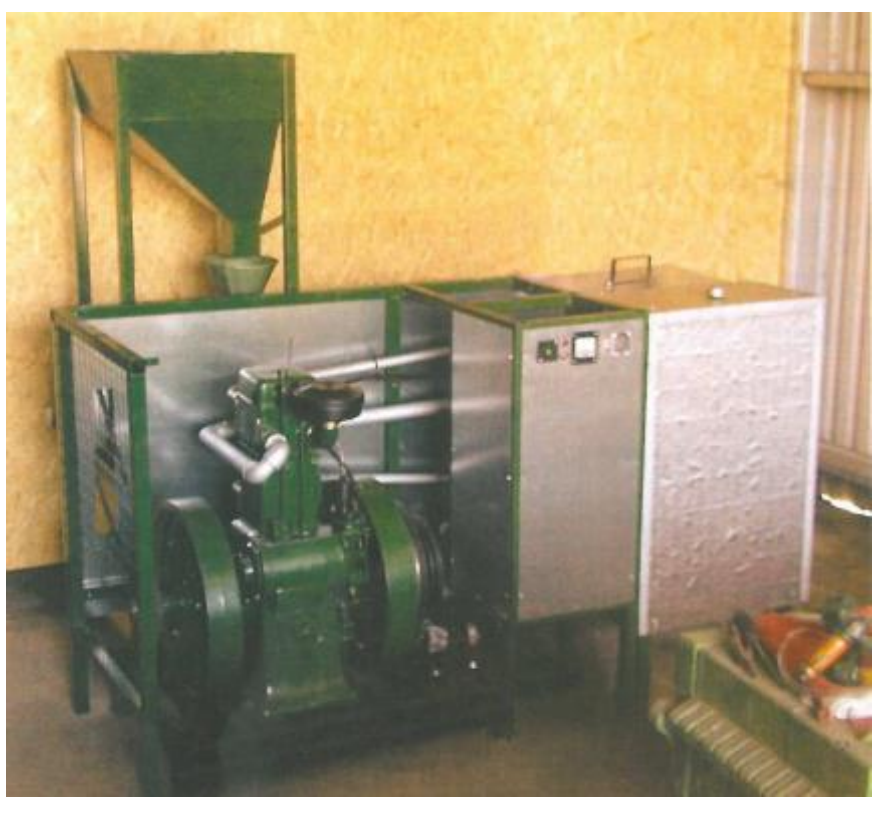
able to operate such facilities. Coats of (e.g. sunflower) seeds can be used for pellet-making as well. The constructions consists of a special diesel engine and a generator producing electricity.

\subsection{Input data}

\section{$\underline{\text { LOCATION }}$}

Village: Bükkaranyos

Coordinates: $47^{\circ} 59^{\prime} 08^{\prime \prime}$ North

$20^{\circ} 46^{\prime} 50^{\prime \prime}$ East

\section{ENERGY NEEDS}

A capacity of 7,5-15 kW micro power station should be established in the village

The engine will be fed by raw vegetable oil (e.g. sunflower)

For the installation a slow-speed engine, a chassis, a cooling-water tank, an oil tank, an AC synch generator, a starting module, an accumulator charger DC generator should be integrated

$1 \mathrm{kWh}$ of electricity can be produced from $268 \mathrm{~g}$ of vegetable oil 


\begin{tabular}{|c|c|c|}
\hline Energy supply & Consumption & Size \\
\hline $\begin{array}{l}3 \mathrm{~kW} \text { AC } 220 \mathrm{~V} 1 \text { period, } \\
1 \mathrm{~kW} \text { DC } 12 / 24 \mathrm{~V} 6 \text { (with } \\
\text { heater } 8 \text { ) } \mathrm{kW} \text { heat output, } \\
80^{\circ} \mathrm{C}\end{array}$ & 0,5-1 litres/hour & $\begin{array}{l}\text { Base: } 1,1 \mathrm{~m} \times 1,0 \mathrm{~m} \\
\text { Height: } 1,5 \mathrm{~m}\end{array}$ \\
\hline $\begin{array}{l}5 \mathrm{~kW} \text { AC } 220 \mathrm{~V} 1 \text { period, } \\
\text { welding generator } 160 \mathrm{~A} \\
12 \text { (with heater } 15 \text { ) } \mathrm{kW} \\
\text { heat output, } 80^{\circ} \mathrm{C}\end{array}$ & 1-2 litres/hour & $\begin{array}{l}\text { Base: } 1,2 \mathrm{~m} \times 1,0 \mathrm{~m} \\
\text { Height: } 1,5 \mathrm{~m}\end{array}$ \\
\hline $\begin{array}{l}7,5 \mathrm{~kW} \text { AC } 380 \mathrm{~V} 3 \\
\text { periods, } 1 \mathrm{~kW} \text { DC } 12 / 24 \mathrm{~V} \\
12 \text { (with heater } 18 \text { ) } \mathrm{kW} \\
\text { heat output, } 80^{\circ} \mathrm{C}\end{array}$ & 1-2 litres/hour & $\begin{array}{l}\text { Base: } 1,4 \mathrm{~m} \times 1,0 \mathrm{~m} \\
\text { Height: } 1,7 \mathrm{~m}\end{array}$ \\
\hline $\begin{array}{l}15 \mathrm{~kW} \text { AC } 380 \mathrm{~V} 3 \\
\text { periods, } 1 \mathrm{~kW} \text { DC } 12 / 24 \mathrm{~V} \\
22,5 \text { (with heater } 35) \mathrm{kW} \\
\text { heat output, } 80^{\circ} \mathrm{C}\end{array}$ & 2-4 litres/hour & $\begin{array}{l}\text { Base: } 1,5 \mathrm{~m} \times 1,2 \mathrm{~m} \\
\text { Height: } 1,8 \mathrm{~m}\end{array}$ \\
\hline
\end{tabular}

\subsection{Considerations for the study}

- A slow-speed diesel engine should be installed (a John Deer „Wankelmotor” can function with pure vegetable oil)

- Through an inverter the application can be integrated to the national grid

- The cost of the installation shall be calculated by the student based on the ratios indicated in the course syllabus

- From $1 \mathrm{t}$ of seed by extruding $300 \mathrm{~kg}$ oil and $700 \mathrm{~kg}$ pellet may be produced

- Costs: price of the seed an of electricity $(1 \mathrm{t}$ seed $-100 \mathrm{kWh}-17 €)$

- System is more economical if produced heat is used locally 


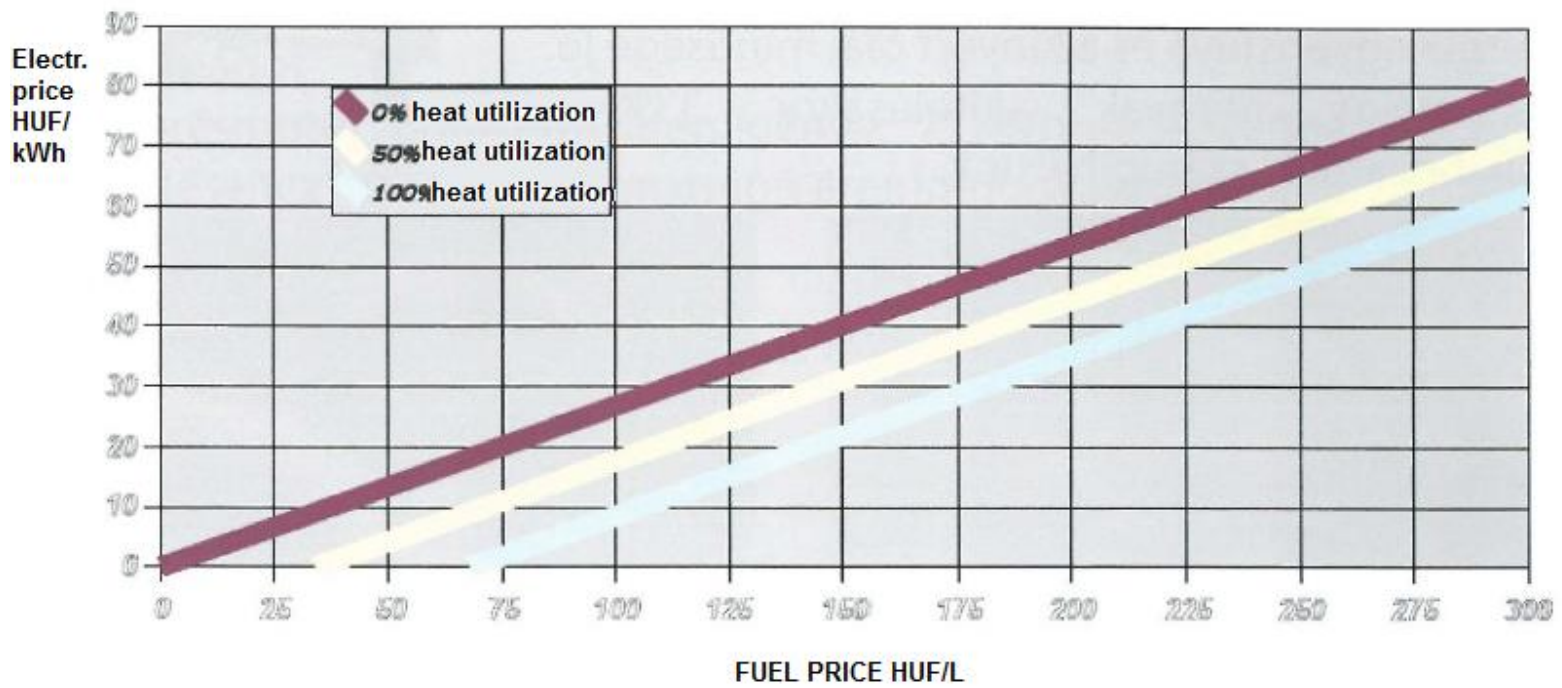

Oil can be produced locally by cold extruding, from seeds a $33 \%$ oil ratio can be produced

A $300 \mathrm{HUF} / €$ exchange rate should be calculated 


\section{MODULE 3: BIOMASS ENERGY}

CHAPTER 5. Proposed case studies

Subchapter 5.8 - Case Study 8

Dr. Zsolt Radics, Dr. Csaba Patkós

GEOLIN 


\section{CASE STUDY 8}

Bercel is a small village (2000 inhabitants) in the North Hungarian Region (Nógrád County). Because of high natural gas prices the local municipality uses biomass heating (woodchips) in four places: kindergarten, school, municipality bureau and heating centre (this latter supplies the local medical centre, pharmacy, village nursing home and emergency centre).

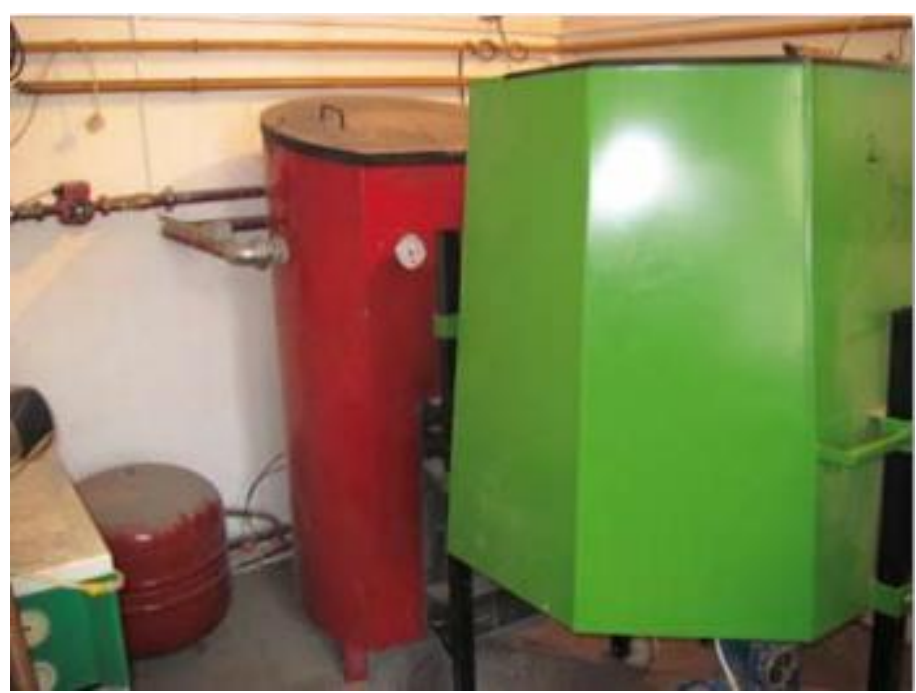

The project was financed through an ESCO system. The whole cost was $120.000 €$, while annual savings come to $35.000 € /$ year.

A further development of the village is to produce her own biofuel.

\subsection{Input data}

\section{LOCATION}

Village: Bercel

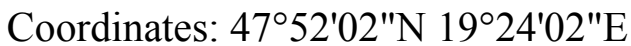

\section{ENERGY NEEDS}

A $100 \mathrm{~kW}$ furnace can be found in the school building

5 furnaces $(50-50 \mathrm{~kW})$ are in the other buildings

A day one $50 \mathrm{~kW}$ furnace uses approximately $180 \mathrm{~kg}$ of woodchips

\subsection{Considerations for the study}

- The municipality wants to produce her own biofuel in the form of energy plantations

- Calculate the needed amount of land to supply local needs

- Offer some plants to satisfy local energy needs

- Include the costs of buying machinery 
- The cost of the installation shall be calculated by the student based on the ratios indicated in the course syllabus

- Bercel is located in a cohesion region, so EU subsidy is available for such purposes 


\title{
MODULE 3: BIOMASS ENERGY
}

CHAPTER 5. Proposed case studies

Subchapter 5.9 - Case Study 9

Dr. Zsolt Radics, Dr. Csaba Patkós

\author{
GEOLIN
}




\section{CASE STUDY 9}

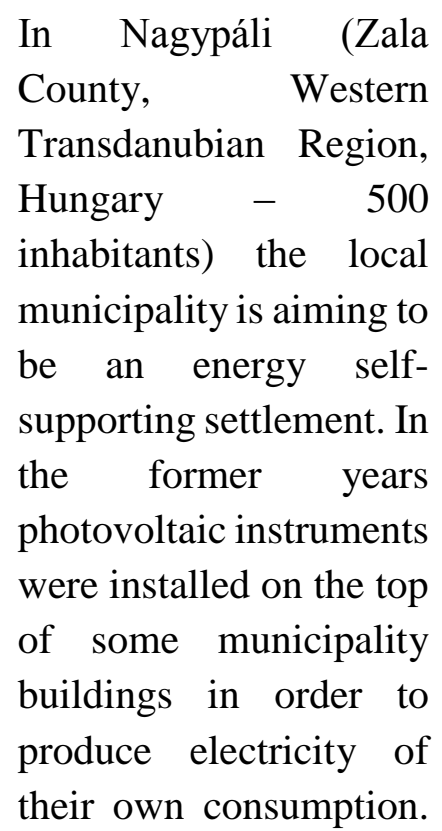

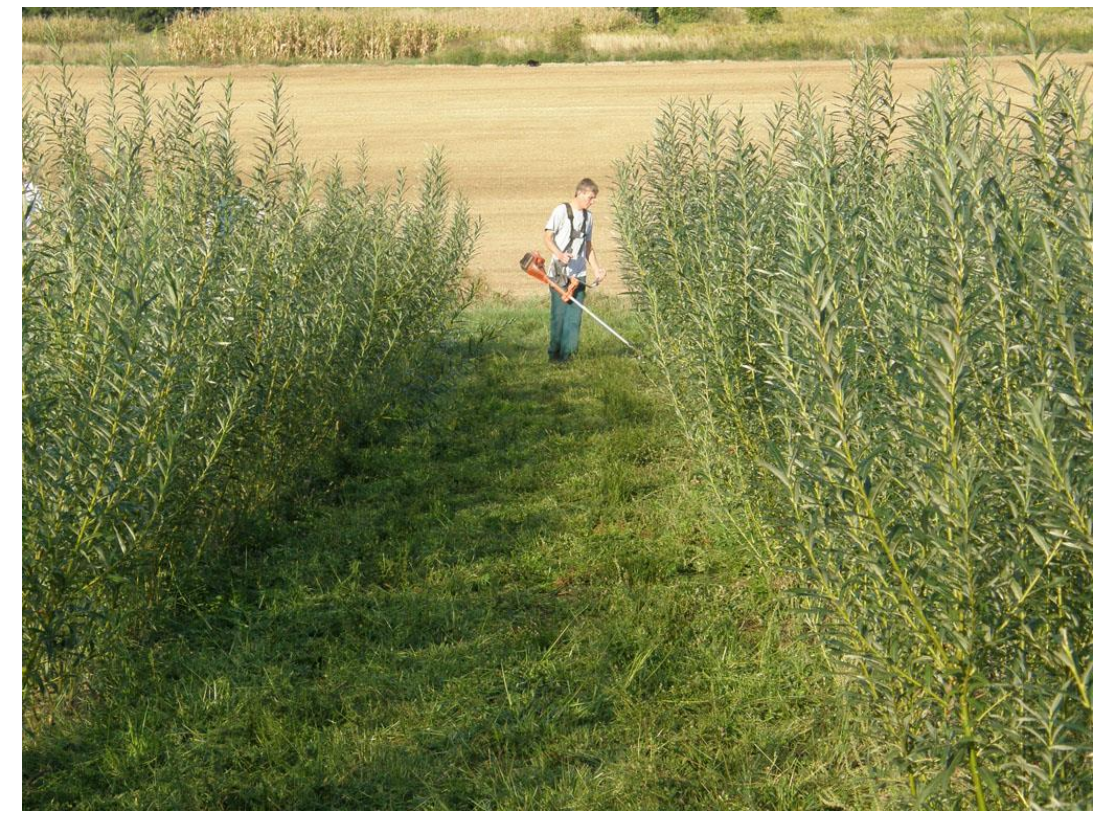
the surplus were sold to the national electricity grid. The community wants to use some parts of local land to produce basket willow (Salix viminalis) as well. From energy plant lands some woodchips will be produced. Woodchips could be used to heat public buildings in the village and surplus could be sold on the market

\subsection{Input data}

\section{$\underline{\text { LOCATION }}$}

Village: Nagypáli, Hungary

Coordinates: 465' $31 " \mathrm{~N} \mathrm{16} 50^{\circ} 29^{\prime \prime} \mathrm{E}$

\section{ADDITIONAL INFO}

The basket willow will be planted in an area of 2 acres, totally 40.000 stools are set.

Each specimen grows until 2,5-3 metres.

Its heating value is approximately $20,5 \mathrm{MJ} / \mathrm{kg}$.

The price of a stool is about 8 cents.

The plant can be harvested manually or by tractors - machinery is available at the settlement

Basket willow can be produced in 2-3 and in 4-6 cutting cycles as well

The market price of the product (in raw and wet condition) is cc. $30 € / \mathrm{t}$

The average yield is 50-60 t/acres annually (in raw)

"The European Commission support for the production of this publication does not constitute an endorsement of the contents which reflects the views only of the authors, and the Commission cannot be held responsible for any use which may be made of the information contained therein." 
The EU agricultural policy supports this land use form with a financial grant of $670 €$ /acre

\subsection{Considerations for the study}

- Consider the benefit of this construction for rural development (concerning economic, social and environmental ones)

- Consider the social impacts and the benefit of this construction for the local land owner

- The cost of the project shall be calculated by the student based on the ratios indicated in the course syllabus 


\title{
MODULE 3: BIOMASS ENERGY
}

CHAPTER 5. Proposed case studies

Subchapter 5.10 - Case Study 10

Dr. Zsolt Radics, Dr. Csaba Patkós

\author{
GEOLIN
}




\section{CASE STUDY 10}

The heating system of a $100 \mathrm{~m} 2$ family house in Tiszaföldvár, North Great Plain Region, Hungary should be transferred from a natural gas-based central heating to a pellet-fed furnace system. The house was built in the 1970s, it is without modern insulation. The town is located in the middle of an agricultural region, additionally some forestry activities are present there as well. Natural gas prices are on the rise. The house is inhabited by elderly people so automatization is a relevant issue.

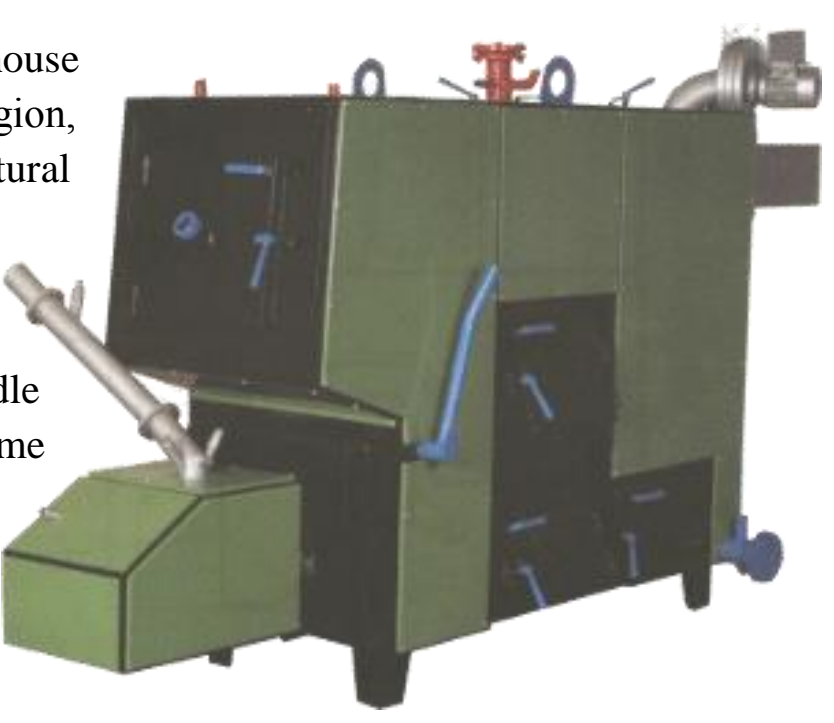

\subsection{Input data}

\section{$\underline{\text { LOCATION }}$}

Town: Tiszaföldvár

Coordinates: $46^{\circ} 58^{\prime} 26^{\prime}$ ' North

$20^{\circ} 15^{\prime} 14^{\prime \prime}$ East

\section{$\underline{\text { ADDITIONAL INFO }}$}

The annual heat energy need is $10.000 \mathrm{kWh}$

Annual cost of heating in case of natural gas furnace $670 €$

Cost of energy production in case of pellet-feeding: cc. $0,01 € / \mathrm{MJ}$

There are enough place around the house for storage

\subsection{Considerations for the study}

- A $15-20 \mathrm{~kW}$ pellet-fed furnace should be used (net price cc.1500 €)

- Size of spooler is about $25-501 / \mathrm{kW}$ (pending on the capacity of the furnace)

- Price of additional component for the system is about the same as the furnace's cost

- Costs of installation: $350 €$

- Energy content of the fuel: $19 \mathrm{MJ} / \mathrm{kg}$

- Price of pellet: $0,3 € / \mathrm{kg}$ 
- The cost of the operation shall be calculated by the student based on the ratios indicated in the course syllabus

- As the settlement is situated in a cohesion region, there are some EU financial support schemes available even for natural persons 
